\title{
HIP HOP CULTURE'S OGs: A NARRATIVE INQUIRY INTO THE INTERSECTION OF HIP HOP CULTURE, BLACK MALES AND THEIR SCHOOLING EXPERIENCES
}

\author{
A Dissertation \\ presented to \\ The Faculty of the Graduate School \\ at the University of Missouri-Columbia \\ In Partial Fulfillment \\ of the Requirements for the Degree \\ Doctor of Education \\ by \\ IAN P. BUCHANAN \\ Dr. Peggy Placier, Dissertation Supervisor
}

MAY 2013 
(C) Copyright by Ian P. Buchanan 2013

All Rights Reserved 
The undersigned, appointed by the dean of the Graduate School, have examined the dissertation entitled

\section{HIP HOP CULTURE'S OGs: A NARRATIVE INQUIRY INTO THE INTERSECTION} OF HIP HOP CULTURE, BLACK MALES AND THEIR SCHOOLING

\section{EXPERIENCES}

presented by Ian P. Buchanan,

a candidate for the degree of doctor of education, and hereby certify that, in their opinion, it is worthy of acceptance.

Professor Peggy Placier

Professor Noelle W. Arnold

Professor Ty-Ron M. O. Douglas

Professor Juanita M. Simmons 


\section{Dedication}

First, I must thank the Most High for giving me the blessings and gifts that I have. There is not enough ink in the world, there are not enough words in all the languages in the world and there will never enough time on a clock for me to express how grateful I am for His guiding hand. While the Most High has intervened in my life in direct ways, he has also placed a number of "angels" in my path, and they have loved, supported, challenged, inspired and taught me.

The five queens in my life are absolute angels. In chronological age, they are Grandmother, Momma, Netra, Carmen and Nia. Grandmother, you are graciousness, love, beauty and faith - all rolled into one feisty, natural hair-sportin', choir-singin' woman. I will always treasure our times.

Momma, you are the reason I am the man I am today. There is not a person alive who is as loving, as committed and as selfless as you. You are my first teacher, and you have taught me wonderful life lessons: put Allah first, be a responsible father and husband, make a difference in the lives of our people and understand that I am one of Allah's many vessels. I am the "fruit" from your tree, and I am blessed to be touched by someone so chosen.

Netra, you have been a best friend and sister to me, and we have a bond that has never wavered. We have been each other's support system, confidante, motivator and encourager for a long time now. You are an inspirational woman in so many ways. Look at God's work...

Carmen, you are my backbone. It is so hard to believe that God made something so wonderful, so beautiful, so loving, so supportive and so "Christ-like" - and allowed 
that jewel to be my wife. You have seen me through this dissertation process... and through some of the most difficult times in my life. I could never repay you for all you have done and been. Thanks for being a "ride or die" wife!

Nia, you are the real inspiration behind all that I do. I am just one person in a long lineage of your family members who try to model what it means to put God and family first. I thank the Most High for allowing me to be his vessel. The baton is yours now. It's your time. Realize your purpose. God has a plan.

There are a number of family members who deserve acknowledgement as well, particularly all of my siblings. I love all of you without bounds. Both of my fathers have provided me with unconditional love, discipline, and general "game." You have given me the tools to stand straight and proudly represent what it means to be a family-centered, joy-bringing, faithful servant. I give the ultimate respect to the true OGs. HT and Brother Ralph, I give you much love and respect. Steel sharpens steel!

Finally, I'd like to thank my research participants. The impact you have had on my life is immeasurable. I appreciate your honesty, vulnerability and depth of knowledge as it relates to the research. Thank you for representing hip hop culture - and thank you for the innumerable ways you have inspired me. 


\section{Acknowledgements}

The doctoral journey has been a test of character, discipline, priorities and leadership. Through the process, I have learned a lot about my passions, my skills and my limitations. I have also discovered that I am obsessed with internet music stations, Beats headphones, dual computer screens and lemonade. Together, they have served me well through the dissertation process.

I would like to thank my outstanding dissertation chair, Dr. Peggy Placier, for being supportive and honest. I appreciate your belief in me. Dr. Simmons, thank you for playing a vital role in my matriculation through the program. I also thank you for pushing my thinking and my writing. My work would not have been the same without your hands, heart and brain. Dr. Arnold, you have been in my corner throughout the entire process, and I appreciate that very much. I hope that our paths continue to cross. Dr. Douglas, thanks for making solid contributions and suggestions during my defense. Continue to carry the torch for black male professors at Mizzou. You are supported by a strong legacy.

Finally, I would like to acknowledge: Monique Kyles, Harvey (Laqweda) Taylor, Jr., Shonda Isaac, Demarko (Brigid) Taylor, Aliyah (Steven) Muhammad, Karriem Muhammad and the Nupes. 


\section{Table of Contents}

$\begin{array}{ll}\text { Acknowledgments } & \text { ii }\end{array}$

List of Tables $\quad$ vi

Abstract vii

CHAPTER 1. INTRODUCTION 1

Background of the Study 1

$\begin{array}{ll}\text { Statement of the Problem } & 28\end{array}$

Research Purpose $\quad 35$

Research Questions 36

$\begin{array}{ll}\text { Theoretical Framework } & 37\end{array}$

$\begin{array}{ll}\text { Design for the Study } & 38\end{array}$

Significance of the Study $\quad 39$

Definition of Terms $\quad 40$

Organization of the Remainder of the Study 44

CHAPTER 2. LITERATURE REVIEW 45

Introduction $\quad 45$

Hip Hop Culture: The Beginnings $\quad 46$

Hip Hop Culture’s National and International Outreach 57

Hip Hop as A Movement Committed to Social Critique and Change 58

Troubling Narratives of Black Masculinity in Hip Hop Culture 62

Limited Research on Hip Hop Culture in Schools 64

Critical/Antiracist Pedagogy in Schools: The Research 71

Culturally Relevant/Responsive Pedagogy in Schools: The Research 76 
Hip Hop in Extracurriculars and Therapeutic Interventions: The Research 79

Summary: Hip Hop Culture - History and Educational Research 81

$\begin{array}{ll}\text { Critical Race Theory } & 81\end{array}$

The Counterstory: A CRT Artifact 83

$\begin{array}{ll}\text { Conclusion } & 85\end{array}$

CHAPTER 3. DESIGN AND METHODS 86

$\begin{array}{ll}\text { Introduction } & 86\end{array}$

$\begin{array}{ll}\text { Statement of the Problem } & 87\end{array}$

$\begin{array}{ll}\text { Research Questions } & 89\end{array}$

$\begin{array}{ll}\text { Research Methodology } & 90\end{array}$

Research Design $\quad 92$

Population and Sampling Procedures $\quad 96$

Ethical Considerations, Consent and Confidentiality 95

$\begin{array}{ll}\text { Data Collection } & 97\end{array}$

Data Analysis $\quad 99$

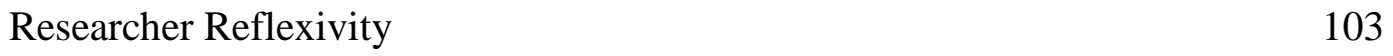

$\begin{array}{ll}\text { CHAPTER 4. FINDINGS } & 106\end{array}$

$\begin{array}{ll}\text { Introduction } & 106\end{array}$

Welcome to the Museum of Hip Hop Culture: The Story Begins 107

The OGs’ Aspirations for Hip Hop Culture $\quad 112$

Critical Analysis of Hip Hop Culture $\quad 115$

Further Exploration of Hip Hop Culture and Masculinity: The OG 124

$\begin{array}{lr}\text { Hip Hop Culture’s Capital Summarized } & 128\end{array}$ 
The Schooling Experiences of the OGs

Conclusion

CHAPTER 5. DISCUSSION

Summary of the Study

Further Connections: The Literature and the Findings

Implications of the Research Study

Limitations of the Study

Recommendations for Further Study

Conclusion 


\section{List of Tables}

Table 1. Progressive Principles of Exemplary Black Male Leadership

Table 2. Problematic Lessons of Black Male Leadership

Table 3. Platform of the Universal Zulu Nation

Table 4. Hip Hop Action Network Platform

Table 5. Antiracist Actions in Three Areas of Schooling

Table 6. Research Participant Information

Table 7. Focus Group Guiding Questions/Statements

Table 8. Books from the Literacy Lineage of the OGs

Table 9. Antiracist Actions in Three Areas of Schooling

Table 10. Archetypes that Connect Boys to Literacy

Table 11. Congruence between Brozo and the OGs 


\begin{abstract}
Using a critical race lens, this narrative study employs a focus group design to explore the intersections between black males, hip hop culture and schooling experiences. To provide a sociocultural grounding, this study first reviews the research literature around hip hop culture's sociocultural development and its impact as a culture force that contributes to both dominant narratives and counter narratives around black male students in the hip hop generation. This overarching purpose of the research study is to explore the ways that black males' engagement with hip hop culture might inform liberatory educational outcomes. Using the composite counterstorytelling methodology, this research study synthesizes the participants' experiences and perspectives around the intersections black masculinity, schooling and hip hop culture. Finally, as it relates to schooling and school leadership, this research outlines the possible implications and recommendations that emerge from the findings. One of the primary implications of this research is that it can inform culturally responsive and antiracist pedagogies that lead to increased self and community agency for boys of color.
\end{abstract}




\section{CHAPTER 1 \\ INTRODUCTION}

\section{Background of the Study}

Over 100 years ago, W.E.B. Du Bois, one of Harvard University's first black

$\mathrm{Ph} . \mathrm{D}$. graduates, painted a vivid picture of the unresolved conflict, contradiction and inner turmoil that would help define the black man's experience and identity development in the United States. In The Souls of Black Folks, first published in 1903, Du Bois suggests that the black male's experience in America is "a longing to attain selfconscious manhood, to emerge from his double self into a better and truer self" (1970, p. 2). In Souls, Du Bois further spells out the black man's dilemma:

After the Egyptian and Indian, the Greek and Roman, the Teuton and Mongolian, the Negro is a sort of seventh son, born with a veil, and gifted with second-sight in this American world - a world which yields him no true self-consciousness, but only lets him see himself through the revelation of the other world. It is a peculiar sensation, this double-consciousness, this sense of always looking at one's self through the eyes of others, of measuring one's soul by the tape of a world that looks on in amused contempt and pity. One ever feels his two-ness, - an American, a Negro; two souls, two thoughts, two unreconciled strivings; two warring ideals in one dark body, whose dogged strength alone keeps it from being torn asunder (1970, p. 2).

When deconstructed, this often-cited excerpt provides an exegesis of the black man's experience in the United States. From the Du Bois quote, a number of broad themes emerge. For the purposes of this research, however, the most telling and insightful parts 
of the excerpt are the interrelated themes of identity conflict and double consciousness. As Du Bois alludes to, as a residual of race-gender oppression in this country, black men tend to embrace the dominant racial group's worldviews and orientations to both gauge and define their humanity and self-worth. French psychologist Franz Fanon supports DuBois' position. In what he describes as a clinical study, psychologist Franz Fanon, in Black Skin, White Masks (1967) goes even further when describing the black man's dilemma, suggesting that the conflict and confusion black men experience is related to their internalized obsession with being white men. First, he suggests that black men have developed an inferiority complex. In Black Skin, Fanon (1967, p. 11) posits, "If there is an inferiority complex, it is the outcome of a double process: primarily economic; subsequently causing the internalization - or, better, the epidermalization - of this inferiority" (p.11). Fanon also suggests that black men want to prove to the dominant racial groups that they have value and worth in society. Fanon describes this "massive psychoexistential complex" (1967, p. 12) matter of factly, suggesting, "Black men want to prove to white men, at all costs, the richness of their thought, the equal value of their intellect" (p. 10).

Both Paulo Freire (1970) and Fanon (1967) suggest that the phenomenon of measuring one's worth by the oppressor's standards is not unique to black males, but is endemic to dominant/subordinate relationships in general. As Freire suggests in Pedagogy of the Oppressed, being an oppressor becomes a model for the oppressed. As he states, "For them, to be men is to be oppressors. This is their model of humanity" (1970, p. 45). Fanon (1967) states that the phenomenon is common among, "...every 
colonized people - in other words, every people in whose soul an inferiority complex has been created by the death and burial of its local cultural originality...” (p. 18).

While the concepts of identity conflict and double consciousness might seem abstruse to those outside of the demographic to which DuBois and Fanon refer, for me, as a black male in the hip hop generation, these themes seem all too familiar. The themes of internal conflict and identity confusion play out in some black men in two general ways. One way is the pernicious, self-injurious phenomenon of self-oppression. For the purposes of this research, self-oppression refers to a broad range of mindsets and actions that are demonstrably harmful, turning one against his/her own racial or cultural group. Below, Freire (1970, p. 62) describes the phenomenon of self-oppression:

Submerged in reality, the oppressed can not clearly see the "order" which serves the interests of the oppressors whose image they have internalized. Chafing under the restrictions of this order, they manifest a type of horizontal violence, striking out their own comrades for the pettiest reasons.

While self-oppression is one response to the racial oppression, another response has agency and self - determination as its outcomes. This response is emancipatory, selfactualizing and status quo - interrupting. Undergirding this response is a belief that oppressive situations can be upended. As Freire (1970, p. 34) suggests, for the oppressed to be able to engage in struggle for their liberation, they must, "perceive the reality of oppression not as a closed world from which there is no exit, but as a limiting situation which they can transform." Dr. Martin Luther King, Jr. (1963, p. 25) describes this agency orientation as well, stating, “As my sufferings mounted I soon realized that there were two ways in which I could respond to my situation -- either to react with bitterness 
or seek to transform the suffering into a creative force. I decided to follow the latter course." King also shows a keen understanding of the role of the oppressed in driving their own emancipation in the 1963 Letter from Birmingham City Jail. Behind Birmingham jail walls, King writes, "We know through painful experience that freedom is never voluntarily given by the oppressor; it must be demanded by the oppressed" (1963, p. 22).

\section{Defining and Exploring Narratives around Black Males}

The double-edged sword of double consciousness and identity confusion, as illuminated by DuBois, Fanon and Freire, gels to produce a set of explanative narratives around black manhood. This research places these narratives into two broad categories: master narratives (also referred to as dominant narratives/discourses) and counter

narratives. While master narratives limit the humanity and agency of marginalized groups, they also create a hegemony that solidifies and naturalizes Others' subordinate position in dominant society (Freire, 1970). Opposing narratives, called counter narratives, challenge structural asymmetries, mindsets and behaviors that support the marginalization of Others. In the paragraphs below, I will further define the concepts of master narrative and counter narrative and also locate the concepts within the context of the black males' schooling experiences.

Following the discussion of narratives around black manhood, I will tell my personal story of self, including discussions of the ways my behaviors, mindsets and actions - both within and outside of school walls - align me with both the troubling master narratives and the more empowering counter narratives surrounding black males 
in the hip hop generation. The identity schizophrenia to which Du Bois and Fanon refer has been a part of my life - for almost all of my life.

Again, a master narrative is a compilation of ideas, mindsets and practices that become mythicized, unquestioned, unexamined truths. These master narratives normalize asymmetries that exist across lines of difference (Tatum, 1997; Freire, 1970). That is, master narratives support hegemony, legitimizing the perpetuation of a status quo that (sometimes inadvertently) supports the existence of dominant and subordinate racial groups. Master narratives create a hegemony that opiates populations and makes those who challenge hegemonic structures appear abnormal (Freire, 1970; Woodson, 1990). Both dominant and subordinate groups perpetuate master narratives but in very different ways.

While the research (Freire, 1970; Donson, 1990) points to ways that both subordinate and dominant groups play a role in perpetuating troubling master narratives that naturalize inequitable social orders, African-American scholar and cultural critic Kephra Burns specifically calls out black males in the hip hop generation, suggesting that they play a significant role in creating troubling master narratives. In an interview with Michael Eric Dyson, Kephra Burns states (as cited in Dyson, 2001), “Thanks to music videos, the image people all over the world now have of African-Americans is of violence-prone, misogynists, preoccupied with promiscuity sex and conspicuous consumption. Despite years of striving to distance ourselves from the negative ways in which white folk once portrayed us, we have come to the point of portraying ourselves to the world in this way" (p. 111). In the same interview (as cited in Dyson, 2001), he also 
refers to Tupac Shakur, an iconic archetype of black masculinity and inimitable cult hero in many hip hop communities, as a person full of "discord, death, and revenge" (p. 112).

Indeed, Burns is not the only African-American that has taken the torch carriers of hip hop culture - black males - to task for interrupting their own liberation and contributing to the troubling master narratives around hip hop culture. Noted author and pastor T.D. Jakes takes the critique of black men in the hip hop generation a step further, spelling out the unintended consequences of positioning hip hop artists as role models and community leaders. Jakes states, "My fear is that in the absence of strong unity in our community, these entertaining voices have been mistaken for the messiahs of a generation who has lost their way and desperately needs a compass that directs them beyond a lyric that excites them" (in Dyson, 2006, p. 208).

While Burns and Jakes highlight a pernicious master narrative and its dangerous implications for the hip hop generation, researcher Stinson (2008) and Ogbu (1992) focus on the narratives around black males and schooling. In the research article "Negotiating Sociocultural Discourses: The Counter-Storytelling of Academically and Mathematically Successful African American Male Students," researcher David Stinson (2008) sorts the master narratives around black males into distinct but interrelated categories. John Ogbu, in the research article entitled "Understanding Cultural Diversity and Learning" (1992) also buckets the narratives around black male achievement. The researchers suggest that black males in the hip hop generation encounter these narratives - in a variety of iterations and at various times - throughout their schooling experience. They are described below. 
Black males as permanently-deficited underperformer. This master narrative mythicizes and naturalizes the achievement differential between black male students and their counterparts. This narrative suggests that white males set the bar for academic achievement and black males will continue to lag behind (Stinson, 2008), despite Herculean efforts to challenge this achievement gap. Researcher John Ogbu outlines the discourses that attempt to explain or naturalize black male underperformance, highlighting perceived cultural, schooling and experiential shortcomings of black students. John Ogbu (2008) articulates three dominant discourses that purport to explain (and even justify) the black/white achievement differential. The cultural deprivation argument suggests that black students' culturally-deprived homes and neighborhoods are to blame for underachievement. The cultural conflict argument suggests that blacks have a defined culture, but, it is deviant and clashes with the normative white, middle class cultural norms of schools. Finally, the hereditary deficiency argument posits that hereditary differences among the races contribute to black underachievement.

Binary black male as caricature. This constructed black male master narrative places black males into caricatured, narrowly defined archetypes. For the black male collegians in Stinson's study (2008), the archetype is defined as “...the jewelry-donned, baggy-clothed, player 'thug' who projected a nonchalant attitude toward school and academics" (Stinson, 2008, p. 991). This discourse provides a limiting, either/or, highly racialized definition of authentic black maleness. The dominant discourses around race tend to place black and white boys in divergent, immutable categories, naturalizing both black inferiority and white superiority. To be a black male is to be an anti-intellectual, 
school-phobic thug and to be white male is to function subconsciously as if one's position of power is a result of innate, unquestionable superiority and hard work (Stinson, 2008).

To summarize, the master narratives around black males in the hip hop generation suggests that they are violence-prone, misogynistic self-oppressors who will continue to lag behind their counterparts because of cultural, community, or personal deficits. However, there is a fundamentally divergent perspective around black males in the hip hop generation. There is a counter narrative to the troubling master narratives that cloaks black males in the hip hop generation.

As discussed previously, a counter narrative attempts to challenge and disrupt worldviews, actions and mindsets that consciously or unconsciously support systemic marginalization of historically oppressed groups. The counter narrative can create a dissonance that challenges the dominant racial group's ethnocentric view of truth and knowledge (Delgado, 1995). Without the counter narrative, argue Ladson-Billings and Tate (1995, p. 58), "Oppression is rationalized, causing little self-examination by the oppressor.”

For black males in the hip hop generation, one who represents the counter narrative challenges notions of black underperformance and the permanency of an achievement gap. Urban Prep Academy, a predominantly black high school in Chicago, is an exemplar of an educational institution that challenges the dominant narratives around black male underperformance. As indicated on the school's website (Urban Prep Academies, 2013), “For the third year in a row, 100\% of Urban Prep's graduates has been accepted to over 128 different colleges and universities throughout the nation."

A black male in the hip hop generation who represents the counter narrative resists the notion that thugism, violence, misogyny and anti-intellectualism are normative 
for his generation. A black male representing the counter narrative resists the narrative of black masculinity that suggests that their humanity is tied to their ability to objectify or subjugate others. As I student and citizen, I have engaged in actions and have developed mindsets and have executed actions that align with both master narratives and counter narratives,

\section{My Story: Can Anything Good Come Out of East St. Louis?}

Indeed, Du Bois' 100 year-old excerpt resonates with me in a profound way. It is as if Du Bois had a voyeuristic peek into $m y$ life when he spoke of the dual-consciousness and identity confusion that cling to black males. While Du Bois' words highlight the multiple complexities of my experiences as a black man, my personal experiences and interaction with other black males in the hip hop generation, along with my research, strongly suggest that I am not alone.

The concepts of master and counter narrative illustrate a type of collective doubleconsciousness of in the lives of black males. The story I tell of my life highlights my experiences as a black male, a member of the hip hop generation, a child of poverty and as a graduate of a predominantly white university. These parts of my life bear some congruency to some of the aforementioned master narratives about black males. My research suggests that feelings of conflict, dual consciousness and alienation permeate the souls of many of us - black males who identify as being part of the hip hop generation. Though black males trek through the halls of P-20 schools, our collective voices have been largely absent from educational reform conversations, despite the fact that our underperformance in P-12 schools and in colleges suggests a need for reform, overhaul or a combination of both. As historically marginalized groups' experiences and personal 
theories related to education must be situated within a sociocultural context, both within and outside of schools, my personal story begins in one of the poorest, most violent, infrastructurally-challenged small communities in the country. My story begins in East St. Louis, Illinois, a city that state government officials once referred to as "the most distressed small city in America" (as cited in Kozol, 1991).

My hometown of E. St. Louis, Illinois, has been called “...simply the worst possible place I can imagine to have a child brought up" ("State Superintendent and Chairman," 1989). The statement is an exemplar of the dominant discourse around those who grow up in impoverished, crime-ridden neighborhoods. This master narrative describing certain cities and those who live in those cities is informed equally by a combination of media hyperbole and material realities. I offer a recent Saturday Night Live skit in April of 2012 as an example. In the skit, the impersonator of presidential candidate Governor Mitt Romney says, in a press conference, that East St. Louis "feels like home" (Michaels, 2012). Presumably because of the master narrative surrounding E. St. Louis, the live crowd erupts in laughter at the Romney impersonator's statement. East St. Louis' mayor impersonator, standing directly behind the Romney impersonator in the press conference skit, looks at the Romney character strangely and responds forcefully that East St. Louis is a "hellhole" (Michaels, 2012). Again, the live crowd erupts in laughter. Later in the skit, the mayor impersonator makes his point even more convincingly, saying, "I'm the mayor. This place is a hellhole" (Michaels, 2012).

The narrative offered by Saturday Night Live suggests that East St. Louis is a virtually uninhabitable place that even its own residents and leaders are desperate to escape. Similarly, Jonathan Kozol, whose seminal research is captured in the book 
Savage Inequalities (1991), provides a horribly bleak narrative of East St. Louis as well. Coincidentally, Kozol began his exploration of East St. Louis in 1988, one year after I had graduated from one of the schools Kozol researched. I lived in the communities Kozol researched and still spend time in some of those communities. Students in my generation who share my racial background and a set of similar schooling and community experiences were part of Kozol's study.

The story Kozol paints of my native city contributes to a master narratives of East St. Louis that says that it is a hopeless city from which no good can come. First, in his book, Kozol posits that living in East St. Louis is essentially a death wish for black males. Kozol (1991) states:

The decimation of the men within the population is quite near total. Four of five births in East St. Louis are to single mothers. Where to men go? Some to prison. Some to the military. Many to an early death. Dozens of men are living in the streets or sleeping in small, isolated camps behind the burnt-out buildings. There are several of these camps. (p. 15).

In addition to pointing out the dismal outlook for black men in the community, Kozol also formulates his narrative by highlighting infrastructure challenges, healthcare crises and concerns about crime.

Like the Saturday Night Live skit, Kozol's work constructs a bleak narrative around East St. Louis. That is, East St. Louis, the backwash of American society, will never pull itself out of its morass and should be avoided at all costs. To drive the point home, Kozol (1991, p. 25) says in his book, "There is no natural way that East St. Louis can bring itself out of this situation." He also says, 
East St. Louis will likely be left just as it is for a good many years to come: a scar of sorts, an ugly metaphor of filth and overspill and chemical effusions, a place for blacks to live and die within, a place for other people to avoid when they are heading for St. Louis (Kozol, 1991, p. 25).

Representing master and counter narratives. Growing up, many of my friends were products of single parent households. Until my mother married my stepfather a few months before my ninth birthday, I was part of a single parent household. My biological parents were high school sweethearts, possibly conceiving me on my mother's prom night. When I was born, father was allegedly visiting a second girlfriend three hours outside of East St. Louis.

My mother Paula, an ethical, family oriented, God-fearing woman, experienced her early childhood years in the Sandra Gray Homes, an East St. Louis housing project, now notorious for violent crime. After living in the Gray housing projects until her preteen years, she, her parents and her four siblings moved to a home on the working class edge of the E. St. Louis community. Her dad, Alvin, worked in the produce section of a local grocer and at a local gas station. Her mother, Tina, babysat her grandchildren and took on home-based business ventures.

My father, Harry (falsely rumored to be the love child of a not-so-secret relationship between my grandmother and a world renowned, then-married rock and roll legend), was raised by his grandparents in comparably well off circumstances. His mother, consumed by work, relationships and depression, left him with his grandparents five days after he was born. Jack Boykins, my father's maternal grandfather, was a respected politician and law enforcement officer. Mattie Boykins, his grandmother, 
worked as a cook in the local school district. While my father lived a life of relative privilege compared to others in his community, his dependence on mood-altering substances would eventually lead to disastrous consequences.

Counter narrative: Not just another male underachiever. From the time I could recall, I always had the inclination to be a leader and a scholar. As a four year old preschooler at Guy's Kiddie Kove, I read more books than any of my classmates, and, because of my academic proclivity, I was allowed to skip kindergarten and go directly to first grade when I left Guy’s. I was also a burgeoning leader at Guy’s Kiddie Kove, serving as the youngest captain of the school's drill team cadre at age five. The trend of leadership and scholarship would continue throughout my educational career. Parts of my life stood in stark contrast to the "East St. Louis can produce nothing good" narrative many times offered by members of the dominant racial group.

At Davis Elementary School, I became the self-proclaimed leader of all of our playground activities. I would methodically organize teams, place my classmates in the appropriate roles and the conceitedly refer to myself as boss. I became the self-appointed captain of both the school basketball and softball teams. In addition, I was honored as a top student each year I attended Davis. An archetype of black masculinity, Davis principal Edward Swinney, was a towering presence in the school and in the community. He challenged me to be, "not the best, but the very best." Since elementary school, Mr. Swinney's words have stuck with me, and I have consciously set out to set high expectations for myself and others in most all that I do. Since elementary school, I have been obsessed with being the very best. 
In junior high school and high school, I attempted to further embrace Mr. Swinney's challenge to strive for excellence and set high expectations for myself. In junior high school, while I excelled in sports, I also became the state vice-president of the National Junior Beta Club (a national honor society) and participated in mathematics contests all across the region as well. In both junior high school and high school, I was the top ranked male and received superlative awards such as "most likely to succeed" and "smartest male." Eventually, my academic success would provide me with the opportunity to choose from several full academic college scholarships. I, along with three of my friends who also received a host of scholarship offers, would choose to attend the University of Missouri-Columbia.

Though there seemed to be a double strand of scholarship and leadership coded into my DNA, I, like many, am also guilty of succumbing to the harsh realities and pressures of urban life. Like many of my hip hop culture-dipped brethren in poor, black communities across the United States, I perpetuated actions that contributed to the negative perceptions of the 'hood as being a least desirable place of residence. More specifically, I represented the troubling caricature of black males that has been promoted in media and in academia. Anti-social behaviors (misogyny, violence and other forms of crime) and alcohol abuse were just as much a part of my life as were academic performance, leadership and sports.

Master narratives: Troubling behaviors. The most vivid examples of my troubling behavior center around (a) my experiences at rock and roll concerts in the mid1980s along with my (b) sometimes-violent, misogynistic actions towards others who shared my racial identity. While dominant value orientations might explain actions the as 
a result of inherent anti-social tendencies or cultural deficits, another perspective might interpret the actions differently. From another, more critical perspective, the actions are exemplars of ways that oppressed groups actualize internalized oppression. That is, an outgrowth of oppressing marginalized groups is violence towards other groups, even those groups with whom they share a common racial background and sociohistorical experiences (Freire, 1970; Woodson, 1990).

My string of rock and roll concert experiences began in the mid-1980s during my sophomore year of high school. Large contingents of my peers would catch the bus and travel across the Mississippi Bridge to St. Louis to catch the hottest rock bands of the 80s. Groups like Van Halen, AC/DC, Krokus and Twisted Sister embodied a coolness that we found to be magnetizing. Being black and occupying a space typically reserved for young white rock and roll lovers did not deter us from attending these concerts. Neither did it prevent some of us from engaging in some heinous crimes against white folks.

On a warm day in September of 1985, two of my friends and I purchased tickets to see the rock band Judas Priest. As I rode the bus across the Mississippi River to downtown St. Louis, I knew that, once I got off the bus and into the concert, I had to perform an action that would give me a level of street credibility among my black rocker peers but would be in contrast to my ethical home training. I would succumb to peer pressure and perform an action that supported the "black man as perpetuator of violence" narrative. I would execute this troubling action with perfection.

As my friend and I left the concert, walking towards the bus station, I saw a young white woman leave the concert. Little did she know, she would be our first victim of the night. As she walked into a dimly lit parking lot immediately outside of the concert 
venue, my friend and I quickly ran behind her. In a series of quick moves, my friend hit the woman with a hard metal object, and I then snatched her purse and concert t-shirt. My goal was accomplished. I passed the test. I was able to go to school the next day and sport the t-shirt I'd violently taken from an innocent, unsuspecting person. I was now considered hard. I was a tough guy. I had my t-shirt to prove it.

Not only did I contribute to the master narratives around East St. Louis (and around black men in general) by being violent towards those outside of my race (the man), but I also victimized people with whom I share a racial background. I inhaled the smog of racism and belched it out in the form of internalized oppression. In college, I was both misogynistic and violent towards women who shared the racial background of my daughter, my mother and my grandmother - women whom I love and respect.

As a college student, my behaviors suggested that I bought into a narrative that black women had a lesser value than men and should not always be treated with respect and deference. As a college freshman, manipulating women and juggling multiple relationships was a badge of honor. I was a playa - a womanizer, a man who misled women to think that he was exclusive although he was dating and having relationships with multiple women. As a playa, I was not only dishonest and disrespectful towards black women, but I also successfully encouraged them to be violently antagonistic towards each other. I was a proud and willing participant in the oppression of black women.

My misogynistic ways came to a head on two separate occasions. First, two women that I dated simultaneously found out about each other. Upon realizing that they both were dating me, they bumped into each other on campus and began arguing. Very 
quickly, a verbal conflict became violent. Fighting in front of the main campus library, both women sustained physical injuries and had to be seen by a medical professional. While this incident stroked my vanity and made me feel more like a virile man, it is indicative of how a black man can play a role in negatively impacting the lives of those who share his racial background and historical experience of race-based discrimination.

This second example of my misogynistic actions is equally as disturbing, and it too demonstrates how my actions sometimes align with the troubling narratives around black men in the hip hop generation. On a Saturday in October of 1988, I was initiated into a highly selective fraternal organization and was celebrating at a happy hour venue by enjoying food and drinks with my girlfriend and her sorority sisters. Unfortunately, as the night progressed, I drank to the point of extreme inebriation and began to argue with my girlfriend. In my drunken stupor, I escalated the argument and became physical with her. When I sobered up the next morning, I realized that I had left my girlfriend with some serious physical and emotional injuries.

The role of black male role models. While the above snapshots of my life experiences plant me squarely in alignment with the master narratives, a number of countervailing factors pulled me forcefully in a different direction. These countervailing factors have afforded me with a worldview, a set of experiences and number of accomplishments that challenge dominant narratives around East St. Louis, black men, and the hip hop generation en masse. Of all of the countervailing factors that allow me to represent a counter narrative, the omnipresence of a diverse group of black males is most significant. In my religious life, on the sports field and in my schooling experiences, black male role models were always present and positively impactful. 
Religion and spirituality. My religious life experiences begin and end in the Nation of Islam, led by the Honorable Minister Louis Farrakhan. My mother joined the Nation of Islam a few months prior to my ninth birthday. She then married my stepfather, Ronald Muhammad, soon after joining the Nation. Through the black men in the Nation of Islam, I learned lessons of black pride, living by very strict moral parameters and having an unshakable belief that I am part of Allah's chosen group - the group that will take over the Earth in days of Armageddon. Throughout my life, I witnessed Louis Farrakhan and the Nation of Islam do what is set out to do - use a strict religious platform transform black men, women, and families. I witnessed and experienced the master narrative-to-counter narrative transformation that Minister Farrakhan almost singlehandedly fomented. I was inspired and encouraged.

I first met the Honorable Minister Louis Farrakhan backstage after a lecture in 1978 at Southern Illinois University-Edwardsville. Immediately, I was captured by Farrakhan's welcoming and nurturing disposition. For me, Farrakhan represented black masculinity at its apex. His fair skin, perfect coiffure, impeccable fashion sense and penchant for scholarship simultaneously complemented and contradicted the fiery, no nonsense and justifiably-angry disposition. These two seemingly divergent sets of dispositions, along with allegiance to living a life guided by the Most High Allah, resonated with many black men and made him a venerable every man's man, an archetype of black masculinity - at least in my eyes.

Not only did the Minister represent black masculinity for me, but so did the Fruit of Islam (FOI), the Minister's paramilitary security group. A contingent of disciplined, no-nonsense black men, the FOI projected fearlessness and a commitment to defending 
the humanity and respect of blacks across the Diaspora. More specifically, the FOI considered black women to be Allah's precious jewels, deserving of the utmost respect and deferential treatment. Within the FOI, there were three "brothers" that particularly influenced the trajectory of my life.

First, there was Brother Muhammad Aziz. An articulate and passionate father figure, Brother Aziz first told me that I needed to challenge the narrative around black males and anti-intellectualism. He told me I would be a pediatrician and not a baseball player, my career goal at the time. He said that the white man wanted to black man to be consumed with sport and play instead of building a black nation. When I was 10 years old, Aziz gave me a Muslim name to replace Ian, which he referred to as a slave master's name. I became Brother El-Amin, which means the honest and trustworthy one. Although I have failed many times, I continually strive to live up to the name he granted me. Next, there was Brother Gregory X, a no nonsense third-degree black belt who taught me how to channel my physical force to accomplish what seemed to be monumental feats, like breaking several wooden boards with my bare fist. The overall life lesson he left me and all of my peers with was simple: the force of one's gifts and talents should be used to break down the barriers that lead to the marginalization of blacks in poor communities.

Last, there was Brother Kim X, who had the hairstyle and general swag that I spent hours in the mirror trying to recreate. Not only did Brother Kim have the swag, but he was also one of the few college graduates in the ranks of the FOI. In addition, he was a member of a fraternity that I would later join. In my elementary through high school years, Brother Kim would encourage me to pursue higher education and use the fraternity 
membership as a means to provide mentoring programming to black male youth. I tried to walk in his footsteps the best I could.

Athletics. One of the things the Nation discouraged was participation in organized sports. Despite that prohibition, my parents still allowed me to participate, as they understood sports to be a way to satisfy my competitive energies and to also extend my collegial relationships with my same age peers. As an unintended consequence of my participation in little league baseball, I met J. T. Turner, a man who would teach me transformative life lessons. Mr. Turner so positively impacted my life that I would be a speaker at his funeral.

Very strategically, Mr. Turner named our team the Hustlers, and he explained to us that we were a team of hard working, disciplined ballplayers, oriented towards being successful at any cost. Under Mr. Turner's leadership, the Hustlers, an under resourced and overconfident team from E. St. Louis, would win championships against teams from all parts of the country, including Illinois, Kentucky, Missouri, Texas and Florida. While some consider Mr. Turner a questionable character because he was known to illegally use overage players to give our team an unfair advantage, he was a hero to us. Mr. J.T. Turner helped a group of black males develop resilience, selflessness, work ethic and self-confidence through sports - a rites of passage experience for many black males, including myself and my Hustler teammates.

In both my religious journey and in sports, black males have informed my life experiences in ways that challenge dominant worldviews around black males in my generation, the hip hop generation. Throughout my educational journey as well, black males have made a significant impact in shaping my worldviews and actions - at least the 
ones that challenge master narratives. While the currently reality is that, in public schools, the current concentration of black male teachers is two percent (National Council for Educational Studies, 2012), I was privileged to have an educational experience heavily concentrated by black males, both inside and outside of the classroom. In elementary school and high school, black males positively impacted my self-concept, my self-confidence, my worldview and my subsequent status quo-challenging actions.

Education. At Davis Elementary School, I was immediately captivated by the presence of school principal Edward Swinney. A well-dressed, stern disciplinarian with a Martin Luther King-like passion and vocal cadence, Mr. Swinney - like Minister Farrakhan, the FOI and coach J.T. Turner - was an archetype of black masculinity for me. Mr. Swinney encouraged us to "be not the best, but the very best," specifically challenging the boys to grow up to confront the myths and stereotypes about E. St. Louis. He also promoted the celebration of black culture and heritage through extracurricular programs, academic contests and slogans. Mr. Swinney and the black male teachers on his staff modeled a set of positive possibilities for me and my peers. As a result of the academic foundation and cultural capital I gained from my experiences with black men at Davis, I was able to navigate a number of challenging circumstances throughout my educational journey.

In high school, two teachers and a principal inspired me towards using educational service as a means to expand the life options for black boys. Their modeling helped me to develop the worldview that educational leaders have the potential to change communities in radical ways. Mr. Cole and Mr. Nilsson were both mathematics teachers at Lincoln High School. While Mr. Nilsson was the young teacher phenomenon, the 
veteran Mr. Cole, since the late 70s, was considered one of the top teachers in the school district. In part because of these two gentlemen, I was able to secure full academic scholarships and obtain an undergraduate engineering degree from a selective university. Unlike the majority of my male peers, I had the opportunity to choose between three full scholarships.

In addition, partly because of the teaching duo's modeling and inspiration, I became a mathematics teacher. I consciously added aspects of both men's' stage presence and instructional practices into my teaching tool belt. After teaching for five years, I decided to walk in the shoes of the other black man I highly respected at Lincoln High School, principal John Brown. Principal Brown was a respected member of the E. St. Louis community, known as much for his legacy of Cadillacs and diamond jewelry purchases as he was for leading a group of competent, caring and committed teachers towards producing scholars, athletes, artists and musicians. As a former school principal, I strove to create a culture of high student expectations and black student achievement in many of the ways that my grandmother's brother, Mr. Brown, did.

Leadership lessons learned. Of all the personal experiences, professional trainings and scholarly endeavors that have informed my leadership, the aforementioned black males have been the most significant in molding my leadership profile. Indeed, my leadership, though influenced by hip hop culture, is mainly guided by a set of principles imbued in me by a group of black male role models. This is not to say, however, that some of my role models did not have mindsets or behaviors that supported some of the dominant narratives around black men. Although they were strong men, they were not immune to some of the outgrowths of racial and race-gender inequality. In the summary 
section of this chapter, I summarize the leadership lessons I have taken from them - even those lessons that align with the more dominant, troubling discourses.

First, I will explicitly discuss the progressive leadership principles I have taken from the playbooks of some of my most revered role models. I break them into eight interrelated, guiding principles of exemplary leadership. In no particular order of relevance, they are listed in Table 1 below.

Table 1

Progressive Principles of Exemplary Black Male Leadership

1. Leaders Centralize and Value the Experiences and Cultural Capital of People of Groups on the Margins of Dominant Society. The male leaders that inspired me believed that people of color (specifically black people) have a common set of experiences and cultural norms that must be considered and valued when a leader develops his actions and theories that lead to systemic changes.

2. Leaders Nurture, Support, and Develop Black Males. Leaders who will change the current landscape of racial inequality must make black male development and empowerment a priority.

3. Leaders Challenge Beliefs and Actions that Contribute to Systemic Oppression Across Lines of Difference. Leaders must consistently, actively reject and challenge and actions that deprive others of the ability to self-actualize. Leaders must engage in critical thinking and always consider the way that mindsets and actions foster systemic inequities.

4. Leaders Set High Expectations for Themselves and Others. Not only must leaders set high expectations for themselves and others, but they must also show what high expectations look like. In addition, leaders must also motivate others to believe that challenging goals can be attained.

5. Leaders Must Help Others Develop Resiliency. Along with creating cultures of high expectations, leaders must help others develop the resilience to push for personal and systemic change, despite challenging obstacles. Leaders help others develop a belief that seemingly insurmountable odds can be overcome through hard work, alliances with likeminded others and steadfast faith.

6. Leaders Show Respect and Reverence for Family. My role model leaders taught me that revering and respecting family is crucial to transforming the black community. More specifically, African American women must be respected, protected and revered. A key to transforming the black community is supporting black women in a way that allows them to overcome the structural challenges that limit their full humanity and participation in society.

7. Leaders Have A Primary Responsibility to Help Uplift the Black Community. If I cannot point to concrete ways (besides personal gain) that I have not contributed to change in the black community, I would not consider myself a leader. Leaders must 
define actions and mindsets that support the status quo of inequality based on lines of difference. Then, they must work tirelessly to execute actions that poke holes in the balloon of inequity.

Along with highlighting the progressive leadership principles I have gleaned from a number of black male leadership legends, I must acknowledge and discuss the problematic principles of leadership I have embraced as well. Analogous to the impact of the hidden curriculum in education - the practices and mindsets in education that unintentionally marginalize students along lines of difference - I have also unintentionally embraced leadership mindsets and behaviors that have marginalized and limited the full humanity of others, including myself. While I try hard to resist hegemony, the research mandates that I be forthcoming, reflecting on the lessons I have learned about black masculinity and the role of women that impact my ability to leverage my leadership towards apple cart-upsetting outcomes. The lessons listed below support the dominant narratives, but they inform my leadership as well.

\section{Table 2}

\section{Problematic Lessons of Black Male Leadership}

1. Black Male Leaders Must Embrace the Cool Pose as Part of Their Definition of Masculinity. As articulated by Majors and Billson (1992), the cool pose is a set of psychological and physical dispositions adopted by black men as a hypermasculine response to a system of oppressive conditions.

By acting calm, emotionless, fearless, aloof, and tough, the African American male strives to offset an externally imposed "zero" image. Being cool shows both the dominant culture and himself that he is strong and proud. He is a survivor, in spite of the systemic harm done by the legacy of slavery and the realities of racial oppression (p. 5).

From my experience, a leader who embraces the cool pose typically adopts a hypermasculine stance that marginalizes his gay and bisexual brethren. Most leaders I admire, either explicitly or implicitly have defined black manhood in a way that equates being gay with being a deviant. From them, I have gathered that gay men have no role in the transformation of the black community. More specifically, gay men definitely do not have place in schools, as they do not 
represent the "strong" black male archetype our boys need. Though I embraced the notion of gay male exclusion early in my professional career, I can say that this sentiment is on a page in the black male leadership bible that I have ripped out. I no longer embrace the homophobic notions I once had. In this way, I reject at least one lesson taught to me by my role model leaders.

Also, with regard to the cool pose, a leader who embraces the orientation believes that outward signs of vulnerability are antithetical to strong leadership. As it has been defined for me, a strong black male leader must never show signs of vulnerability, as vulnerability will been seen as weakness - and summarily exploited. Especially in the Nation of Islam, it was articulated that no one should ever see a black man publicly cry, apologize or exhibit any other disposition that does not align with the "man as hard as a rock" archetype. A strong leader should not admit his flaws publicly and should definitely not be seen as anything except all-wise and all-knowing. A real black male leader never shows cracks in his armor.

Again, cool pose-influenced leadership limits the leader's ability to impact status quo-changing actions (Majors and Billson, 1992). Like Freire (1970) suggests, the impact of oppression has a ripple effect on a number of parties, including both the oppressor and the victims of the oppression. The cool pose, a manifestation of racial oppression, limited the impact of the many of the role models who influenced me. As a leader committed to eliminating educational inequality, I must, first, examine how the cool pose limits me and other black male allies. Second, I must work consciously struggle to prevent the cool pose orientation from limiting my efforts to eradicate educational inequality.

2. A Woman's Role is Subordinate. Several of the leaders that informed my leadership orientation have a more chauvinistic view towards women, especially as it relates to a woman's role in leadership. One of the leadership lessons taught to me by my Muslim role models is that women leaders should assume a role behind black men, not in lockstep with us. Those leaders did not see women as an equally-yoked driving force for black liberation. Instead, they saw women as supporters, cheerleaders and executors of the man's leadership game plan. My leadership role models in the Nation respected women's role in leading family (especially children) and other women, but, generally, they did not promote women to the highest positions within the Nation's ranks.

\section{Hip Hop Culture and My Life}

While my worldview, actions and leadership have been influenced both by my upbringing in the challenging but nurturing environment of East St. Louis and the male leaders who served as role models for me, I have also been heavily influenced by hip hop 
music and hip hop culture. Therefore, hip hop culture is the third major element of the study. Throughout the course of my life, hip hop has inspired, explained, taught, disturbed, disgusted and molded me. In the sense that hip hop reflects many elements of my worldview and life experiences, it is the soundtrack to my life. In the sense that hip hop culture voices my anger, discontent and critiques toward an unjust system, it has fueled a resistant, revolutionary fervor in me. Also, in the sense that it articulates and inspires my hopes and dreams, hip hop is just as inspirational as any motivational speech, church service or gospel song. Finally, and most troubling, popular expressions of hip hop culture sometimes take moral positions and articulate mindsets that I want so badly to reject, but regrettably embrace. Hip hop exposes the impact that racism has on me. Although hip hop represents the counter narrative at times, hip hop also emits smog that I have regrettably consumed.

In this study, hip hop culture represents both the master and counter narratives on black masculinity - in one powerful, artistic form. While hip hop culture may arguably have more flaws and troubling narratives than assets and progressive elements, I can appreciate the roses of hip hop but still dislike its thorns. I can situate hip hop culture, its creators and its current baton-bearers in a sociocultural context, understanding that the culture and its owners are part of a system that marginalizes along racial lines. That marginalization produces a harmful pollutant, or smog. In some ways, hip hop is the residue of the smog, and it also embodies the double consciousness and identity conflict that Du Bois and Fanon spoke about. This, by extension, essentially means that hip hop culture reflects who I am. As hip hop emcee Mos Def suggests, on his Black on Black 
Sides album (1999, Track 1), "We are hip hop. Me, you, everybody - we are hip hop. So hip hop is going where we are going."

This research study will explore the schooling experiences of black men like me who consider themselves to be a part of the hip hop generation. For the purposes of this study, a member of the hip hop generation is narrowly defined as:

- One who shares a racial or class background of the culture's originators and primary drivers (i.e., working class and poor blacks and Latinos).

- Those whose pre-teen and teen years were dominated by aspects of hip hop culture, including worldviews, ways of communicating, music, fashion, art, dance and/or scholarship.

Social development theorist Lawrence Kohlberg (1981) refers to the preteen/early teen period the Conventional Morality Period. This is the period in which an individual is more apt to grapple with many of the rules and standards of the group one is most exposed to/interactive with. In essence, the Conventional Morality Period is one in which a person's moral stances and worldviews are most heavily influenced by one's environmental contexts. The research participants in this study were chosen because hip hop culture was the dominant cultural force during their pre-teen/early teen years, or Conventional Morality years. It stands to reason that their worldviews would be significantly influenced by the hip hop culture. That is, hip hop culture is one of the lenses through which the participants in this study read (or make sense of) the world. Hip hop culture is also a way in which individuals write (or externally process) their engagement with the world. 
The overarching purpose of the research is to explore the schooling experiences of a subset of black males who have been part of the largest cultural movement in the last 30 years. This study is also designed to explore the ways that the lens of hip hop culture has informed the worldviews and actions of the participants. Another purpose of the research is to explore ways that the experiences of this group might inform education reform and leadership. Using a Critical Race Theory framework, this research will also examine the extent to which stories of the OGs of hip hop either challenge or support master narratives.

\section{Statement of Problem}

Hip hop culture has been in America's bloodstream for over 30 years; however, the voices of people of color who are a large part of the hip hop generation have been largely marginalized from the discourse on education reform (Irizarry, 2009; Keyes, 2009). Many researchers argue that educational reform cannot take place without privileging the perspectives and cultural capital of those who occupy the margins of society, especially people of color (Gay, 2000; Ladson-Billings, 1997; Hollie, 2001). Researchers also argue that educational reform efforts must consider contextual factors that influence educational outcomes. To that point, William Foster (2004) suggests that, "When we divorce education from other contexts that influence and are influenced by broader context, we limit our ability to develop a deep understanding...Calling for excellence without concurrently analyzing social conditions is simply blowing in the wind" (p. 187).

As legendary hip hop emcee and scholar Chuck D states, hip hop culture, “... for black America, is like our CNN" (as cited in Ridenhour \& Steiner, 2000). That is, hip hop 
culture $i s$ the contextual lens through which many black youth and adults are informed about the world. As Freire (1970) suggests, oppressed people use culture to describe, or read, their world. Hip hop culture, then, is important because it is a way in which a historically marginalized group describes and interprets its reality. As researcher Izzary (2009, p. 511) states, "Understanding hip hop culture gives us insight into the most powerful force in the lives of urban youth and can be used to further engage students instead of marginalizing them." Irizarry (2009) further puts the import of hip hop into perspective when he says, "Although rarely tapped as a resource, urban youth have much to teach us about life, in general, and teacher education more specifically" (p. 492).

In summary, the problem this research attempts to address is the marginalization of a specific group within the hip hop generation: black males. The voices of black males from the hip hop generation have been largely marginalized from scholarly conversations related to education reform and leadership, despite the fact that researchers argue that the schools must connect the sociocultural contexts of students' lives to the educational process. Hip hop culture is a sociocultural force that has informed the worldviews and actions of students for more than 30 years. Another problem this research addresses is that the intersections of schooling, hip hop culture and black masculinity have not been explored in a significant way in the broad range of research I have explored.

While the voices of black males are marginalized from the research literature around education reform and leadership, black males continue to woefully underperform in classrooms across America (Schott Report, 2010). That is, black male voices are marginalized from scholarly discussions and their achievement places them on the margins of academic excellence. In my hometown of St. Louis, Missouri, for example, 
approximately 2 of 5 black males graduate from local high schools (Schott Foundation for Public Education, 2010). The research below highlights the level of underperformance of black males. It evidences the presence of an achievement differential between black males and their non-black counterparts. It also strongly suggests a need for a new vision of educational leadership and reform.

According to data gathered from the 2009 National Assessment of Educational Progress test, a mere 1 out every 10 eighth grade black males reads at a level of proficiency (National Center for Education Statistics \& United States Office of Educational Research and Improvement, 2009). Further, according the Schott Report, (Schott Report for Public Education, 2010), black males are four times less likely than their white counterparts to take advanced placement classes. With regard to disciplinary consequences, the statistics are equally as disconcerting and disturbing. More than twice as many black males than white male students receive out of school suspensions, and three times as many black students are expelled (Schott Report for Public Education, 2010).

While there is an achievement differential between white male and black male students in P-12 education, there is also a college attendance and completion gap. In 2004, in colleges and universities around the country, 37 percent of black men were enrolled, compared with 42 percent of African American women and 44.5 percent of white males. The graduation rate of black men is lower than that of any group as well. Only 35 percent of black male enrollees graduated within six years from selective and highly selected colleges in 1996, compared with 59 percent of white males, 46 percent of 
Hispanic men, 41 percent of American Indian males and 45 percent of the black women who entered the same year (Alexander, 2004).

Undeniably, the data show the existence of an achievement gap; however, there are two distinct sets of narratives that seek to explain the underachievement. The dominant discourse would suggest that the gap exists because of a cultural pathology or because of an inherent, immutable intelligence, character or work ethic deficit (Hernstein \& Murray, 1994; Montagu, 1964). The opposing discourse would suggest a different reason for the achievement gap. The counter narrative would suggest that structures, policies and institutions create an educational context that privileges one race over another (Apple, 1982; Ladson-Billings, 1998; Yosso, 2005) and perpetuates an achievement differential. The counter narrative would suggest that educational outcomes that show marked differences across lines of difference must be examined and challenged from a critical lens (Solórzano \& Yosso, 2002).

Dr. Jawanza Kunjufu, noted researcher and educational consultant, advances a slightly nuanced and more accusatory voice to the counter narrative discourse. Kunjufu argues that black male underperformance is not accidental. Instead, he argues that, through the institution of education, there is a deliberate plan to limit the life chances of black boys. In his book, Countering the Conspiracy to Destroy Black Boys, Kunjufu (1982, p. 1) says,

The conspiracy to destroy black boys is very complex and interwoven. There are many contributors to the conspiracy, ranging from the very visible who are more obvious, to the less visible and silent partners who are more difficult to recognize. 
Kunjufu (1982) goes on further to assert that the conspiratory, deliberate actions to marginalize black males in school have been successful. He suggests that a race-gender brainwashing has occurred in our nation's schools, resulting in an indifferent, selfdeprecating archetype of black man. Kunjufu says, "Male seasoning thus becomes a dehumanization process of indoctrinating you against yourself...with no feelings and compassion for your children, women and brothers" (1982, p. 24).

\section{Hip Hop Culture's Counter Narrative}

Again, a master narrative normalizes structural incongruences and power asymmetries, while the counter narrative challenges structures, policies and mindsets that normalize inequality along lines of difference (Freire, 1970). With regard to hip hop culture, the master narrative is that hip hop culture is anti-intellectual, misogynistic, materialistic, violent and destructive creation that has led to the social and moral downfall of a generation (Dyson, 2006). On the other hand, the counter narrative suggests that hip hop culture is a global, revolutionary cultural force that has given disaffected youth a platform to express their multifaceted genius and voice. As a vehicle to express their worldviews, hip hop culture's counter narrative also suggests that hip hop culture provides a window into the world of a segment of black life. In the documentary, Voices of Rap: Looking for the Perfect Beat, Reverend Calvin Butts of Abyssinian Baptist Church in New York, described hip hop culture as, "The essence of who we are... a flag that is uncompromisingly black - put here by black people" (as cited by Bragg et al, n.d.).

In the same documentary Reverend Butts appears in, hip hop cultural icon Chuck D also provides a counter narrative around hip hop culture, suggesting that the culture has 
transformative and therapeutic aspects to it as well. Chuck D says hip hop culture has the potential to "fuel the mind, as well as the body and soul" (as cited by Bragg et al, n.d.).

One aspect of the counter narrative around hip hop culture suggests that its role in promoting nihilistic and self-oppressive mindsets and behaviors is part of a larger destroy the black community by destroying the black man conspiracy (Wise Intellect, 2009). In segments of the hip hop community, there is a belief that the most troubling aspects of hip hop culture's influence is a deliberate continuation of the movementhalting tactics initiated by COINTELPRO during the Civil Rights movement (Wise Intellect, 2009). Like Kunjufu, some in the hip hop community align to a conspiracy theory, suggesting that the marginalization of black men has been purposefully architected in such a way that is has become accepted as normal by both the oppressed and by the knowing and unknowing oppressor groups.

Artist Wise Intelligent, from the leftist group Poor Righteous Teachers, suggests that a revolutionary hip hop culture is a threat to the master narratives of black man as violent, materialistic, womanizing playa. In a speech shared at the Nation of Islam's Annual Saviour's Day Convention in 2009, Wise Intelligent suggests that the dominant narratives around hip hop are designed to foment a mindset that keeps the hip hop generation in a perpetual state of self-destruction (2009). He encourages his audience to examine the role racial prejudice might have in steering hip hop culture down a questionable path. Wise Intellect suggests that, just as the federal government created COINTELPRO, it also plays an active role in supporting a culture that promotes black self-oppression. 
"There are people in this society," Wise Intellect offers to the Saviors Day audience, “...who want to see us exactly where we are. You can not let that point elude you." (Wise Intellect, 2009) He also says that black males in the hip hop generation (specifically emcees) play a role in catalyzing movements and creating social justiceoriented worldviews for the culture. He argues that white capitalists who control the music outlets play an active role in perpetuating troubling master narratives around black males in hip hop culture. Wise Intellect alludes to whites' perpetuation of destructive narratives when he says,

Right now, we are feeding the prison industrial complex. Our kids are going to prison because they are promoting these records. They are promoting these records daily that send us to jail. Know what I mean? For us, it's cool to go to jail" (Intelligent, 2009).

In summary, both DuBois and Fanon speak of the implications of black males' identify confusion and the challenges that are the result of using white males as the gold standard. The same duality and conflict that the scholars defined generations ago is also evident in the hip hop generation, if I am representative of that group. Hip hop culture aligns with its troubling master narratives when, from a critical lens, its dominant messages support marginalization and deter personal and community agency.

The counter narrative around hip hop culture, however, is that it is an organic creation and representation of the fullness of urban culture. As hip hop icon Grandmaster Caz states in Something from Nothing: The Art of Rap (as cited in As cited in Toogood et al, 2012), "Hip hop culture didn't create anything. We recreated everything." While problematic at times, hip hop is reflective of both society's challenges and promises. Hip 
hop culture is reflective of the good, bad and ugly of the urban experience. The counter narrative also suggests that hip hop culture can be used to promote a mindset and actions that disrupt racial inequality. That is, hip hop can be used for emancipatory purposes and can bring the voices of the marginalized to the center. A problem this research will address - the marginalization of hip hop culture's black male voices in educational reform discourse - is a step towards expanding the discussion around ways to use hip hop culture and its cultural capital to support educational reform and leadership. Author, researcher and cultural critic, Michael Eric Dyson, warns against educators ignoring a significant sociocultural force in students' lives. He says,

Given its universal popularity and troubling effects, hip-hop is vital cultural language that we had all better learn. To ignore its genius, to romanticize its deficits, or to bash it with undiscerning generalities is to risk the opportunity to engage our children about perhaps the most important cultural force in their lives (Dyson, 2001, p. 138).

\section{Research Purpose}

In the hip hop world, being referred to as an $O G$ (original gangsta is the original term) is a demonstration of one of the highest forms of deference and respect one black male in the hip hop generation can bestow upon another. In short, an OG is a seasoned, highly-regarded black male who has earned credibility and respect among contemporary and younger members of the hip hop generation because of his accomplishments (very broadly defined). Using a critical lens informed heavily by hip hop culture, the overarching purpose of this narrative study is to expand the discussion around education reform and leadership by privileging the voices, schooling experiences and cultural 
capital of a marginalized group: the OGs of the hip hop generation. More specifically, the purpose of this study is threefold. First, this study aims to unpack the schooling experiences of a cohort of black men who self-identify as being part of the hip hop generation. Second, the research will explore the ways that the schooling experiences of the cohort align with both the master narratives and counter narratives around black men and schooling. Third, this research will explore the ways that hip hop culture has influence, inspired, informed and inhibited the research study participants.

Finally, in the findings section of this research, I will explore the implications that the worldviews, experiences and perspectives of the OGs might have for educational leadership and reform efforts. The findings might contribute to the research by informing educational reform and leadership, especially as it relates to the following themes:

1. Engaging black males in emancipatory, empowering schooling experiences

2. Unpacking the capital embedded in hip hop culture

3. Using hip hop culture to inform and expand educational leadership paradigms

4. Expanding the conversation around culturally responsive education

\section{Research Questions}

The following research questions will guide this study:

1. What are some of the schooling experiences of black men in the hip hop generation?

2. As a cultural force germane to the lives of many students of color, how has hip hop culture influenced the educated cadre of the OGs of the hip hop generation?

3. In what ways do black men in the hip hop generation represent a counter narrative to the dominant narrative of U.S. schooling experiences and outcomes for black men? 
4. In what ways do these same men contribute to the master narrative around black male in the hip hop generation - in either mindset or action?

\section{Theoretical Framework}

The overarching framework that guides this research is grounded solidly in Critical Race Theory (CRT), a lens that can be used to theorize, examine and challenge how race influences structures, policies and dominant narratives (Yosso, 2005). Five broad premises form the foundation of the CRT framework: 1) the import of racism and its intersectionality with other lines of difference; 2) a challenge to the dominant paradigms that facilitate the marginalization of people of color; 3) a social justice action orientation; 4) the import of culture-specific experience and knowledge and 5) a multidisciplinary approach to scholarship (Solorzano \& Yosso, 2002; Solórzano, 1997).

While CRT provides a general framework for analyzing, critiquing and dismantling racial inequality, authors Solórzano and Yosso (2002) suggest more education-specific addendums to the CRT lens. This research will be guided by the education-centric definition of CRT. Building on the five tenets of CRT, the educationspecific lens of the framework (a) contextualizes the lived experiences and (b) privileges the cultural capital of students of color. The researchers' nuanced CRT lens also challenges cultural deficit narratives about students by using counterstorytelling, oral traditions, media outlets, poetry and other cultural manifestations of people of color (Solorzano \& Yosso, 2002).

Finally, the education-centric CRT framework suggests that the achievement of people of color is not gauged primarily by standardized test scores. Instead, education is assessed by its transformative outcomes. That is, education should have a social justice 
oriented outcome, supporting the elimination of all forms of oppressions. In education should promote both agency and self-actualization opportunities for people of color (Matsuda, 1991).

Complementary to the CRT orientation, the counterstory challenges the dominant truths, knowledge and frameworks. Gloria Ladson Billings (1998) argues that, indeed, "there are well-developed systems of knowledge, or epistemologies that stand in contrast to the dominant Euro-American epistemology" (p. 258). With regard to its benefits, Hobbel and Chapman (2006) contend that the counterstory has four positive outcomes. The counterstory (a) builds solidarity within marginalized groups, (b) disputes the "unquestionable" wisdom of the dominant group, (c) motivates and strengthens the marginalized group and (d) creates a new reality and truth.

\section{Design for the Study}

For this study, a qualitative research design will be used to explore the experiences, worldviews and narratives embedded in the lives of those who embrace hip hop culture. More specifically, this study will use a narrative composite counterstorytelling methodology, as described by Yosso (2006). In this study, the composite counterstorytelling methodology privileges the composite narratives of black males and "aims to dislocate comfortable majoritarian myths and narratives" (Yosso, 2006, p. 212) about African-American members of the hip hop generation while chronicling their perspectives around issues related to the intersections of race, racegender, education and hip hop culture. By using the composite counterstorytelling method, the voices of study participants may challenge the master narratives - that "bundle of presuppositions, perceived wisdoms, and shared cultural understandings 
persons in the dominant race bring to the discussion of race', (Delgado \& Stefancic, 2012, p. 462).

Guided by a Critical Race Theory-informed lens, this study will follow the counterstorytelling composite methodology protocol by, first, deeply exploring research around hip hop culture. Second, I will use the focus group as my data collecting tool, to gather the stories of the participants. Third, I will use both my personal and professional experiences to contribute to the breadth and depth of the research. Finally, I will explore the themes emerging from the counterstories and create a narrative that captures those themes.

\section{Significance of the Study}

This research is significant in two primary ways. First, this qualitative research study unpacks the schooling experiences of a group of black males in the hip hop generation and explores the intersections between their schooling experiences and hip hop culture. This researcher was not able to access any similar research studies. Also, and

more specifically, this study explores the schooling experiences of a subgroup of hip hop OGs who have all obtained at least an undergraduate degree. The fact that, over the last three decades, three times as many black men were added to state and federal prison systems as were added to higher education rolls (Bureau of Justice Statistics, 2001), makes this group significant. This group represents a counterexample to the dismal statistics around black male graduation.

Second, Michael Dyson, in his book, Holler if You Hear Me: Searching for Tupac Shakur, proposes that there is an imminent danger in not exploring the connections between hip hop culture, students and, by extension, schools. He says, 
Given its universal popularity and troubling effects, hip-hop is vital cultural language that we had all better learn. To ignore its genius, to romanticize its deficits, or to bash it with undiscerning generalities is to risk the opportunity to engage our children about perhaps the most important cultural force in their lives (Dyson, 2001, p. 138).

In summary, while this study is significant because it explores the schooling experiences of a select group of black males, it is also significant because it does what Dyson recommends. This research examines both the narratives and counter narratives around hip hop culture, exploring both strengths and limitations of the sociocultural phenomenon that is hip hop - a key force in the lives of many students and in the lives of the research participants.

\section{Definition of Terms}

Critical. A critical orientation critiques and challenges power asymmetries through the intersections of race, gender, class and sexual orientation - and explores ways that these asymmetries influence both the marginalized and empowered groups. A critical view seeks to explore how areas of difference might impact, inform and influence privilege or marginalization.

Cultural Capital. (also called cultural wealth). Cultural capital refers to the portfolio of norms, values and customs that represent the assets of a specific group of people. The portfolio of assets that comprise a group's cultural capital help orient group members towards acceptable and unacceptable ways of talking, acting, dressing and even raising families. The degree to which a person has cultural capital dictates the level of access to the privileges of cultural group membership (Bourdieu \& Passeron, 1977). 
Dominant/Subordinate (also Oppressed/Oppressor) Groups. In Why Are All the

Black Kids Sitting Together in the Cafeteria?, Beverly Tatum provides an explanation of the concepts of dominant and subordinate groups. She states that, "Dominant groups, by definition, set the parameters within which the subordinate operates. The dominant group holds the power and authority in relative to subordinates and determines how that power and authority may be acceptably used" (1997, p. 41). In addition, Tatum suggests, "The dominant group is seen as the norm for humanity" (1997, p. 41). Tatum goes on to suggest that subordinate groups must defer to dominant groups, as they hold the key to their life trajectories (1997).

Empowering education (also, liberatory, emancipatory, transformative). An empowering education is one that is social justice-oriented and provides learners with the tools to empower themselves and their communities. Shor (1992) characterizes empowering education as:

... a critical-democratic pedagogy for self and social change. It is a studentcentered program for multicultural democracy in school and society. It approaches individual growth as an active, cooperative, and social process, because the self and society create each other. . The goals of this pedagogy are to relate personal growth to public life, to develop strong skills, academic knowledge, habits of inquiry, and critical curiosity about society, power, inequality, and change... The learning process is negotiated, requiring leadership by the teacher, and mutual teacher-student authority. In addition, the empowering class does not teach students to seek self-centered gain while ignoring public welfare. (pp. 15-16) 
Hip hop generation. Although the number of youth influenced by hip hop culture broadens as the culture continues to tattoo itself in suburban, urban, affluent, middle class and poor communities both nationally and internationally, for the purposes of this study, the definition of the hip hop generation will be defined more narrowly. For this study, a major criterion for membership in the hip hop generation is self-identification as a person of color from a low income or predominantly black community. Another aspect of membership in the hip hop generation is that one's formative (pre-teen and teen) years were dominated by aspects of hip hop culture, including worldviews, music, fashion, art, dance and/or scholarship.

OGs. In general, there are a few characteristics that describe an OG. First, very broadly speaking, an OG is a person embracing hip hop as the primary cultural force during his formative pre-teen and teen years. Also broadly speaking, and even more importantly, an OG is a highly-regarded black male who has credibility and respect among contemporary and younger members of the hip hop generation because of his accomplishments (very broadly defined) and his disposition. Generally speaking, the OG displays a physical and psychological stance Majors and Billson (1992) describe as a cool pose. The cool pose is a set of dispositions, physical posturing and ways of walking, talking and being that imply a certain toughness, aloofness and machismo (Majors and Billson, 1992).

An OG typically has strong relationships with black males that can be heavily involved in either the streets or the suites. That is, this OG cohort maintains relationships and is value-aligned with black men who may occupy and number of job roles, ranging from the criminal to the corporate. Also, very generally, an OG has considerable living 
experiences in urban and/or low income communities, or 'hoods. Last, an OG is typically a generation older than the current adolescents who embrace the most recent and popular iterations of hip hop music and culture. For the purposes of this study, OGs are at least 35 years of age. This is the group that has experienced by hip hop culture from the Golden Era of hip hop culture - Beat Street, Curtis Blow, Public Enemy, Run DMC, and Grandmaster Melle Mel - to the current era, dominated by the music of artists such as Kanye West, Lil Wayne, Jay Z, Rick Ross and even Yo Gotti.

Radical. In this study, radical is an overarching term used to describe value orientations, worldviews and actions that serve to challenge and dismantle both causes and effects of inequality, especially inequality based on difference. Specific to education, radical actions and mindsets have one overarching outcome: to aggressively and purposefully move towards educational equality through the development of critical consciousness and social justice-oriented activism. A radical educational change would privilege the capital of marginalized groups while leveraging a critical lens and current material reality to eliminate belief systems, practices and policies that contribute to educational differentials based on one's zip code or racial background.

Status Quo. Status quo refers to commonly-accepted worldviews, mindsets and actions that consciously or subconsciously normalize and maintain inequality based along lines of difference.

Transformative. The terms transformative and radical can be used interchangeably. Transformative implies a worldview and the concomitant reflection and action that lead to the elimination of inequality (Brown, 2006). 


\section{Organization of the Remainder of the Study}

Chapter 1 was comprised of an introduction and background to the problem; a statement of the problem; a discussion of both the purpose and significance of the study; an outline of research questions; a brief discussion of the guiding framework; an overview of the research design; and a discussion of salient terms. Chapter 2 will first provide a review of the literature around the history and development of hip hop culture. Then, prior to discussing the ways hip hop culture has impacted the landscape of P-20 education, this review will synthesize the essential elements of the conceptual framework, which is solidly grounded in tenets of Critical Race Theory (CRT). In Chapter 3, the researcher will present the methodology for the study. This will include a discussion of the research, examining the questions, methodology and design that undergird this study. Chapter 3 will also discuss the participants and sampling procedures. In addition, Chapter 3 will discuss the data collection and analysis procedures. Last, the chapter will review issues around trustworthiness. Chapter 4 will provide a review of the results of the research, and Chapter 5 will examine, interpret and discuss the results of the research, discussing theoretical and practical implications of the results. In addition, Chapter 5 will discuss limitations of the study and suggestions for future research. 


\section{CHAPTER 2}

\section{REVIEW OF RELATED LITERATURE}

\section{Introduction}

For at least 30 years, American youth, particularly urban youth of color, have both influenced and been influenced by hip hop culture (Petchauer, 2009; Basile, 2009, Kitwana, 2002). As poet M.K. Asante states in the documentary How Hip-Hop Changed the World (cited in Bridger, 2011), "We've all grown up with hip hop. It's been telling us what to do for about three decades." Over the course of the last three decades, hip hop culture has served as a means through which many youth embrace and name their realities, hopes, strengths and limitations (Kitwana, 2002). Even more specifically, in true Freireian form, hip hop culture represents a way that a generation of black male youth continues to read and write the world. As Cohen et al state, "Hip hop culture is a collective discourse which influences and is influenced by youth culture" (p. 23). For many youth, hip hop culture is the global positioning system that helps to orient them in the world. As Dimitriadis (2001) suggests, through hip hop culture, urban youth develop a sense of "self, place and history" (p. 78).

In the hip hop community, an $O G$ is a highly-regarded black male who has credibility and respect among contemporary and younger members of the hip hop generation due to his accomplishments (very broadly defined) and his disposition. An OG has obtained a portfolio of cultural competencies that have helped him negotiate and confront the narratives related to black males. This narrative study is designed to expand the discussion around education leadership and reform by 
privileging the voices, schooling experiences and cultural capital of a group of OGs.

This literature review has two broad goals. First, this review will explore the origins and sociohistorical evolution of hip hop culture. More specifically, the literature review will explore the origins of hip hop culture, its national and international outreach, its role as a socio-cultural movement, and its role in defining black male masculinity. Then, the review will explore research around hip hop's cultures infusion into education. While some of the implementation efforts align with more critical, emancipatory educational goals, other implementations prioritizing using hip hop culture as an apolitical referent and as a way to scaffold learning.

Last this literature review will outline the tenets of Critical Race Theory (CRT), the primary framework undergirding this study around black males, hip hop culture and education. CRT is a lens that can be used to theorize, examine and challenge how race influences structures, policies and dominant narratives (Yosso, 2005). While the overarching conceptual framework is oriented towards Critical Race Theory (CRT), the counterstory is a specific concept within the CRT framework that will be highlighted in the literature review as well.

\section{Hip Hop Culture: The Beginnings}

The phrase hip hop was first introduced to the world by deejays in New York City in the early 1970s (Kitwana, 2000; as cited in Toogood et al, 2012). As it became popularized and sanctioned by cultural legends such as Afrika Bambaataa, hip hop culture begins to take shape as a synergistic expression of urban life experiences vis a vis 
the culture's four main pillars - emceeing (rapping), deejaying, graffiti writing and breakdancing. Now, and for the last 30 years, hip hop has been an inextricable and dominant part of urban America's sociocultural DNA (Kitwana, 2002; Powell, 2000). Hip hop culture has indeed become a lifestyle brand (as cited in Toogood et al, 2012). While the origins of many elements of hip hop can be rooted squarely in the late 1970s and early 1980s, many iterations and aspects of the culture existed well before the 70s (as cited in Toogood et al, 2012). In fact, researcher Cheryl Keyes (1996) situates hip hop culture within both its African Diasporic and American contexts, providing a comprehensive survey of hip hop's development from its early years. In "At Its Crossroads: Rap Music and Its African Nexus," Keyes (1996) first situates hip hop music squarely along the continuum of music emanating from people of the African Diaspora. She does this by connecting the hip hop emcee (rapper) to his African Diasporic predecessors and contemporaries, positing that nommo - the transforming power of the spoken word - is an Africanism that is weaved in the multiple genres of black music in America - including the genre of rap music. Also, in "The Artistry of an Artifice of Black Communication," Ceola Baber (1987) contends that nommo, a force that occupies the being of Africans and their involuntary descendants, encourages resistance, selfaffirmation and resilience. Baber says, “...nommo generates the energy needed to deal with life's twists and turns; sustains our [blacks'] spirits in the face of insurmountable odds and transforms psychological suffering into external denouncements... and verbal recognitions of self-worth and personal attributes" (1987, p. 83).

Embodying the concept of nommo, like the black preacher, the charismatic politician, the radio disc jockey, and the blues singer, the hip hop emcee (rapper) 
continues the griot tradition in black America, evidencing the cultural wealth embedded in African American culture (Genovese, 1977; Rose, 1994). As discussed by Daniel Banks, in the book, Say Word! Voices from Hip Hop Theater: An Anthology (2011, p. 240),

The emcee (or MC) in Hip Hop culture functions in much the same way as the West African djeli (the Mande word for oral artist) or griot (a more commonly known term in the West). Like these oral artists, the emcee also tells of his community's issues, its values, its ancestors, its heroes and heroines, its triumphs, and its struggles.

One of the most influential predecessors of the hip hop emcee (rapper) and embodiment of nommo is the spoken word artist Gil Scott-Heron. Scott-Heron is said to be central to development of the social protest-oriented hip hop music. Heron's music began to gain critical acclaim in the early 1970s, just as few years before hip hop culture would enter into its infancy stages of development. Heron was a cultural critic, often exposing the outcomes of the pro-capitalist elite's seemingly-intentional marginalization of people of color. Heron offers class-centric (versus race-centric) critiques of the dominant society as well, highlighting challenges faced by people on society's economic fringes. Using spoken word supported by an instrumental track in the song "Blue Collar" (Heron, 2000, Track 2), the pre-hip hop "rapper" writes,

I been down in Pennsylvania Where I was working in the mine And I been down in Cincinnati They laid me off the assembly line Yeah, they got me looking everywhere But I ain't too proud of what I found And you can't name where I ain't been down 'Cause there ain't no place I ain't been down 
I was down in Kansas City

Where even the blues sell by the pound

And I been down in New York City, brother

And that ain't no place to be down

Yeah, I'm a-looking at the face of the children

You see, we're looking for a higher ground

And you can't name where we ain't been down

'Cause there ain't no place we ain't been down

We fell down somewhere

Between the cities and the towns

We went down, I know

Between the smiles and the frowns

And if they call me in the morning

I mean, I'd recognize the sound

'Cause you can't name where we ain't been down

There ain't no place we ain't been down

Standing in the shadows

It sho'nuff looks like rain

I see the steel-gray clouds above me

Yeah, well the anguish and the pain

Yeah, I been looking everywhere for peace

But I swear, there just ain't none around

But you can't name where I ain't been down

'Cause there ain't no place I ain't been down

Gil Scott Heron's work is important because his embodiment of nommo gave him a platform to give voice to the critical issues surrounding the people with whom he shared a Sam experience of oppression. Heron was a griot in the 1970s, and, as a cultural parent of the hip hop generation's children, he laid the groundwork for hip hop culture's critique of practices, policies and mindsets that contribute to the marginalization of people. In the tradition of King, X, Ali and Mandela, Heron spoke truth to power. When hip hop culture's icons garner the respect and platforms similar to their predecessors, they are a continuing a cultural legacy. Indeed, they are doing nothing new.

As articulated by hip hop artist Grandmaster Caz, in the documentary Something from Nothing: The Art of Rap (2012), hip hop culture is a fusion of things old with things 
new. That is, hip hop culture builds on the African Diasporic past to create a new cultural iteration. Caz, the hip hop godfather states, “Hip hop didn't create anything, but it recreated everything" (as cited in Toogood et al, 2012). Tricia Rose, in Black Noise: Rap Music and Black Culture in Contemporary America (1994), makes a similar assertion.

She states, "Hip-hop replicates and re-images the experience of urban life and symbolically appropriates urban space through sampling, attitude, dance, style and sound effects" (p. 22).

Some hip hop culture enthusiasts suggest that hip hop culture is created by a synthesis of five pillars instead of four (as cited in Bridger, 2011). The fifth element described simply as knowledge, wisdom and understanding - manifests itself as a worldview and set of knowledge and truths that guided the Zulu Nation, a cadre of disaffected black, Latino and poor white youth living in the Bronx in the 1970s. In a sense, the Zulu Nation played a role in both crafting and being crafted by hip hop culture. It is through the lens of the Zulu Nation philosophy, an African-centric, selfempowerment philosophy "designed to reverse the savage destruction that was happening in the black community," that Afrika Bambaataa elaborately detailed an organization structure and worldview that would mold the early development of hip hop culture (as cited in Bridger, 2011). In effect, Bambaataa had created an overarching narrative to create and catalyze a cultural movement supported by various forms of artistic expression.

Chuck D, of the group Public Enemy, refers to hip hop culture as, "CNN for black people" (Ridenour and Steiner, 2000). That is, like the popular news network, hip hop culture is a lens that reports a specific truth, informed by and reflecting a particular 
worldview. Hip hop culture, in its reporting a particular reality, can also create and shape reality. The following paragraphs outline material conditions and realities that informed the context in which hip hop culture icon Afrika Bambaataa and countless others from the Bronx helped to create.

Material conditions and the emergence of hip hop culture. An afterbirth of the Civil Rights/Black Power eras and strongly influenced by the increased marginalization of poor black and brown youth during the Reagan years, the cultural phenomenon of hip hop germinated in the late 70s and blossomed in early 80s in the Bronx Borough of New York City (Baszile, 2009; Low, 2010; Stanford, 2011). Hip hop scholar Bakara Kitwana (2002) suggests that economic trends such as the decline of manufacturing in urban centers and increased globalization contribute to the disproportionate marginalization of black men in the hip hop generation. While Kitwana speaks in more general terms about the social, economic, and cultural conditions that birthed hip hop culture, other researchers specifically locate the origination of hip hop culture within the context of the economic, educational and social transformation taking place in New York City, beginning in the 1950s, but coming to a head in the post-Civil Rights/Black Power era (Spencer, 1991; Wheeler, 1991; Baker, 1993; Keyes, 1996).

According to research conducted by both Cheryl Keyes (2001) and Eric Michael Dyson (2006), the intrusion of a major highway through a thriving Bronx neighborhood served as the first of a series of falling dominos, effectually leading to the dissolution of economic infrastructures and white working class neighborhoods. In the documentary How Hip Hop Changed the World, artist Idris Alba (as cited in Bridger, 2011) describes the intrusion as a "bulldozer plowing its way through the middle of the Bronx to create a 
fly over called the Cross Bronx Highway." One outcome of the new highway was a mass exodus of working class whites. As white flight took place in the Bronx in the late 1950s, poor communities of color flocked into the Bronx as occupants of low-income, low quality housing (Keyes, 2001). As Steven Hager (1984, p. 27) states in Hip-Hop: The Illustrated History of Break Dancing, Rap Music, and Graffiti, "the middle class Italian, German, Irish, and Jewish neighborhoods disappeared overnight. Impoverished black and Hispanic families, who dominated the southern end of the borough, drifted north. Along with the poor came their perennial problems: crime, drug addiction, [and] unemployment."

The material conditions of crime and high poverty among poor people of color in the Bronx that started in the 1950s had not changed by the 70s and early 80 s. An increase in poverty would eventually lead to an exponential increase in gang activity and violence in the 70s. One researcher estimates that, in New York City in 1973, there were at least 19,000 gang members (George, 1992). Also, while gang membership became increasingly problematic in New York's poor communities, there was a noticeable decrease in the funding of arts programs in schools - at least that is how it felt to some members of the hip hop generation. As highly acclaimed East Coast emcee, Lord Jamal states,

We created something from nothing with hip hop. That's what the whole spirit of hip hop is. See, that's about the time they were taking instruments out of the schools. You know, black people are some musical motherfuckers (as cited in Toogood et al, 2012). 
Similarly, at the National Education Association Conference in 1994, writer and keynote speaker Thulani Davis suggests that instruments in the classroom evaporated and elements of hip hop were created as a result of this void in music options. Davis argues that the days of instruments in the classroom had been replaced by "street arts like rap... those little instruments we once learned to play in the classroom, those [days] are gone" (as cited in Keyes, 1996).

While white flight, urban neglect, poverty, increased gang membership and decreased funding of the arts and humanities were material realities that helped to birth hip hop culture, it was a small cadre of Bronx youth who transformed oppressive material conditions to create a cultural force that "would change the world as we knew it" (as cited in Bridger, 2011). While there are many urban youth who added color to the development of hip hop culture, Afrika Bambaataa is generally considered hip hop's culture's founding father. Hip hop emcee, actor, and entrepreneur Nas holds Bambaataa in high regard, calling him, "the light" (as cited in Toogood et al, 2012).

As gangs flourished in the 70s and the economy negatively impacted black and Latino Bronx residents, Afrika Bambaataa was creating an organizational base for the region's gangs: the Zulu Nation. From the Zulu Nation's beginnings, Bambaataa had social justice-oriented aspirations. He states that he envisioned hip hop culture as a way to eliminate "black on black crime, black on Latino crime, Latino on Latino crime" (as cited in Toogood et al, 2012). As he also states, "We took the energies of the negative tried to change it around and bring positivity to the organization by giving you hip hop" (as cited in Toogood et al, 2012). 
A counter to the worldviews that currently dominate mainstream hip hop culture, Bambaataa roots hip hop culture's founding worldview in Abrahamic law, pro-justice and environmentalist sentiments. The Zulu Nation's tenets are found in Table 3 below:

\section{Table 3}

Platform of the Universal Zulu Nation ("Beliefs of the Universal Zulu Nation," 2013)

1. Belief in the Abrahamic God

2. Belief in the validity of the Bible (Old and $\underline{\text { New }), ~ Q u r ' a n ~ a n d ~ i n ~ t h e ~ s c r i p t u r e s ~ o f ~}$ all the Prophets of God.

3. Belief that the scriptures have been tampered with

4. Belief that history textbooks and other educational materials have been negatively influenced by white-supremacist doctrines

5. We believe in truth whatever it is. If the truth or idea you bring us is backed by facts, then we as Amazulu bear witness to this truth. Truth is truth." Belief that religion should not make adherents into a slave or zombie but should instead make them a fighter for freedom, justice, and equality for all human beings.

6. Belief that racism is attempting to destroy civilization.

7. Belief that humanity must stop destroying the environment.

8. We believe in the mental resurrection of the dead. There are many of the Human race who are blind, deaf, and dumb to the knowledge of self and others, and we feel the ones who know should teach."

9. Belief that mathematics is the foundation of all reality.

10. We believe in the seen and what is to be known of the unseen. We believe in the power of the mind, and that knowledge is as infinite as God himself."

11. Belief in equal justice for all.

12. Belief in peace unless provoked.

13. We believe in power, education in truth, freedom, justice, equality, work for the people, and the up-liftment of the people.

14. The Universal Zulu Nation stands for knowledge, wisdom, understanding, freedom, justice, equality, peace, unity, love, respect, work, fun, overcoming the negative, economics, mathematics, science, life, truth facts, faith, and the oneness of God.

While Afrika Bambaataa and his Zulu Nation are generally credited with creating the manifesto and philosophy undergirding hip hop culture, members of the Zulu Nation are also the founders of two of hip hop culture's artist pillars - breakdancing and graffiti writing. Breakdancing -- a combination of ticking moves, spinning, and urban acrobatics 
- began as a way for rival groups to remain competitive while avoiding violent outcomes. Breakdancing battles between rival groups, the Black Spades and the Savage Nomads (as cited in Toogood et al, 2012) are considered legendary in hip hop folklore. Breakdancing culture gained popular visibility through two hip hop movie classics, Breakin' and Beat Street. Hitting movie theaters in 1984, both movies featured lead antagonists who used breakdancing as a way to positively impact community.

Graffiti - large, artistic, individualized lettering patterns and symbols typically painted onto subways, trains, bridges and building -- also created by members of the Zulu Nation, is visible throughout urban and suburban communities both nationally and internationally (Bridger, 2011). Enthusiasts of hip hop culture suggest that graffiti writing (or tagging) allows those on the margins of society to humanize themselves and to assert their self-worth. As legendary hip hop deejay suggests, tagging is a way to "make yourself known all over New York. People all over the world know you" (as cited in Bridger, 2011). Zulu Nation graffiti writers are considered the originators of the art of graffiti writing in New York (Bridger, 2011).

Deejaying and emceeing (rapping), the remaining two elements of hip hop culture, were created by the same social realities that created breakdancing and graffitiwriting. Very specifically, though, gang violence that began to spread into New York discos played a significant role in creating both deejaying and emceeing (George, 1988). As the concerns about violent crimes in discos increased, youth in the South Bronx community decided to provide other outlets for partying. Basketball courts, tennis courts and parks became the party venues in the Bronx. For community residents, these places were peace zones, unlike the war zones discos had become. As one music disc jockey 
states, "it got too dangerous for people to go to discos" (Keyes, 1986). Eventually, Kool DJ Herc, Grandmaster Flash, Melle Mel, and The Furious Five would lay the groundwork for many other deejays and emcees to come after them (Keyes, 1986).

A man of Jamaican descent whose family first arrived to New York City in the early 50s, DJ Herc revolutionized the party scene in the Bronx and is known as the godfather of deejaying. Borrowing from reggae dub artists like $\mathrm{U}$ Roy, Herc is credited with creating the art of mixing, a means of assembling seemingly disparate clips of music into a cohesive, structured musical arrangement. Herc would precede other hip hop innovators, Afrika Bambaataa and Grandmaster Flash, in using multiple pieces of music to creating a continuous soundtrack that would keep partygoers on the dance floor (George, 1998; Kitwana, 2002). Not only would DJ Herc keep the party going with his innovative mixing, but he was known to have the largest pair of speakers in the Bronx. He would often be seen driving in his convertible with the pair of speakers fully occupying the back seat (Bridger, 2011).

As deejaying began to grow in popularity in New York, several of the original deejays decided to partner with a wordsmith who would lay spoken words over mixed tracks, very similar to what Gil Scott Heron had done a decade or so prior. As a result, the rapper (or emcee) was born. In the early days of hip hop, Afrika Bambaataa, Kool DJ Herc and Grandmaster Flash all enlisted emcees to complement their deejaying. Also, in the beginnings of hip hop's emergence as a cultural force, Melle Mel was one emcee who helped to bring attention to the material conditions in urban America's poor communities. Prior to his presence, 
the hip hop emcee emphasized dancing, fun, and machismo (Bragg et al, n.d.;

Bridger, 2011). His group's signature piece, "The Message," is an exemplar of hip hop culture being a vehicle for social criticism. Providing a window into his world and operationalizing nommo, Melle (Flash, G. \& The Furious Five, 2002, Track

2) describes life in his Bronx community:

Broken glass everywhere

People pissin on the street

You know they just don't care

Can't take the smell, can't take the noise

Got no money to move out

I guess I got no choice

Rats in the front room

Roaches in the back

Junkies in the alley

With the baseball bat

I tried to get away, but I couldn't get far

Cuz the man with the tow truck repossessed my car

Don't push me cuz I'm close to the edge

I'm trying not to lose my head

It's like a jungle sometimes, it makes me wonder

How I keep from going under

\section{Hip Hop Culture's National and International Outreach}

While the beginnings of hip hop culture can be traced to poor youth of color in the South Bronx section of New York City, it has indeed crossed over. That is, hip hop culture has weaved itself across lines of racial difference in America, and is not just a part of the poor, urban American landscape (Morell \& Duncan-Andrade, 2002; Farley, 1999; Kitwana, 2002). As Abe (2009) indicates, "From fashion to vocabulary to marketing and beyond, hip-hop has permeated the overall texture of American society and has come to define for the population at large what's new and what's next"(p. 264). To further drive the point, according 
to hip hop culture expert Bakari Kitwana (2005) and hip hop scholars Morell and Duncan-Adrade (2002), white youngsters purchase hip hop music at a significantly higher rate than their black peers.

Not only has hip hop culture shaped the landscape of American culture, but it has also made a name for itself internationally (Iwamoto et al, 2007; Basu \& Lemelle, 2006). Major mainstream British hip hop artists, for example, talk about the role of the Fresh Prince in defining culture. As one popular hip hop icon says (as cited in Bridger, 2011), "Back then, you never really saw black people on TV and then you see this show, and then you think, okay this is actually possible." Even the late Prince Charles of England did a drive by of hip hop culture, as he put on a set of deejay headphones and mixed on set of turntables - for a set of cameras. As he finishing his mixing experience, he exclaimed, "Dig that crazy rhythm" (as cited in Bridger, 2011).

In addition, hip hop culture icons have amassed considerable wealth, tapping into both national and international markets. Hip hop artists such as Jay Z, Sean "Diddy" Combs, and 50 Cent sold out stadiums in Japan, England and South America and have sold millions of albums outside of the United States. Also, according to Forbes' list of hip hop's wealthiest artists, each of the aforementioned artists has a fortune of least $\$ 270$ million, with Combs being the forerunner with a net worth of $\$ 550$ million (Greenburg, 2012).

\section{Hip Hop as A Movement Committed to Social Critique and Change}

In September of 2011, Time describes hip hop culture as "the most important youth culture on the planet" (Powell, 2011). In some ways, hip hop culture represents a social movement, as defined by social theorist Albert Melucci. According to Melucci's 
(1996) social movement theory, movements cause status quo-upsetting actions by pulling the scab off of the power asymmetries that naturalize the status quo. Movements highlight causes, symptoms and consequences of inequality. Melucci (1996), says movements "... are the prophets of the present. They force power out into the open and give it a shape and a face. They speak a language that seems to be entirely their own, but they say something that transcends their popularity and speaks to us all” (p.1).

In hip hop culture, the marginalized articulate a collective challenge to existing power structures. The Hip Hop Action Network website (2009) suggests that, "Hip hop is an enormously influential agent for social change which must be responsibly and proactively utilized to fight the war on poverty and injustice." While there are many exemplars of hip hop culture's penchant towards creating a movement that exposes power asymmetries and voices resistance, none is more illustrative than the songs " $\mathrm{F} * * \mathrm{k}$ the Police" and "Made You Die."

In 1986, four men emerged from the low income, high crime community of South Central Los Angeles and created $\mathrm{Ni}^{* * a}$ az with Attitudes (NWA), a hip hop group whose music themes ranged from social criticism to misogyny and black on black crime. In the song "F**k the Police," though, the group NWA offers a scathing criticism of the power dynamics between authoritative police officers and disempowered persons of color. In response to what they perceive to be racially unjust practices of the LAPD, rappers Ice Cube, Easy Z, Dr. Dre, and MC Ren (1988) say:

$\mathrm{F}^{* *} \mathrm{k}$ tha police

Comin straight from the underground Young ni**a got it bad cuz I'm brown And not the other color so police think They have the authority 

To kill a minority
...Fu**in with me cuz I'm a teenager
With a little bit of gold and a pager
Searchin my car, lookin for the product
Thinkin every ni**a is sellin narcotics (Track 3).

In response to the Trayvon Martin killing, where a young black male was killed by a white, self-appointed neighborhood watchdog who said he shot Trayvon in selfdefense, hip hop artists Yasiin Bey, Dead Prez and Mikeflo (2012) provide an analysis and critique of what they consider to be an unjustifiable homicide and example of the lack of regard for black life. Emcee Yasiin Bey says,

I'm tired of the marchin', the rallyin', the protestin'

We whoopin' and hollerin', but still we getting' no justice...

Forget all the media hype

We plot plan and strategize. We ready to fight

The government ain't gon' stop it as long as they make a profit

Off of our criminalization, our people gon' be a target (Bey et al, 2012)

Not only do hip hop artists and groups offer scathing criticisms of power asymmetries in their music, as demonstrated by the song lyrics of NWA and Trayvon Martin supporters, but many of the hip hop generation engage in collective political action in the fight for economic, social and political equality. The Hip Hop Summit Action Network (HSAN) is an example of hip hop culture being used as a means to engage the generation in the movement to balance the scales of social justice through political action. Founded in 2001 and supported by notables such as Russell Simmons, Sean "Diddy" Combs and Young Jeezy, HSAN has sponsored political empowerment conferences in more than 40 cities across the country (Allwood, 2012). HSAN has also engaged Congressional Black Caucus leaders such as Congresswoman Maxine Waters 
(D-CA) and Congressman Earl Hilliard (D-MI) in efforts to leverage the hip hop generation's previously-untapped political empowerment potential (Allwood, 2012).

Providing a paradigm for engaging the hip hop generation in community activism, the Network's expressed mission is to "harness the cultural relevance of hip-hop music to serve as a catalyst for education advocacy and other societal concerns fundamental to the empowerment of youth" ("Mission statement," 2012). Similar to black nationalist organizations such as the Nation of Islam and the Black Panther Party, HHAN articulates a platform with a set of radical demands ("Want we want," 2012).

Table 4

Hip Hop Action Network Platform

1. We want freedom and the social, political and economic development and empowerment of our families and communities; and for all women, men and children throughout the world.

2. We want equal justice for all without discrimination based on race, color, ethnicity, nationality, gender, sexual orientation, age, creed or class.

3. We want the total elimination of poverty.

4. We want the highest quality public education equally for all.

5. We want the total elimination of racism and racial profiling, violence, hatred and bigotry.

6. We want universal access and delivery of the highest quality health care for all.

7. We want the total elimination of police brutality and the unjust incarceration of people of color and all others.

8. We want the end and repeal of all repressive legislations, laws, regulations and ordinances such as "three strikes" laws; federal and state mandatory minimum sentencing; trying and sentencing juveniles as adults; sentencing disparities between crack and powdered cocaine use; capital punishment; the Media Marketing Accountability Act; and hip-hop censorship fines by the FCC.

9. We want reparations to help repair the lingering vestiges; damages and suffering of 
African Americans as a result of the brutal enslavement of generations of Africans in America.

10. We want the progressive transformation of American society into a $\mathrm{Nu}$ America as a result of organizing and mobilizing the energy, activism and resources of the hip-hop community at the grassroots level throughout the United States.

11. We want greater unity, mutual dialogue, program development and a prioritizing of national issues for collective action within the hip-hop community through summits, conferences, workshops, issue task force and joint projects.

12. We want advocacy of public policies that are in the interests of hip-hop before Congress, state legislatures, municipal governments, the media and the entertainment industry.

13. We want the recertification and restoration of voting rights for the 10 million persons who have lost their right to vote as a result of a felony conviction. Although these persons have served time in prison, their voting rights have not been restored in 40 states in the U.S.

14. We want to tremendously increase public awareness and education on the pandemic of HIV/AIDS.

15. We want a clean environment and an end to communities in which poor and minorities reside being deliberately targeted for toxic waste dumps, facilities and other environmental hazards.

\section{Troubling Narratives of Black Masculinity in Hip Hop Culture.}

Hip hop culture, while it has strong capital embedded within it, also has some limitations, some critics offer. One of the critiques of hip hop culture (particularly hip hop/rap music) is that it normalizes misogyny. With regard to rap music's dominant messages about women, Tricia Rose suggests,

Raps about style and prestige sometimes involve the possession of women as evidence of male power. Predictably, these raps define women as commodities, objects, and ornaments. Others are defensive and aggressive raps that describe women solely as objects (2004, p. 295). 
While there are myriad examples of rap lyrics that support Rose's argument, the lyrics in Jay-Z's song Big Pimpin' serve as an appropriate example, especially because of its popularity. The song was listed as one of Rolling Stone's 2010 list of 500 Greatest Songs of All Time. In the song, hip hop culture icon Jay-Z describes the times when he needs female companionship. He says,

I'm a pimp in every sense of the word bit*h You betta trust and believe him In the cut is where I leave 'em

Till in need a nut

Till I need to beat the guts

Then it's beep beep then I'm pickin' em up

Let 'em play with the $\mathrm{d}^{* * *} \mathrm{k}$ in the truck (2010, Track 14)

While Jay-Z's lyrics promote misogyny, he is not the only rapper to do so. While similar sentiments characterize some subgenres of hip hop music, what is commercially known as gangsta rap is arguably most misogynistic. Hip hop artists/groups such as NWA, Snoop and Young Jeezy, while multiplatinum artists, have songs that promote the marginalization of women.

Along with critiquing the misogynistic messages in more current popular hip hop music, some suggest that hip hop culture limits the definition of black masculinity hood by making the playa-tough guy archetype normative. As Oware (2010, p. 22) states,

Many rappers construct a black male subjectivity that incorporates the notion that masculinity means extreme toughness, invulnerability, violence and domination.

Moreover, the cornerstones of rap music - hypermasculinity, misogyny, and homophobia - pervade the genre.

Researchers Majors and Billson (1992) coined the phrase cool pose to define the hypermasculine archetype Oware describes above. Hip hop culture privileges this 
definition, thereby marginalizing other archetypes of masculinity, especially

homosexuality. McCune, in his research article, "'Out in the Club: The Down Low, Hip Hop and the Architexture of Black Masculinity" (2008, p. 301) describes the internal conflict and identity confusion around being a gay man in hip hop culture. He speaks of his alienation:

My black queer world consisted of a ravaged imagination with no playground to explore and/or to experiment with. This understanding of black gay men as invisible or 'quiet' continued into my collegiate experiences as the predominant gay presence.

To summarize the literature around hip hop culture, I first explored hip hop culture's beginnings in The Bronx, New York. I next discussed hip hop culture's national and global impact. A discussion of hip hop's alignment with an activist, social justice orientation was offered next. Last, I explored troubling narratives embedded in mainstream hip hop culture that promote misogyny and homophobia. Next, I will explore how hip hop culture, now a global economic, social and political force, has been connected to students' schooling experiences in P-12, higher education and in therapeutic environments.

\section{The Limited Research on Hip Hop Culture in Schools}

Not only is hip hop culture a part of the efforts to promote political activism and foment a social justice movement led by the hip hop generation, but hip hop culture is also being used to impact the schooling experiences of many of today's youth. As Duncan-Andrade and Morrell (2002) suggest, hip hop culture's impact on students is evidenced by the fact that, upon a school visit to any urban school, one might see the 
evidence of the hip-hop culture's influence embodied in the "expressionistic style and innovation of young people today" (p. 90). Hip hop culture - a cacophonous discourse and multifaceted worldview that reflects, resists and reproduces the realities of urban life - is evident in both $\mathrm{P}-12$ education and in the walls of the academy. While limited, there I research around ways that hip hop culture has been used to drive educational practice. Specific literature around the intersections of hip hop culture, race, race-gender, and their connections to educational leadership is largely absent, however. This is one of the voids tis research attempts to address.

This literature review will outline the research around Hip Hop Based Education, or HHBE. Broadly defined, Hip Hop Based Education (HHBE) is the educational practice of integrating hip hop music, text and culture into the academy and into P-12 education. HHBE is part of a larger effort in education to consider the sociocultural factors that impact a student's schooling experiences (Petchauer, 2009; Duncan-Andrade \& Morell, 2000; Horsford et al, 2011). These efforts are typically aggregated into two broad pedagogical orientations: culturally responsive/relevant pedagogy and antiracist/critical pedagogy (Horsford et al, 2011). Before fully exploring the research around HHBE that falls into either of the broad categories, I will first provide more robust definitions of each.

Culturally Relevant/Responsive Pedagogy. Introduced first by Gloria LadsonBillings (1994), culturally relevant pedagogy (also culturally relevant instruction or culturally relevant teaching) is designed to empower "students intellectually, socially, and politically by using cultural referents to impart knowledge, skills, and attitudes" (p. 18). This culturally relevant paradigm is one that respects, values and affirms students' 
personal and historical backgrounds and experiences. In her book The Dreamkeepers, Ladson-Billings (1984), describes the archetypical transformative teacher of black students in two distinct ways. First, she summarizes a set of core values that undergird the transformative educator. Then, she outlines a set of actions and competencies.

First the core values are as follow:

1. They have high self-efficacy and high regard for others, especially those from historically marginalized backgrounds.

2. They see themselves as part of the community. They see teaching as a way of serving the community, and they encourage their students to give back to the community.

3. They see teaching as an art and themselves as artists.

4. The help students make connections among their community, national, and global identities.

5. They truly believe that all students can be successful.

They see teaching as an unearthing of the knowledge and genius in each child (Ladson-Billings, 1984).

Almost twenty years later, Ladson-Billings argues for a more radical set of interrelated actions designed to operationalize the core values undergirding culturally responsive teaching. In Crossing Over to Canan: The Journey of New Teachers in Diverse Classroom (2001), Ladson-Billings proposes that culturally responsive teachers must help students develop a sense of sociopolitical consciousness, or what Freire calls conscientizacao. In addition, she argues that the educators must not prioritize academic achievement with instruction and assessments that consider multiple intelligences, ways 
of thinking and cultural norms. Finally Ladson-Billings (2001) contends that teacher must be deep level of cultural consciousness. More importantly, the educator's role is ensure that students that students have a deep cultural understanding and competence.

Researcher Geneva Gay (2002, p. 106) adds to culturally responsive/relevant pedagogy, stating that, "The knowledge that teachers need to have about cultural diversity goes beyond mere awareness of, respect for, and general recognition of the fact that ethnic groups have different values or express similar values in various ways. In fact, Gay (2002) lays out five important keys to creating a culturally responsive classroom environment, some of them similar to previous propositions:

1. Teachers must develop a cultural knowledge base. Teachers should know:

a. Which ethnic groups prioritize communalism versus individualism. Teachers should consider cultural preferences when considering engagement techniques and when making assignments.

b. Culturally-specific norms for student-adult interactions

c. The role cultural socialization plays in defining gender roles

2. Teachers must develop culturally relevant curricula. Curricula cannot avoid issues like, "racism, historical atrocities, powerlessness, and hegemony" (p. 106). Curriculum must not focus on the accomplishments of a small number of popular figures in ethnic groups while ignoring other, less well-known figures. In addition, attention must be paid to organization, and not just individuals. Also, culturally relevant curricula must include a variety of knowledge and perspectives - not just those from the most popular diverse groups. 
3. The classroom must focus on culturally-specific ways of showing love, respect and caring.

4. Various communication styles should be respected and validated.

Communication styles are a part of a student's cultural capital. Teachers must be able to encode and decode communication styles in order to teach most effectively.

5. Cultural congruity in classroom instruction should be a norm. Research has shown that learning styles do have core structures, and specific patterns that align with ethnic groups (Shade, 1989). The structure of ethnic learning styles includes at least eight key components (which are configured differently for various groups)

a. preferred content; ways of working through learning tasks

b. techniques for organizing and conveying ideas and thoughts

c. physical and social settings for task performance

d. structural arrangements of work, study, and performance space

e. perceptual stimulation for receiving, processing, and demonstrating comprehension and competence

f. motivations, incentives, and rewards for learning

g. interpersonal interactional styles

Although Ladson Billings (2005) explicitly contends that that one of the priorities of culturally relevant pedagogy is, "the development of sociopolitical or critical consciousness" (p. 106), some researchers contend that it is not liberatory. Horsford et al (2011) for example, suggest that the orientation is criticized because it fails to explicitly 
challenge issues of institutional racism, privilege, power and oppression.

Critical/antiracist pedagogies, it is suggested, is more aggressive in its approach to providing emancipatory educational opportunities for students (Lawrence \& Tatum, 1997).

Critical/Antiracist Pedagogy. Explicitly challenging the status quo is a hallmark of the critical/antiracist pedagogical orientation . An orientation informed by a number of radical scholars, critical/antiracist pedagogy takes the position that educators must first, examine assumptions and bias as they consider ways that race, power, privilege and oppression play a role in educators' and students' lives (Ladson-Billings and Tate, 1995; Yosso, 1995). In alignment with this orientation, educators must situate schooling in sociocultural contexts, and they must have engagement with students around race and school (Gay, 2000; Horsford et al, 2011; Ladson-Billings, 1998).

While examining assumptions and bias is a crucial step, scholars argue that examination and critique must lead to antiracist action. Antiracism must be used for dismantling racist structures and for building racial justice and equality (Lee, 1985). Researcher Beverly Daniel-Tatum compares antiracist actions in school to walking in reverse on a people mover, typically in an airport. That is, antiracist educators' actions must counter institutionalized racism and other forms of oppression. Tatum, along with Sandra Davis (1997), outline antiracist best practices in three broad areas of the schooling experiences: 1) School/community and interpersonal, 2) curriculum and 3) institutional change. Table 5 provides a summary of the practices. 


\begin{tabular}{|c|c|c|}
\hline \multicolumn{3}{|c|}{$\begin{array}{l}\text { Table } 5 \\
\text { Antiracist Actions in Three Areas of Schooling }\end{array}$} \\
\hline $\begin{array}{l}\text { School/Community and } \\
\text { Interpersonal Relationships }\end{array}$ & Curriculum & Institutional Change \\
\hline $\begin{array}{l}\text { 1. Communicating high } \\
\text { expectations to students } \\
\text { of color }\end{array}$ & 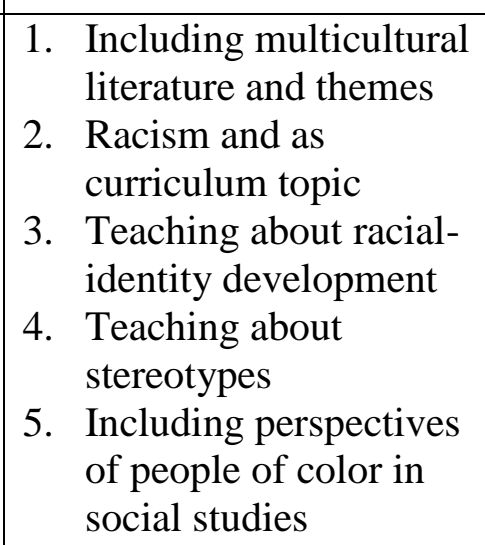 & $\begin{array}{l}\text { 1. Question assessments } \\
\text { for special education } \\
\text { 2. Challenging racist } \\
\text { behaviors among } \\
\text { current or prospective } \\
\text { staff } \\
\text { 3. Changing grouping or } \\
\text { testing practices } \\
\text { 4. Providing support } \\
\text { programs for students of } \\
\text { color }\end{array}$ \\
\hline
\end{tabular}

In summary, both culturally responsive/relevant and antiracist/critical orientations are attempts to locate education within a sociocultural context and provide students with access to expanded educational opportunities. While the culturally responsive/relevant paradigm encourages a social justice-oriented conscientizacao, the critical/antiracist paradigm is generally accepted to be more radical, as it promotes the changing of systems and structures, not just a critique,

Next, this literature review will examine the research that aligns with the more radical/antiracist iteration of HHBE. In terms of Sam themes, all of studies prioritized creating learning environs that foster student and teacher collaboration toward actions that challenge the status quo. In these research studies, hip hop has been used in a more radical, Freireian problem-posing manner, seeking to empower both student and teacher with a critical consciousness of concrete realities related to racial oppressions and other forms of oppression. This liberatory educational orientation is also culturally responsive, 
in the sense that it is asset based, centralizing and valuing the worldviews and experiences of people of color (Yosso, 2005). This educational orientation operates under the premise that a critical consciousness must inspire agency among people of color in a way that leads to both personal and societal transformation (Freire, 1970; Watts et al, 2002).

Second, this literature review will explore the research studies that use hip hop culture as a scaffold to lead to improved educational outcomes. In the studies, hip hop culture is a way to connect marginalized students to dominant educational practices, pedagogies, ways of knowing and the traditional canons. It means, for example, that students can glean as much from Public Enemy and Tupac Shakur as they can from George Orwell. The ultimate goal is for students of color to gain skills and competencies by using hip hop culture. While the iterations are culturally relevant, they are not explicitly oriented toward emancipatory outcomes for students.

It should be noted that hip hop has not just been infused into traditional K-12 classrooms and collegiate classrooms. Hip hop culture has also been used in afterschool programs and extracurricular programs. Also, scholars have begun to recognize that hip hop culture can have a therapeutic value also. In other words, hip hop can be used as a form of intervention for youth of color. This literature review will also highlight some of the research around the ways hip hop has been used as a therapeutic intervention as well.

\section{Critical/Antiracist Pedagogy: The Research}

The research literature outlines a particular manifestation of Hip Hop Based Education, Critical Hip Hop Pedagogy (CHHP). CHHP argues for a more nuanced notion of community cultural production - one that positions communities of color and their 
experiences as central subjects to knowledge production. Through CHHP, members of the hip hop generation fuse the cultural wealth (or challenges) in hip hop culture with a drive towards social justice-oriented action. In the research, studies driven by the CHHP orientation generally employ the problem posing paradigm as outlined by Paulo Freire in Pedagogy of the Oppressed (2000). This problem-posing paradigm, which challenges the dominant student-teacher hierarchical relationship paradigm, has the following steps:

1. Begin with identifying and defining a problem, challenge or issue of concern in the school or in the larger community.

2. From a CRT lens, analyze the concrete social, political, economic or cultural conditions that contribute to the problem. Using a critical lens necessarily means one will examine structural asymmetries in systems and institutions, including schools.

3. Examine range of viewpoints regarding why the problem exists. Be very clear about examining problem explanations from CRT perspectives.

4. Pose solutions and act on solutions in a way that leads towards self and community agency. Pose solutions that challenge the marginalization of outgroups.

5. Analyze the impact of posed solutions as it relates to their ability to disrupt the status quo (Akom, 2009).

Critical Hip Hop Pedagogy is a means to engage students around hip hop culture in a way that examines social conditions and incongruences across lines of difference. The ultimate goal of CHHP is to foster a radical change in the educational landscape, primarily focusing on students of color. By employing culturally congruent pedagogical 
and andragogical strategies, CHHP infuses hip hop into schooling in a way the poses a challenge to current hegemonic educational practices. It particularly examines hip hop culture as it intersects with race, class, gender, and sexual orientation. In addition, CHHP is still evolving in terms of analyzing and theorizing to what extent hip hop can be used as a tool for social justice in teacher education and beyond (Akom, 2009) and is aligned with Shor's definition of empowering education.

The literature points to a number of studies around implementing CHHP across the P -12 curriculum and in the academy. In order for educators to implement CHHPoriented strategies, they must first embrace a transformative, emancipatory orientation towards schooling. They must believe that schools should be used to challenge inequality. Researcher Izarray's work is informative in this area, as he conducted a study to gain a comprehensive understanding of the characteristics of transformative urban school teachers.

Relationship between teacher representin' and antiracist actions. Researcher Izarray (2009) uses a term embraced by the hip hop generation, representin', to describe this set of best practices that antiracist/critical educators use when integrating hip hop culture into educational arenas. In the research article, Representin': Drawing From Hip Hop Urban Youth Culture to Inform Teacher Education, Irizarry (2009) situations the action of representin' into a radical teacher education context. In the hip hop culture, representin' is an outward expression of pride and accomplishment. Representin' is a positive representation of the hip hop generation as a cultural group. It is an expression of a particular element of cultural capital in hip hop. When a person from the hip hop 
culture achieves a goal, especially using actions or practice commonly associated with hip hop culture, he is representin'.

In education, teacher representin' leads to critically conscious students who are committed to disrupting current narratives around black student underachievement. Izarazzy's research suggests (2009) that, in teaching, representin' is aligned with the more radical tenets of culturally responsive teaching, in the sense that it challenges both student and teacher to fight against the status quo. In addition, representin' causes teachers to be aware of themselves as having subjectivity and biases that play into their actions as beings, specifically, as educators. A teacher that represents speaks truth to power, incorporates students' culture and contemporary and historical experiences into curriculum, provides students with in an opportunity to view education through the prisms of race, class, and gender (Irizarry, 2009). Irizarry suggests that a teacher engaging students in the hip hop generation must represent.

CHHP in action. Examples of the implementation of research informed by CHHP are present in both $\mathrm{P}-12$ and in the academy. In P-12, the research is primarily focused on the high school level, however. In an example of research on the high school level, Williams' (2009) goal was to use hip hop to engage students in a critical analysis of the effects of racial oppression. Using the Freireian problem-posing pedagogy to critically examine aspects of hip hop culture, Williams refers to his pedagogical strategy as the Critical Cultural Cypher. Williams argues,

The Critical Cultural Cypher can be used as a tool to help educators engage students in a dialogue about their understanding of hip hop culture, and help students see the world as a malleable and complex system, rather than seeing it as 
rigid and simplistic. Hip hop can be called upon to help students address systemic and structural domination... (p. 25).

By working co-intentionally with high school students, the teacher-researcher helped students develop individual counterstories as a work product/artifact. The counterstories demonstrated a well-articulated, critical analysis, which showed their understanding of how hip hop culture resists, reflects, and produces structural asymmetries (Williams, 2009).

Like Williams, Alim also implements Critical Hip Hop Pedagogies. Alim’s work is also with high school students, but he focuses on ways that language is used to both inhibit and promote agency and social transformation. Through Alim's research, students were charged with examining the speech/language usage of those immersed in hip hop culture, including the students themselves and hip hop celebrities. Students then had to critically examine the speech/linguistic patterns of themselves, members of their community, and prominent members of the hip hop culture. Then, students were required to analyze these patterns/styles and prisms through a critical race lens to gain an understanding of language's impact on either maintaining existing social order. Students walked away from the research with the experience of connecting the relationship between language, agency and oppression (Alim, 2007).

While the literature points to the research around the implementation of CHHP on the high school level, it also provides a limited number of exemplars of CHHP's implementation in the academy. Akom's (2009) 2-year long research in a California University was most exemplary. Akom (2009) engaged artists and scholars in the hip hop movement in conversation with college students. This focus group research centered 
around discussions of hip hop culture and its intersection with race, class, gender and sexual orientation. More specifically, the conversations centered around how hip hop might be used to drive teacher education programs towards a more social justice orientation.

\section{Culturally Relevant/Responsive Pedagogy: The Research}

In addition to highlighting exemplars of hip hop being used towards critical outcomes, the literature review also highlights other research that does not directly align with CHHP but still prioritizes the development of critically conscious students. Stovall's (2006) research, for example, was conducted with students in and urban high school social studies session and was aligned with the tenets of culturally relevant instruction. The research study caused students to examine hip hop lyrics from socially conscious rap artists and discuss social issues relevant to students' lives. They engaged around three areas: (1) the meaning of a just society, (2) the media's representation of celebrity and (3) how schools support the status quo.

Stovall's research is important because it shows how efforts to promote critical consciousness among students may come with its set of challenges. Stovall's case highlights the difficulty involved in teachers and researchers trying to have their finger on the pulse of an ever-evolving hip hop culture. The research suggests that teachers are not always the beholders of the cultural capital, and that fact may contribute to emancipatory aims in education not being realized. Stovall attempted to use conscious rap of artists like Mos Def and Public Enemy to engage youngsters in the hip hop generation; however, the music did not resonate with the students and the research did not meet it radical aims. 
Both Hill (2009) and Newman (2007) also met challenges as their research studies attempted to fuse hip hop culture and emancipatory education. Both studies were undergirded by the premise that integrating hip hop culture into K-12 education could have liberatory possibilities. Newman suggests that emancipatory hip hop pedagogy may be limited in effectiveness by the fact that students prefer gangsta rap, filled with narratives of materialism, sexism and black on black violence over more conscious forms of hip hop music. That is students align more the master narratives than the counter narrative. Hill, using rap texts to explore economic, social and political realities, found in his research indicates that hip hop pedagogy may alienate learners, including black middle class students (2009).

Rodriguez's emancipatory efforts were (2000) met with a different challenge. Is his research study, Rodriguez sought to engage a group of pre-service teachers in dialogue with black high school youth who identified themselves as hip hop lovers. Students used the Freireian problem-posing model to examine asymmetries in their school environment and shared the research, in a panel-style discussion, with pre-service teachers whose life experiences were markedly different from the students. This unique, two-way dialogue between students and preservice teachers was designed to privilege the voices of youth and to inform practice. However, the dialogue was wrought with challenges, including teacher chauvinism, as the preservice teachers did not view the students as legitimate sources of knowledge and judged the students' style of communication to be offensive (Rodriguez, 2000).

Along with the radical uses of hip hop culture in education, there is also a scant amount of research around ways that hip hop has been used as the liaison between 
students' home/peer world versus their formally academic world. While Morell and Adrade (2002) suggest that hip hop culture and music might be used for emancipatory purposes, their research was more centered around using hip hop music to connect students to the canons. One of their research findings around teaching technical literacy skills and competencies is that hip hop texts “...can teach a number of literary devices, including imagery, metaphor, irony, tone, diction, point of view, theme, plot, motif, and character development” (p. 89). In their research study Morell and Adrade (2002) developed a unit they created had three non-content-related goals objectives. While the first two goals - building academic skills and transferring skills onto canons - are not radical, there was a peripheral goal of having students use a critical lens critique the messages put forth by popular hip hop culture (Morell \& Adrade, 2002).

The Schooling Ourselves initiative provides another example of using hip hop culture to engage students and more deeply connect them to schooling experiences. The initiative itself is designed to scaffold hip hop culture into K-12 classrooms by connecting hip hop culture (specifically lyrics/text) to Pennsylvania state standards in English Language Arts. Teachers participated in workshops designed to motivate and encourage teachers to implement HHBE. The workshops built off of the content and strategies advocated by Do the Knowledge: A Standards-Based Hip Hop Learning and Curriculum Guide (Irby, 2006). The significance of the study is that it exposed hip hop culture to a larger audience of teachers. While most hip hop research is conducted by teacher-researchers, in this research study, Irby and Hall (2011) sought to show that there is a large group of teachers who may integrate hip hop into the classroom but are not compelled to share the results in scholarly publications. 
The research showed that even the less radical attempts to integrate hip hop culture into schools may present challenges. In "The Tale of the Talent Night Rap: HipHop Culture in Schools and the Challenge of Interpretation," researcher Brennan Low (2010) suggests that little attention has been paid to the inevitable clashing of hip hop culture with dominant school paradigms. Low's research study underscores concerns about hip hop causing a moral panic among school officials (Alverez, Jennifer \& Margaret, 1999). His research suggests that the concern of issues of sexuality, profanity, violence and drug usage inhibits hip hop culture's entrée into institutions of education, especially K-12 education. The hip hop drenched talent night was met with much difficulty as a result of the dominant values clashing with the knowledge and truths embedded in hip hop culture.

\section{Hip Hop in Extracurriculars and Therapeutic Interventions: The Research}

Along with research studies that explore the integration of hip hop into both K-12 and the academy (with both transformative and less radical goals), there are also research studies that speak to hip hop being used as a legitimate intervention tool or in after school programs. Intervention efforts and after school programs are mentioned separately in this literature review because they are not necessarily implemented by certificated teachers or college/university instructors.

In an eight week intervention program and using the Nguzo Saba as the value orientation, Abdul--Adil Pratt, Watts (2002) conducted research with a group of black high school aged males they referred to as the Young Warriors. The participants in this rites of passage intervention were referred to as Young Warriors because the warrior is idealized as a man aggressively and selflessly advocating for justice. Through a critical 
examination of hip hop culture through music videos and song lyrics, Young Warriors were to gain a sense of critical consciousness, media literacy and socio-political development. Students read videos in the Freireian sense, deconstructing messages of materialism, excessive violence, drug abuse, homophobia, hypermasculinity and misogyny. Students should walk away from the intervention with a heightened sense of how the music industry and they personally are complicit in the oppression of themselves and others. As a result of this intervention experience, the young black warriors should be, not just critically conscious, but engaged in action that interrupts the status quo (2000). Ultimately, the researchers' goal is to use this and similar research to develop a comprehensive set of hip hop-drenched interventions that equip black males with the skills and mindsets to be activists committed to social justice.

In their research study, Kobin, C \& Tyson, E. (2006) also used hip hop culture as an intervention. Their research goal was to use hip hop in therapy to help students of color develop empathy. They operated from the premise that hip hop, as a tool for selfexpression, can have therapeutic value. Hip hop can be a psychic salve. In the research, first, students examined socially conscious hip hop lyrics to engage in a discussion about the realities of their current lives. Then, the researchers used this dialogue to assess client values and provide support to clients to develop self-actualization roles. Their research suggests that culturally responsive therapists can engage students in a dialogue around hip hop in a way that accomplishes four general goals: (a) increases self-efficacy; (b) develops a sense of collective responsibility; (c) reduces self-blame and (d) encourages personal responsibility (Kobin and Tyson, 2006). 


\section{Summary: Hip Hop Culture - History and Impact on Education}

A synthesis of the literature and research around hip hop culture and its impact can be captured using a few major themes as a guide. First, hip hop culture, created from the genius of marginalized urban youth in New York City, is arguably one of the most impactive cultural movements in the last 30 years. Also, hip hop culture has played a role in creating a politically aware and politically active cadre of individuals and collectives. Through both the music and through organizations like the Hip Hop Summit Action Network and groups like Public Enemy, hip hop culture has inspired political action and social critique.

Finally, hip hop culture has been infused into classrooms across grade level spans and for multiple purposes. While hip hop has been used in education to connect students to the status quo of the canons, it has also been used to move students and teachers towards emancipatory, status quo-disrupting actions. Also, though hip hop culture has evidenced itself in America's schools and in some after school activities, the literature specifically around radical educational reform efforts that privilege, the voices, perspectives, and cultural capital of members of the hip hop generation is limited. This research attempts to provide additional research. Next, however, this literature review will explore CRT, the theoretical framework undergirding this research.

\section{Critical Race Theory (CRT)}

Using a critical lens, this research privileges the voices of a subgroup of the hip hop generation: the OGs. The primary conceptual framework undergirding this study around black males, race, hip hop culture and education is Critical Race Theory (CRT). A broad-based response to address the systematic marginalization 
and oppression of people of color, CRT is forged from a synthesis of critical thought in law, sociology, history, women studies and ethnic studies. Specifically, CRT emanated from scholars such as Derrick Bell and Alan Freeman, who suggested that Critical Legal Studies (CLS) scholarship and movement had a major limitation (Delgado, 1995; Ladson-Billings, 1997). The pair of scholars applauded the fact that CLS critiques the legal system and its role in naturalizing and legitimizing oppressive infrastructures; however, they contend that CLS is unable to propose transformative strategies because it ignores the centrality of race and racism (Delgado, 1995; Ladson-Billings, 1999). Solórzano and Yosso (2002) contend that CRT situates people of color in the center of research and gives them both voice and agency. Social reconstruction is CRT's goal, as it is a theory "of social transformation wherein knowledge is generated specifically for the purpose of addressing and ameliorating conditions of oppression, poverty, or deprivation" (Lincoln, 1993, p. 33).

Five broad premises form the foundation of the CRT framework. First is the primacy of racism and its intersectionality with other forms of marginalization. When examining issues around equity and agency, the impact of race and other lines of differences should be considered. Second, CRT challenges the seemingly neutral and objective dominant paradigms that support the status quo of racial oppression. Next is the social justice-oriented action component of the orientation. That is, those who align with CRT should promote actions that lead to the elimination of racial inequality. Fourth, CRT proponents recognize the import of culturally-specific experiences, perspectives of truth, and ways of knowing. Generally, this cultural wealth is captured in the form of 
counterstories. Last, the CRT orientation supports the notion that scholarship should be approached from a multi-disciplinary perspective. That is, when developing both theory and action to support critical thought and actions, a variety of academic resources should be accessed (Solorzano \& Yosso, 2002; Solórzano, 1997).

While CRT provides a general framework for analyzing, critiquing and dismantling racial inequality, authors Solórzano and Yosso (2002) suggest more education-specific addendums to the CRT lens. This research will be guided by the education-centric definition of CRT. Building on the five tenets of CRT, the educationspecific lens of the framework (a) contextualizes the experiences and (b) privileges the cultural capital of students of color. The researchers' nuanced CRT lens also challenges cultural deficit narratives about students by using counterstorytelling, oral traditions, media outlets, poetry and other cultural manifestations of people of color (Solorzano \& Yosso, 2002). Finally, the achievement of people of color is not gauged primarily by standardized test scores. Instead, education is assessed by its transformative outcomes. That is, education should have a social justice oriented outcome supporting the elimination of all forms of oppressions. In education should promote both agency and self-actualization opportunities for people of color (Matsuda, 1991).

\section{The Counterstory: A CRT Artifact}

Another crucial aspect of the CRT framework is the import of specific cultural knowledge, truths and experiences. Many cultural knowledges are typically interwoven into the fabric of the counterstory. The counterstory is a way that marginalized groups tell their collective stories, create their own truths and realities, and codify their cultural norms (Ladson-Billings and Tate, 1995; Solorzano and Yosso, 2001). Through parables, 
spoken word, art, music, dance, and other forms of expression, marginalized groups engage, describe and define themselves and the world. Gloria Ladson-Billings (1997) argues that "there are well-developed systems of knowledge, or epistemologies that stand in contrast to the dominant Euro-American epistemology" (p. 258). Hobbel and Chapman (2010) and Delgado (1989) contend that the counterstory challenges the more dominant truths, knowledge and frameworks.

For dominant groups, the counterstory can cause a dissonance that questions their ethnocentric view of truth and knowledge (Delgado, 1989). Without the counterstory, argue Ladson-Billings and Tate (1995, p. 58), “Oppression is rationalized, causing little self-examination by the oppressor. Stories of people of color can catalyze the necessary cognitive conflict to jar dysconscious racism.” For marginalized groups, Finally, researchers Delgado (1989) and Lawson (1995) outline four broad outcomes of the counterstory: (1) they build a sense of solidarity within marginalized groups; (2) they challenge dominant mindsets by offering a different perspective through which to view the world; (3) they empower members of marginalized groups by sharing the worldviews and experiences of those who overcame similarly oppressive situations; (4) and they can demonstrate that a fusion of the story and reality can generate positive outcomes.

The counterstory is a literary framing of narratives that provide an insight into the epistemology of a marginalized group. They provide a vehicle for psychic selfpreservation and the reclaiming of a sense of agency systematically denied by structures of oppression (Delgado, 1989; Freire, 1970). Marginalized groups' collective strength is encapsulated in counterstories, as researcher Tara Yosso (2005) suggests. This collective strength is what Bourdieu and Passeron (1977) refer to as cultural capital. Cultural 
capital - also referred to as community cultural wealth by Yosso (2005) - consists of the knowledge and competencies needed to successfully navigate in a particular culture.

\section{Conclusion}

For this research study, Chapter 2 has three broad goals. First, the literature review explores hip hop culture, discussing its origins, outreach and role as a sociocultural movement with both strengths and limitations. Second, the literature review explores the research around hip hop culture's purposeful infusion into schooling experiences. The literature divides the schooling experiences into to broad orientations: critical/antiracist and culturally relevant/responsive.

Last, this literature review outlines the tenets of Critical Race Theory (CRT) the primary framework undergirding this study around black males, race, hip hop culture and education. CRT is a lens that examines the ways that race, privilege, identity and power intersect to create material conditions. CRT is social justice oriented, in the sense that is promotes critique and action. Action is driven based on valuing the perspectives and cultural capital of the group being marginalized (Yosso, 2005). While the overarching conceptual framework is Critical Race Theory (CRT), the counterstory - the collective voice of an outgroup - is a specific concept within the CRT framework that is highlighted in the literature as well. 


\section{CHAPTER 3}

\section{DESIGN AND METHODS}

\section{Introduction}

The purpose of this narrative study is to explore the schooling experiences of the OGs, a group of black males who serve as the elder statesmen of the hip hop generation. This study explored the ways that the participants align with and/or challenge dominant narratives around black men in the hip hop generation. Also, this study explored the ways hip hop culture has impacted the research participants, especially focusing on the ways it has helped to define their black masculinity, inspired, informed and troubled them. The study also explored the implications the findings might have for educational reform and leadership.

The qualitative methodological approach is most appropriate for this research study. The qualitative methodological approach is inductive and emergent, in the sense that learnings are gained through the experiences of the participants (Mertens, 2005). Unlike the quantitative approach, the qualitative approach does not require a formal hypothesis before beginning research. In a qualitative approach, the subjectivity of the researcher is an integral component of the study (Miles \& Huberman, 1994). The researcher's personal and professional experiences help to inform and broadly define the themes and knowledge that emerge from the research (Mertens, 2005). This personal or professional connection is explained in Bernal's (1999) notion of cultural intuition. He states that cultural intuition "extends one's personal experience to include collective experience and community memory, and points to the importance of participants' engaging in the analysis of data" (pp. 567-568). In this study, my membership in the OG 
cohort suggests that cultural intuition and subjectivity will impact the research outcomes. Because I am a black male, college graduate who first experienced hip hop culture as a pre-teen, and also because of the level of research I have invested in the topic, I have a strong sense of the orientations of the research participants. This will allow me to explore topics and perspectives that might otherwise be ignored, and this intuition adds depth to the research.

In the remainder of this chapter I will, first, provide an overview of the problem statement and research questions. Next I will review the methodological dimensions of Critical Race Theory and counterstory (discussed in more detail in Chapter 2) that undergird the study. Then, I will outline the research design and methods, including the setting, participant selection, IRB and ethical procedures, data collection, and data analysis. Finally, I will include a discussion of researcher reflexivity and methods for ensuring trustworthiness.

\section{Statement of Problem}

Hip hop culture has been in America's bloodstream for over 30 years and has been integrated into education in a number of iterations; however, there is a gap in the research as it relates to using the values, norms and knowledge of the hip hop generation and how they might inform educational reform (Irizarry, 2009; Keyes, 2002). Many researchers argue that educational reform cannot take place without privileging the perspectives and cultural capital of those who occupy the margins of society, especially people of color (Ladson-Billings, 1997; Hollie, 2001). Researchers also argue that educational reform efforts must consider contextual factors that influence educational outcomes. To that point, William Foster suggests that, "When we divorce education from other contexts that 
influence and are influenced by broader context, we limit our ability to develop a deep understanding" (p. 19). Hip hop culture is one of those contextual elements that has influenced youth since the late 1970s.

Referred to as "black folk's CNN" by hip hop legend KRS-One (Ridenhour $\&$ Steiner, 2000), hip hop culture is a contextual lens through which many youth and adults view the world. As researcher Izzary (2009, p. 511) states, "Understanding hip hop culture gives us insight into the most powerful force in the lives of urban youth and can be used to further engage students instead of marginalizing them." Irizarry further puts the import of hip hop into perspective when he says, "Although rarely tapped as a resource, urban youth have much to teach us about life, in general, and teacher education more specifically" (p. xx).

The problem this research attempts to address is the marginalization of a specific group within the hip hop generation: black males. The voices of black males in the hip hop culture have not been specifically privileged in scholarly conversations related to education reform. Black males, the same cohort absent from research literature, are also the same cohort that continues to underperform in classrooms. In my Midwestern hometown, for example, approximately 2 of 5 black males graduate from local high schools (Schott Foundation for Public Education, 2010). According to data gathered from the 2009 National Assessment of Educational Progress test, a mere 1 out every 10 eighth grade black males reads at a level of proficiency (National Center for Education Statistics \& United States Office of Educational Research and Improvement, 2009). Further, according the Schott Report, (Schott Report for Public Education, 2010), black 
males are four times less likely than their white counterparts to take advanced placement classes.

This study privileges the voices of a cadre of black males who identify as being members of a marginalized cadre, the hip hop generation. In this research study, these veterans of the hip hop generation pose a set of critical perspectives and best practices that support education reform efforts. Researcher and cultural critic Michael Eric Dyson voices a concern about ignoring the voices of the hip hop culture, highlighting hop culture's impact on youth. He says, Given its universal popularity and troubling effects, hip-hop is vital cultural language that we had all better learn. To ignore its genius, to romanticize its deficits, or to bash it with undiscerning generalities is to risk the opportunity to engage our children about perhaps the most important cultural force in their lives (Dyson, 2001, p. 138).

\section{Research Questions}

The research questions for the study are:

1. What are some of the schooling experiences of black men in the hip hop generation?

2. As a cultural force germane to the lives of many students of color, how has hip hop culture influenced the educated cadre of the OGs of the hip hop generation?

3. In what ways do black men in the hip hop generation represent a counter narrative to the dominant narrative of U.S. schooling experiences and outcomes for black men?

4. In what ways do these same men contribute to the master narrative around black male in the hip hop generation - in either mindset or action? 


\section{Research Methodology: Critical Race Theory and Counterstory}

The methodological underpinnings of the study are Critical Race Theory, and particularly counterstory as an approach within CRT. As explained in Chapter 2, a more nuanced, education-centric application of CRT influenced all phases of this study. Building on the five tenets of CRT, the education-specific lens of the framework contextualizes the experiences of people/students of color within their racial, genderracial, class and individual identities and privileges the notion that students' race, genderracial and class intersections can produce cultural capital (Smith et al, 2007). The education-centric CRT lens also challenges cultural deficit narratives about students by using counter-storytelling, oral traditions, media outlets, poetry and other cultural manifestations of people of color (Solorzano \& Yosso, 2002; Chapman and Hobbel, 2007). Finally, from this CRT perspective, the achievement of people of color is not narrowly defined by their achievement on standardized tests. Instead, education is assessed by its transformative outcomes. This form of education -- which is sometimes referred to as empowering education - is part of a larger social justice movement (Shor, 1992; Smith et al, 2007). This perspective argues that, using a broad range of disciplines, education should promote both agency and self-actualization opportunities for people of color (Freire, 1970; Matsuda, 1991; (Smith et al, 2007). From a CRT orientation, educational policies and practices that support the development of performance gaps must be challenged.

Centralizing and authentically valuing the lived experiences of people of color is an essential component of Critical Race Theory framework. The counterstory is a way that marginalized groups (a) explore their lived experiences, (b) create and share their 
own truths and realities and (c) codify their cultural norms (Ladson-Billings and Tate, 1995; Chapman and Hobbel, 2007). The counterstory challenges majoritarian stories truths and knowledge that support hegemony by normalizing inequalities based on race and class. Delgado (1995) suggests, "Majoritarians tell stories too. But the ones they tell - about merit, causation, blame, responsibility, and social justice -- do not seem to them like stories at all, but the truth" (p. 666).

Delgado goes on to suggest that counterstories challenge "the bundle of presuppositions, perceived wisdoms, and shared cultural understandings persons in the dominant race bring to the discussion of race" (p. 462). Finally, researchers Delgado (1989) and Lawson (1995) outline four broad outcomes of the counterstory: (1) they build a sense of solidarity within marginalized groups; (2) they challenge dominant mindsets by offering a different perspective through which to view the world; (3) they empower members of marginalized groups by sharing the worldviews and experiences of those who overcame similarly oppressive situations; (4) and they can demonstrate that a fusion of the story and reality can generate positive outcomes.

The methodology undergirding this research privileges the counterstory of black male members of the hip hop generation, the OGs. This study employed the composite counterstorytelling method as outlined by Tara Yosso (2006). Yosso outlines four steps to employing the methodology: (1) exploring research and literature from secondary sources, primary sources, social sciences, humanities and legal scholarship (2) conducting research with a group of participants (3) deliberately privileging the researcher's personal experience; and (4) connecting the researcher's professional 
experiences to the study. The product of the research methodology is the creation of a narrative that highlights emergent themes and Sam experiences of the respondents.

In alignment with the composite counterstorytelling method, I began by conducting research around the history, development and impact of hip hop culture. Then, I reviewed the literature relevant to hip hop culture's infusion into P-20 education. After reviewing research, artifacts and scholarship, I used the focus group interview to explore the stories and perspectives of the research participants. Next, I used both my personal and professional stories to contribute to the breadth and depth of the data analysis. Finally, I explored the themes emerging from the counterstories and created a narrative that captures those themes and Sam experiences.

\section{Research Design}

The primary design method - the specific means of gathering data - is the focus group. The focus group method is appropriate for this study for at least two reasons. First, the focus group is guided by the interaction of the respondents and not the researcher. As Kruger \& Casey state, "Focus groups, in essence, are group interviews that rely, not on a question-and-answer format of interview, but on the interaction within a group" $(2000, \mathrm{p}$. 213). Second, the focus group allows for the exchange of divergent ideas. As Mertens (2005) states, "The focus group interaction allows the exhibition of a struggle for understanding how others interpret key terms" (p.245).

\section{Participant and Sample Selection}

For this bounded study, the population is black males between the ages of 35-45 who were raised in a Midwestern urban center and have all pursued at least an undergraduate degree. This population was chosen for two reasons germane to this 
research around hip hop culture, black males and schooling. The first reason the participants were chosen is that they have witnessed the development of hip hop culture for at least 25 years, which suggests that they may have a well-informed perspective around the culture's import and challenges. This generation of black males was first exposed to hip hop culture through artists/groups such as the Sugarhill Gang, Grandmaster Flash and the Furious Five and Run DMC and through TV movies and shows like Yo!, MTV Raps, Breakin' and Beat Street. In a sense, this group grew up with hip hop culture as an important backdrop.

The second reason the participants were chosen for this study is because they navigated challenges and persisted through college. As educational organizations throughout the country strive to support black male persistence through college (e.g., Coalition of School Educating Boys of Color, College Bound, Inroads), a great number of black males, nonetheless, disproportionately occupy space in jails and prisons instead of in colleges and universities. Over the last two decades, three times as many black males were added to state and federal prison systems as were added to higher education roles (State estimates of prison populations by the Justice Policy Institute, and National estimates by the Bureau of Justice Statistics 2001, 2000; National Center on Institutions and Alternatives, 2001; National Center on Education Statistics, 2001).

A stratified purposeful sample strategy was used in this study, as it "illustrates subgroups and facilitates comparisons" (Miles \& Huberman, p. 28). Not only did this study explore the collective counterstories of a subgroup of the hip hop generation (the OGs), but it also explored the ways that narratives might differ based on one's personal experiences and beliefs, level of academic preparedness and engagement with hip hop 
culture. The stratified purposeful sample shows that hip hop culture is not monolithic, as it compared the voices of individuals who completed college, but who were dissimilar in a number of factors. Factors such as gang affiliation, racial composition of schools and colleges attended, family dynamics, academic tracking and religious exposure all impact the diversity of thought within the OG cohort.

In total, there were eight participants in the focus group. See Table 5 below for a brief biography of each of the participants. The criteria for selection are as follows:

- Each participant has a baccalaureate degree, at minimum.

- Each participant has self-identified as a hip hop head (one who has a strong affinity for hip hop culture) and as an OG member of the hip hop generation.

- Each participant is a native of the Midwest Metro area.

\begin{tabular}{|c|c|}
\hline \multicolumn{2}{|c|}{$\begin{array}{l}\text { Table } 6 \\
\text { Research Participant Information }\end{array}$} \\
\hline Pseudonym & General Description/Biography \\
\hline Ben & $\begin{array}{l}\text { - Native of East St. Louis, Illinois } \\
\text { - Graduated from all-black high school "most likely to succeed" } \\
\text { - Undergraduate degree from major Midwest university } \\
\text { - } \quad \text { Received full academic scholarships for both undergraduate and } \\
\text { graduate studies } \\
\text { - Raised in working class home with mother and stepfather } \\
\text { - Has worked in education for } 20 \text { years, more than half as a school } \\
\text { leader }\end{array}$ \\
\hline Ty & $\begin{array}{l}\text { - } \text { Native of East St. Louis, Illinois } \\
\text { - Graduated from all-black high school } \\
\text { - } \text { Began undergraduate career at large university but transferred to a } \\
\text { - } \text { small Historically Black College/University (HBCU) } \\
\text { - } \text { Received full academic undergraduate scholarship } \\
\text { - } \text { Raised in two-family household, with both parents being educators } \\
\text { - } \quad \text { Currently employed as a school principal }\end{array}$ \\
\hline George & $\begin{array}{ll}\text { - } & \text { Native of East St. Louis, Illinois } \\
\text { - } & \text { Graduated class valedictorian from all-black high school }\end{array}$ \\
\hline
\end{tabular}




\begin{tabular}{|c|c|}
\hline & $\begin{array}{l}\text { - } \text { Began undergraduate career at large university but transferred to a } \\
\text { small Historically Black College/University (HBCU) } \\
\text { - } \quad \text { Received full academic undergraduate scholarship } \\
\text { - } \quad \text { Completed master's degree } \\
\text { - } \quad \text { Raised in one-parent home in housing projects } \\
\text { - } \quad \text { Member of nationwide street gang } \\
\text { - } \quad \text { Currently employed as a school principal }\end{array}$ \\
\hline Don & $\begin{array}{l}\text { - Native of small town outside of East St. Louis, Illinois } \\
\text { - } \quad \text { Graduated from predominantly white, lower working class high school } \\
\text { - } \quad \text { Undergraduate degree from major Midwest university } \\
\text { - } \quad \text { Completed master's degree } \\
\text { - } \quad \text { Raised in middle class, two parent household } \\
\text { - } \quad \text { Currently employed as a higher education administrator }\end{array}$ \\
\hline $\mathrm{Ab}$ & $\begin{array}{l}\text { - } \text { Raised in suburban Illinois town } \\
\text { - Graduated from predominantly white, middle class high school } \\
\text { - Undergraduate degree from mid-sized Midwest university } \\
\text { - } \text { Raised in middle class, single parent household } \\
\text { - Currently self-employed financial planner }\end{array}$ \\
\hline Todd & $\begin{array}{l}\text { - Native of East St. Louis, Illinois } \\
\text { - } \text { Graduated from all-black high school } \\
\text { - } \quad \text { Undergraduate degree from HBCU } \\
\text { - } \quad \text { Completing graduate degree } \\
\text { - } \quad \text { Raised in working class, two parent household } \\
\text { - } \quad \text { Currently employed by large financial corporation }\end{array}$ \\
\hline Sam & 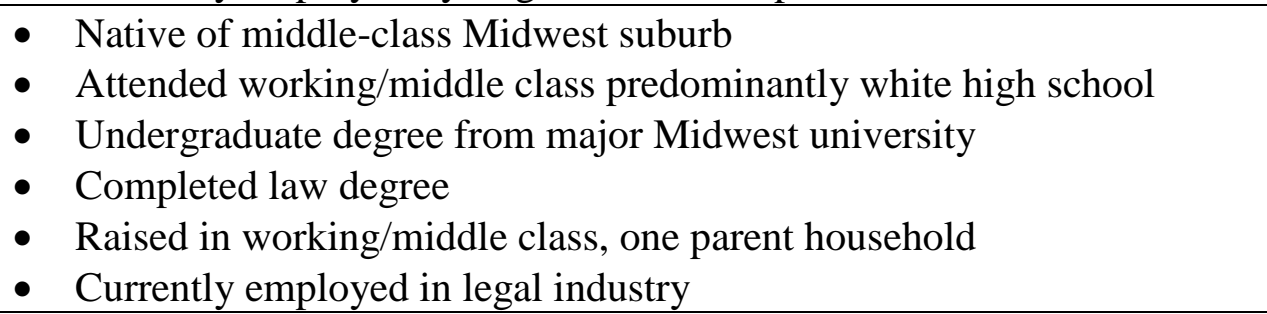 \\
\hline LT & $\begin{array}{l}\text { - } \text { Native of middle-class Midwest suburb } \\
\text { - Attended working/middle class predominantly white high school } \\
\text { - } \quad \text { Undergraduate degree from mid-sized Midwest university } \\
\text { - } \quad \text { Raised in middle class, two parent household } \\
\text { - } \quad \text { Currently employed with Fortune } 500 \text { company }\end{array}$ \\
\hline
\end{tabular}

\section{Ethical Considerations, Consent and Confidentiality}

In an effort to consider the ethical concerns of this study, all guidelines as defined by the Institutional Review Board (IRB) as well as any other ethical principles presenting guidelines of performing study on human subjects (Creswell, 2009) were adhered to. In 
addition, other methods were employed to ensure the integrity of this study. Those are described below.

All participants were given the opportunity to read a brief description and purpose of the study and asked to sign and submit their consent forms before participating in the study. All participants of the study were informed of their right to withdraw from the study at any time without giving an explanation or having a penalty assessed. If that happened, their responses would not have been included in the analysis.

Also, to ensure credibility of the data, member checking was conducted, as recommended by Creswell (2007). He suggests that member checking provides respondents the opportunity to assess adequacy of data and to correct errors and misinterpretations. After synthesizing the thoughts of each participant, a copy of the notes was forwarded to each participant. They were given the opportunity to edit, confirm and challenge the summaries. Each provided a confirmation that they had reviewed the notes and were given an opportunity to make any adjustments.

All data collected regarding the participants is confidential, and any responses that might reveal a person's identity have been removed. Also, pseudonyms are used to further mask identities. Video and digital audio files were transferred onto my laptop and can be accessed only by password. The data management login and password are safeguarded and accessible only by the researcher. Data will be transferred onto a flash drive and removed from the laptop hard drive exactly one month after the dissertation is approved. Data will then be locked away for seven years after the dissertation has been approved, as required by IRB regulations. 


\section{Data Collection}

The researcher conducted a focus group interview with the OG respondents. This research complied with all of the technical best practices, as summarized by Creswell. Creswell (2007) contends that strong interviews have the following general characteristics:

1. Purposeful sampling.

2. Deliberation around the selection of the most appropriate interview format.

3. Use of adequate recording resources

4. Design and use of an interview protocol

5. Pilot testing and a refining of interview questions

6. Thoughtful consideration of the appropriate place for interview

Through the focus group design method, participants engaged in dialogue in response to structured interview questions and prompts, sometimes followed by probing and/or clarifying questions. Using open ended questions and prompts, the goal of the emergent dialogue was two-fold. First, the questions and prompts sought to reveal the multilayered narratives, perspectives and voices of the OGs. Second, in the data analysis component, the goal was to synthesize and make sense of those stories by exploring the commonalities and the nuanced differences in the perspectives and cultural knowledge of this OG cohort.

Particularly, the focus group discussion explored discourses around the intersections of race, race-gender, masculinity, class, hip hop culture and education. Guided by an education-centric CRT lens that uses the intersection of race, race-gender 
and class as a tool to examine and challenge educational inequity, the discourse was centered around the following broad themes:

1. Impact of Race, Gender and Class on Educational Outcomes

2. Education's Role in Empowering Black Males

3. The Import of Transformative Educators

4. Role of Hip Hop Culture in the Lives of Black Males The data collection component of this study, the focus group interview, was designed to generate the discourses, or narratives related to schooling experiences, hip hop culture, race and black masculinity. The group of 8 participants (including myself) assembled at 8:30 a.m. on January 26, 2013. The dialogue took place at an elementary school conference room and lasted approximately 7 hours, with lunch built in. As the facilitator/participant, I posed twelve broad questions, but also posed a number of follow up and clarifying questions/comments as well. The participants offered their perspectives and thoughts as they deemed appropriate. The primary questions that guided the focus group are in Table 7. 
Table 7

Focus Group Guiding Questions/Statements

1. From my point of view, hip hop culture should...

2. From my point of view, I'm an OG because...

3. What is good about hip hop culture?

4. What is concerning, troubling or damaging about hip hop culture?

5. What does it mean to be a man in hip hop culture?

6. What's up with homosexuality in hip hop culture?

7. What was one of the major challenges you had to overcome in school?

8. How did your pre-college experiences prepare you for college? What, if anything, was missing from your experiences?

9. In your educational experiences, who were the educators that most positively impacted you? Is there a particular experience or story that exemplifies the impact?

10. What books or films have influenced your life?

11. If you could recommend a book for a high schooler or college student to read, what would it be?

12. If you were to give your $8^{\text {th }}$ grade self a piece of advice, what would it be?

Following the data collection stage of the research - the focus group - I

conducted the data analysis. As its final outcome, the data analysis component of this research was designed to produce a particular synthesis of the narratives - a composite counterstory.

\section{Data Analysis}

As Creswell (2007) states, "The data collected in a narrative study need to be analyzed for the stories they have to tell, a chronology of unfolding events, and turning points or epiphanies" (p. 155). Before executing the analysis process, in alignment with the composite storytelling methodology, there must first be a review of relevant literature and data. For this study, I conducted a comprehensive review of the literature related to the intersections of hip hop culture, black males, and education. The second stage of the counterstorytelling methodology is conducting research with a group of participants. For this research, the focus group interview serves as the research design tool. In addition, the 
composite counterstorytelling methodology requires that the research recognizes the personal experiences of the researcher. Admittedly, my voice and experience are infused through each section of this study - including the introduction, the literature review, and the methods sections.

With regard to the data analysis in a narrative study, Ollerenshaw and Creswell (2002) and Clandinin and Connelly (2000) outline two elements Sam to narrative analyses: (1) collecting stories from dialogue with the study participants and (2) retelling stories by synthesizing themes and learnings. Incorporating researcher voice and interview setting are crucial to narrative analyses as well. Before synthesizing multiple stories and creating the composite counterstory, researcher Carol Gilligan (2003) suggests using the voice-centered relational method of data analysis first. This method provides a means of helping the researcher reflect on the presence and impact of his voice in the research. The voice-centered relational method is comprised of distinct actions centered around the reading and interpretation of the qualitative interview data.

In alignment with the voice-centered relational method of data analysis, first, I reviewed the interview data/research notes in an effort to explore the ways my voice and perspectives might have influenced the focus group. Gilligan (2003) calls this finding one's self in data. To find one's self in the data means that the researcher looks to differentiate his perspectives and stories from the respondents' perspectives. After reviewing the initial notes to locate my presence in the research, I then executed the next step - a reader response action, as recommended by Gilligan (2003). Specifically, I carried out a written brain dump, comparing my portfolio of perspectives and experiences with the respondents' perspectives and multiple voices. That is, once I read through the 
entire portfolio of responses, I wrote down my overall thoughts and responses. Then, in the next step, I followed the protocol by re-examining the notes, paying attention to the ways I applied emotion and intellect to the dialogue (Brown, 1994).

The final stage of the voice-centered relational method involves a two-column comparison strategy (Brown, 1994). In one column is the respondents' key statements and phrases, and in the other column, the researcher reacts to and interprets respondents' responses. Before creating the narrative using the emergent themes, I executed, this last step in the voice-centered relational method protocol.

In a chapter in their book entitled "On the Listening Guide: A Voice-Centered Relational Model," researchers Brown and Gilligan state, the voice-centered relational method of data analysis helps in "situating ourselves socially and emotionally in relation to respondents," an important element of reflexivity (1992, p. 169). This practice of situating one's self against the respondent is commonly referred to as locating. Locating one's self necessarily requires that the researcher thoroughly examines the assumptions and challenges that accompany his ontological and epistemological perspectives.

When examining my potential blind spots or assumptions, I had to consciously and consistently reflect on the ways that my intimate knowledge of the participants might shape the research outcomes. Toward that end, I used the voice-centered relational method. With regard to blind spots/assumptions, one of the assumptions I made initially was that all of the selected research participants were hip hop culture heads. That is, I assumed that the participants had a strong affinity for hip hop music and hip hop culture. As two of my initial participants professed not to be hip hop heads, they were not a part of this research study. I also assumed that, because I know the research participants 
intimately, we would all have the same general perspectives around hip hop culture, black males and schooling. I was incorrect in that assumption.

After this researcher explicitly situated himself in the research using the voicecentered relational method, I then used categorical aggregation to establish themes and patterns. Once I developed themes and patterns, I used those to create a counterstory, a narrative that illustrates the collective counterstories and perspectives of a group of black men growing up in the hip hop generation.

Once I executed the voice-centered relational method of analysis, I created a composite counterstory in a manner that other researchers have. Smith, Yosso and Solorzano (2007), for example, use the composite counterstorytelling methodology to guide their research around racial primes and the experiences of black males in higher education. Through a focus group interview approach, the researchers collected data from black males at four universities for the purpose of exploring ways that that the dominant discourse around black males impacted their college experience in both social and academic settings. The emergent themes, Sam experiences and epiphanies were expressed in the form of a counterstory, a narrative whose themes should be compared against the dominant discourses. In the findings section of the researchers' published work, they synthesize their learnings and surmise their contribution to the body of work around black males in education. While some of their findings point to changing mindsets and practices that promote marginalization, they suggest specific programmatic changes as well (Smith et al, 2007). The authors' research, as is mine, is advocacy/participatory in orientation, as it champions the use of stories as a tool of agency and liberation (Mertens, 2005). 
For this research study, I used the late Tupac Shakur as a central figure in the counterstory. Emcee, actor and social activist, Tupac is cultural icon and archetype of masculinity in hip hop culture Tupac was known for being just as misogynistic and nihilistic and he was for being critically conscious, thoughtful and social justice-oriented. He represents the conflict that DuBois unearthed in Souls. In this research, similar to the work of Smith, Yosso and Solorzano (2007), I unearth the emergent themes of the focus group by creating a scenario where a central character (in this case, Tupac) engages the research participants in an exploration of those themes. Said in another way, instead of discussing emerging themes in the more traditional research analysis formats, this research discusses the emergent themes in a fictional conversation between the research participants and the late Tupac Shakur.

\section{Researcher Reflexivity}

Pezella et al (2012) suggest that the researcher is the "primary instrument in qualitative review studies" (p. 165). Denzin and Lincoln (1994, p. 503) point out egoistic aspect of qualitative research, arguing that a research's goal “...is always selfpresentation" and that there is a "writer's self-presentation in the text." Because the researcher is essentially a qualitative data collection instrument, his epistemological and ontological perspectives have the potential to impact the research study (Alvesson and Sköldberg, 2000; Creswell, 2007; Mertens, 2005). Specifically, the researcher's epistemological and ontological lenses influences the way researchers analyze and interpret data.

In its most general terms, reflexivity is the researcher's acknowledgement of the presence of self in qualitative research. More specifically, reflexivity is the practice of 
explicitly recognizing and discussing the ways a researcher become might contribute to the research process. Reflexive data analysis recognizes subjectivity and rejects the notion that data analysis must be a "series of neutral, mechanical and decontextualized procedures that are applied to the data and that take place in a social vacuum" (Mashow do yoon, 1996, p. 7). As Shacklock and Smith (1998, pp. 6-7) indicate, For us, being reflexive in doing research is part of being honest and ethically mature in research practice that requires researchers to `stop being "shamans" of objectivity.' To not acknowledge the interests implicit in a critical agenda for the research, or to assume value-free positions of neutrality, is to assume `an obscene and dishonest position'.

Reflexivity is crucial to a study such as this one in which the researcher shares many aspect of identity and experience with the participants. In Chapter 1, I presented my personal biography as a way to begin the study by foregrounding my consciousness of reflexivity. Throughout the study I continued to reflect on how my identity, biography, and complex positionality as both a member of the hip hop generation and a researcher/doctoral student affected data collection and analysis. I personally selected every participant in the study and have considerable knowledge of each participant's personal and professional experiences, having spent numerous hours with them, discussing issues around race, hip hop culture and education. This was both a strength and a potential challenge for me, as I had deep contextual knowledge to bring to the 
interviews but may have made assumptions that foreclose certain lines of questioning. Strategies for enhancing reflexivity and trustworthiness I employed included member checking, journaling throughout the research process and peer debriefing periodically with someone who understands the topic of the study and can act as a critical friend. 


\section{CHAPTER 4}

\section{FINDINGS}

\section{Introduction}

In this chapter, the findings from the narrative study - exploring the connections between hip hop culture, black males and their schooling experiences - will be presented in the form of a composite counterstory, which synthesizes the major themes emergent from the focus group. Similar to the work of researchers Solorzano and Yosso, as detailed in the article, "A Critical Race Counterstory of Race, Racism, and Affirmative Action" (2002), this research created a counterstory centered around historical figures. While Solorzano and Yosso write a counterstory with historical figures Thurgood Marshall and Ruby Bridges as central characters, this study has Tupac Shakur as one of its central characters. The emergent themes and findings from the research are embedded in the fictional conversation between Tupac and the research participants.

Tupac is significant to this study because he embodies the duality and complexity that is part of hip hop culture's makeup. While he was criticized by for popularizing and promoting troubling narratives around black males in the hip hop generation, Tupac was also recognized as a genius and cultural icon. Tupac is a part of the bricks and mortar of hip hop culture. As Michael Eric Dyson (2001, p. 107) states,

Tupac is not likely to fade from cultural view anytime soon...Above all, Tupac was a transcendent force of creative fury who relentlessly articulated a generation's defining moods-its confusion and pain, its nobility and courage, its loves and hates, its hopelessness and self-destruction. He was the zeitgeist in sagging jeans. 
The setting of the counterstory is the fictional Museum of Hip Hop Culture and History. The fictional museum is grounded in cutting edge technology, so museum visitors are able to put on a set of headsets and a pair of goggles to take a realistic-feeling time travel through various significant events in hip hop culture's sociohistorical evolution. Led by Tupac, the research participants take a tour through the Museum of Hip Hop Culture and History as first-hand observers. In addition, Tupac engages with the OGs around issues of hip hop culture, masculinity and schooling. From this conversation, a number of themes emerge (the themes are what emerged from the focus group interview).

\section{Welcome to the Museum: The Fictional (Counter) Story Begins}

Ben: As we enter the hallway of the Museum of Hip Hop Culture - which is located in the heart of the Bronx - events, people and places described in the entering hallway look very familiar to us. The strangest part is that everything has a 3D realness to it, which makes us feel like we are in multiple points in history simultaneously. It is one of the most guttural and strangest feelings I have ever had. It is now the 1950s, and we start off in the museum by walking through the dusty remnants of metal and concrete from the Bronx Bridge implosion that created the community that would birth hip hop culture. We see working class whites leaving in droves as the final stripes are being laid on the Bronx Cross Highway - the highway that gives them easy access to suburban enclaves (Bridger, 2011). Immediately after that, we see Afrika Bambaataa in Rucker Park in New York, standing with his signature sunglasses and Afrocentric attire, articulating the antiracist Zulu Nation philosophy. 
Then, we walk into another section of the museum and see hip hop culture securing its roots in the parks and street corners of the Bronx. While members of Bambaataa Zulu Nation are explaining their platform to tens of thousands of gang members, the breakdancers (also known as b-boys and b-girls) in competing Zulu cliques are battling against one another. While a deejay keeps the party rockin' till the break of dawn, the emcee Busy Bee was telling people to, "Throw your hands in the air...wave 'em like ya just don't care." The crowd is enthralled, waving hands and bobbing heads to the sampled beat of James Brown's "The Big Payback."

The next section of the museum takes us on a transatlantic flight to London, where get a chance to drink champagne with Princes Harry and William, along with PDiddy and Kanye West at a Princess Diana memorial concert. Feeling both exhausted and anxious, we enter the next gallery, and we are surrounded by a group of breakdancers who appear to represent various nationalities. Then the lights go dark.

When the lights come on, the date is September 7, 2006. We are in a car, leaving a Mike Tyson fight in Las Vegas. I realize we are riding with Suge Knight and Tupac Shakur. Suge is at the wheel and Tupac is on the passenger's side. As we jump into the vehicle, a car pulls up and guns ring out. Tupac is shot. As I stare at his chest wound and then notice his eyes staring off into space, I know he is dead. The killer points his gun at us, smirks weirdly, then decides not to shoot. With hearts crying out with fear and confusion, we are immediately transported to another part of the museum experience.

This time, still in shock from the Tupac killing, we are transported to LA for a party featuring hip hop icon Christopher "Biggie" Wallace. As Biggie performs, our adrenaline is high as we hear hip hop classics like, "One More Chance" and "Big Poppa." 
At the end of the concert, we are escorted out of the club with Biggie and Sean "Diddy" Combs. People do not know us, but they are asking us for our autographs. This is a great feeling. As we climb into Biggie's Blue GMC truck, something feels morbidly uncomfortable. In what seems like a second later, a man with a blue suit and red bow tie jumps out of his car at a stoplight and sprays our car with bullets. Amazingly, no one is shot - except Biggie. As he takes his last breath, I hear him say, "Save hip hop."

Our group is exhausted, scared and shocked as the museum tour continues. Next, we travel to the Jam Master Jay studios, where we listen to Jay talk about how his group, Run DMC, was able to help hip hop culture cross over into mainstream America when they produced the hit "Walk this Way" with the rock mega group Aerosmith. As he glowed in pride about being an ambassador for hip hop culture, Jay's friend walks in with shades and a hoodie pulled over his head. The friend, seeming nervous when he realizes Jay recognizes him, pulls out a semiautomatic weapon and shoots Jay at point blank range. As Jay falls to the floor, I immediately get sick all over the blood-stained carpet. The killer looks at me and says, "Snitches get stitches." For me, nothing else needs to be said. This leg of the experience ends. Again, I'm shocked, nervous and confused. The lights come back on.

On the final leg of the museum tour, we are ushered quickly to a small conference room called Hip Hop Halo. We are greeted by Tupac Shakur, who is seated at the head of conference room table, wearing a white tuxedo jacket, sagging Levis jeans, and black Michael Jordan sneakers. The conversation, or cypher, begins.

Tupac: What's up, OGs? I hope you enjoyed the tour. When I created this museum, I wanted the visitors to literally feel hip hop history. Now that you've toured the museum I 
want to talk to you. I'm impressed by you brothers because you have navigated the hood's potholes, graduated from college, and you still keep it real. In many ways, you represent the positive outcomes of the Civil Rights and Black Power Movements. To me, you are the true OGs. Because I've been off the scene for a few years now, can I ask you guys some questions? I really want to know about three major things:

1. Your vision for hip hop culture

2. Your analysis of hip hop culture, from a critical perspective

3. Your schooling experiences

I'm interested in hearing your stories because you are the OGs. You were around when hip hop culture got off the ground and you still embrace aspects of the culture today. Not only that, you are different kind of brothers. You went to college. I dropped out even though I was pretty smart (Kitwana, 2005). You represent a unique set of black men because some of you are lawyers, entrepreneurs, educators and middle level managers of major corporations. I want to hear about your schooling experiences and your thoughts about black masculinity as well, because I think classroom educators and educational leaders can be informed by hearing your voices, stories, and perspectives.

First, I really hope that you guys can share with me two specific pieces of advice. Both require considerable reflection. First, I would like you to pretend you could go back and talk to your eighth grade self. Based on what you know about the world now, what advice would you give to yourself? You know, a few young Gs come to the Museum, so, when they do, I will have some good advice for them.

Also, as you may or may not know. I love reading. I believe that literacy is one of the keys to empowering black males. I know some of you read about my history, so you 
know that both of my parents and many of my mentors were Black Panthers. They fed me books like Mao's Red Book, The Autobiography of Malcolm X and The Prophet. If you really read about me, you also know that a white woman, Leila Steinberg, was influential in my becoming a voracious reader as well. When I lived with her in Oakland with her, I consumed all kinds of books (as cited in Dyson, 2001). I want to know about the books that shaped your development and your voice. When school groups and other smart folks come to the museum, I'd love to share the books with them. In fact, I'm gonna put them in our gift shop.

So, let's go to the Cypher Room. As you know, cypher is very big in hip hop culture. Symbolically, the cypher represents a place where one puts his very best vocal skills on display. It's the wordsmith's playground. Let's go to the Cypher so I can hear your stories. Oh yeah, no worries. I know technology is big now, so feel free to use whatever means you like to get your story across. We have current and future technology. Once I hear your collective stories, I will synthesize them and create an exhibit for the Museum called, "College-Educated OGs."

Ben: We walk into the Cypher Room, it is filled with pictures, sculptures, and artifacts of men with gift of nommo - the power of the word. Likenesses and artifacts of Muhammad Ali, Angela Davis, Bob Marley, Bayard Rustin, Hattie McDaniels and many other respected orators occupy each available space on the walls and the ceiling. We sit down at black marble-top meeting table, and the discussion takes off.

Tupac: You know Nas and I had some beef, but I love the song he made with Lauryn Hill, "If I Ruled the World (Imagine That)." Although some of the content speaks to materialism, risky sexual behavior and druggin', there are other parts of the song that 
speak to freedom, agency, hope and self-determination. I especially like how he compares our people to black diamonds and pearls. I also like the line connecting to Marcus Garvey's Back to Africa Movement, "I'd open every cell in Attica and send 'em back to Africa" (Nas, 1996, Track 14).

The line that strikes me most, though, is how he describes his aspiration to exist in a multiracial world, “...the way to be, paradise...like relaxing... black, Latino and Anglo-Saxon" (Nas, 1996, Track 14). Nas' vision for the world is one that is grounded valuing cultural and racial differences, enjoying material possessions, travel and freedom to make choices without being judged.

\section{The OGs' Aspirations/Vision for Hip Hop Culture}

Tupac: OGs, I'd love to hear about your discussion around the vision for hip hop culture. My man Dyson who wrote the book about me said that hip hop culture is the most powerful force in the lives of many students, so we cannot ignore it (Dyson, 2001). With that being said, what should hip hop do? Where should it go next?

Ben: First, in alignment with scholars such as Marc Lamont Hill (2009), Kevin Powell (2001) and Michael Eric Dyson (2001), the group, in the main, ascribes to the position that hip hop culture is a powerful force that needs to be recognized as such. They also believe that hip hop culture should be viewed from an anthropological perspective, as it is lens through which groups of people make sense of the world. Some of also think that hip hop culture should be conscious-raising, enlightening and transformational. This statement is in alignment with the perspectives of hip hop cultural icons such as KRS -1 (as cited in Film for the Humanities and Sciences, 2005) and Wise Intellect (2009). Also, just as argued by hip hop culture critics Kephra Burns (as cited in Dyson, 2001) and 
Bishop T.D. Jakes ((as cited in Dyson, 2001), we also understand that, in its current state, there are many troubling aspects to hip hop. We are not excusing the culture from being responsible for its troubling messages and actions. Finally, we hope that the hip hop community will become more responsible and accountable for the impact it has on the world. There are a few examples of this that came up in our conversation.

\section{Hip hop culture should embrace its shortcomings and take on the}

responsibility of transforming communities. The OGs' position aligns with a sentiment stated by hip hop culture icon Chuck D, who argues that hip hop can "fuel the mind, as well as the body and soul" (as cited by Bragg et al, n.d.). In terms of hip hop being a powerful force, Ben says,

Hip hop should be a transformational force in the same way that gospel music was in the Civil Rights Movement. Music has always been a force in the black community. Hip hop has transformed black people and has kept us motivated. We have also been able to send disguised message through music. It can also transform our community. Hip hop is doing us a disservice (focus group interview, January 25, 2013)

Many of the OGs reflected on the Golden Age of hip hop culture (the 80s and early 90s) as they talked about hip hop culture's responsibility to "open up our heads" (George, Focus group interview, January 25, 2013). That is, hip hop has a responsibility to enlighten and transform the lives of disaffected youth, as it had done in the early years of the culture. As one OG, Lon, stated,

KRS-1 and PE, who I was raised on, taught us something. I'm not laying the responsibility on the shoulders of hip hop culture, but they should know they 
influence children. That's the way kids talk and assume a persona. They (leaders of hip hop culture) should be more conscious. The message is a lot different now (Focus group interview, January 25, 2013)

Several in the cipher agreed with the sentiment expressed by Lon, while at least one other person, LT, disagreed slightly. Ty concurred with Lon's sentiment, offering that powerful hip hop artists have shirked their responsibility. He argued that, "Through great power, comes responsibility" (Ty, Focus group interview, January 25, 2013). He also suggested that dissenting voices in the hip hop community need to say, "This is not what we're about. This doesn't represent our culture" (Ty, Focus group interview, January 25, 2013). Like another OG stated, Cam also argued that hip hop culture is doing blacks a disservice.

As discussed in the literature review, the sentiment that hip hop culture should be more radical and transformative in its orientation has been championed by scholars and hip hop culture icons alike. From the onset of hip hop culture's development, Afrika Bambaataa envisioned it to be one that would "reverse the savage destruction that was happening in the black community" (as cited in Toogood et al, 2012). Also, in a panel discussion sponsored by the Nation of Islam in 2009, cultural nationalist and hip hop emcee Wise Intellect suggests that hip hop has intentionally been placed on a course to promote troubling, self-injurious actions and mindsets. He suggests that the federal government is behind hip hop culture's post Golden Age downturn and points to several pieces of evidence to prove his point. "There are people in this society," Wise Intellect (2009) offers to the Nation of Islam's Saviors Day audience, “...who want to see us exactly where we are. You cannot let that point elude you." 
The capital in hip hop culture should be respected by academia. Being seen as legitimate, valued and worthy is an important value in hip hop communities - and particularly among black men (Majors and Billson, 1992). This legitimacy, also called street cred in hip hop circles, was referenced in the cypher. Ty argued that, because hip hop culture is such a significant force in communities, it should be recognized in the academic discipline of anthropology - the study of cultural behaviors and norms. In other words, hip hop culture should have street cred in academic circles. As Ty argued (Focus group interview, January 25, 2013), hip hop culture is still viewed as a trendy, johnny come lately phenomenon, but Ty pushes back on that perspective of hip hop culture, stating a point that aligns with researcher Dimitriadis' position that hip hop culture helps urban youth develop a sense of "self, place and history" (p. 78). Ty states,

Hip hop is a tool one uses to navigate through life. Through hip hop, people develop Sam language, make decisions, determine priorities and develop communication techniques. It's part of people's decision-making schema (Ty, Focus group interview, January 25, 2013).

\section{Critical Analysis of Hip Hop Culture}

Tupac: Okay, you have outlined your hip hop culture wish list for me. In terms of aspirations for the culture, you want hip hop culture to be empowering, responsible for its influence and respected as a legitimate cultural force. As you know, I'm very well read, and I understand CRT. From a critical perspective, can you give me an analysis of the current state of hip hop culture? I want make sure I have a good understanding so I can share it with Biggie. 
Ben: Yeah Pac, we have examined hip hop culture from a critical perspective. From our discussion we have three major takeaways. First, we contend that hip hop culture constricts the full humanity of black males by narrowly defining a normative archetype. Second, the troubling narrative has been broadcast, not just nationally, but globally as well. Finally, we OGs believe that hip hop culture, specifically the music aspect, is descriptive but not prescriptive. Several of these positions are supported by research as well.

Hip hop culture constricts the normative definition of black masculinity. One major challenge in hip hop culture today is that its mainstream images of black men are troubling, at least from the perspectives of the OGs in this conversation. Today, the OGs suggest, hip hop is dominated by images of black men as generally anti-social, violent, hypersexual, and pre-occupied with material possessions and excessive drug and alcohol use. In the article "Brotherly Love, Homosociality and Black Masculinity in Gangsta Rap Music," Matthew Oware takes a similar position, arguing that, "The cornerstones of gangsta music - hypermasculinity, misogyny, and homophobia - pervade the generation" (2011, p. 22).

Comparing black men in today's popular hip hop culture to the buffoonish, dimwitted black actors in the 1830s and 1840s minstrel shows, Don refers to the most popular narrative/caricature of black men as "Neo-Sambo" (Don, Focus group interview, January 25, 2013). He also says, "The breadth of hip hop culture has been limited by mainstream media. Hip hop is a caricature of authentic culture" (Focus group interview, January 25, 2013). Don does, however, concede that the presence of troubling narratives of black men in hip hop culture is nothing new. He specifically identifies Luke, a Miami- 
based emcee who gained popularity in the late 80 s and early 90 s with songs laced with highly sexualized and profane lyrics and videos crossing the lines of pornography. To support Don's claims, I offer the lyrics to one of Luke's group's most popular songs, "Move Something." The song contains lyrics such as “drop yo' draws and open yo’ legs up wide, bi\#ch" and, "bi\#ch bend over, let me do you like dogs do each other" (1989, Track 3).

Not only does hip hop culture help to forward the "black man as neo-Sambo" narrative, but, from a critical perspective, popular hip hop culture constricts the definition of black masculinity because it also marginalizes the black male as scholar archetype. As Lon (Focus group interview, January 25, 2013) one contends,

The bad part about hip hop is artists don't let you into their background. They don't tell you that this dude may have a college degree, may have a high school degree. What he was doing prior to hip hop. Why? Because it's not popular. Hip hop artists don't tell the whole truth. They don't give the light and the dark. Kanye West has college degrees, 2 Chainz has a master's degree. They don't talk about that because it's not popular.

Lon's position is supported/rationalized in the research. Patricia Hill (2006) provides a hypothesis around why educational attainment is de-emphasized among some black men in hip hop culture, as she writes, "Because so many African American men lack access to forms of political and economic power that are available to elite white men, the use of their bodies, physicality, and a form of masculine aggressiveness become more important" (p. 190). 
Ty also takes a similar position regarding the tension around normative definitions of black masculinity, sharing that, as a scholarly high school student, he found himself pushed to the margins, partly because of popular hip hop culture:

It was kinda unique growing up in East St. Louis. Growing up, I had no place in hip hop. When I was growing up, my peers and I lived somewhat of a protected life. Throughout school, my peers and I stayed together through high school. We were all in the same classes. They were trying to protect us from y'all (I'm just playing). Our teachers were actually selected. What it did was put a dividing line between myself and my brothers... When they look at you, and because you didn't have some of those same experiences, you were looked at as the establishment. You had no value (Focus group interview, January 25, 2013).

Marc Lamont Hill, in his research article entitled "Beats, Rhymes, and Classroom Life: Hip-Hop Pedagogy, and the Politics” (2009), discovered a similar phenomenon when attempting to use hip hop music and culture to inspire sociopolitical consciousness engage middle class black students. He found that hip hop music and culture did not resonate with black middle class students in a way that he had predicted. This underscores the point that black males are not a monolithic group and that hip hop culture may marginalize some cohorts of black males.

Also from a critical lens, Ty continues to speak about the limits of hip hop culture as it relates to black masculinity:

In terms of defining black male masculinity, we are talking about what it did, but we are not talking about what hip hop did not do. It did not teach us about being scholarly, being in love, or respecting women. If you are one of those guys who 
values other things besides mean mugging and being hard, you're not seen as being masculine. So what I had to do, in order to assert my masculinity, was to get jumped by six guys and do a little something afterwards just to prove that I was a man.

Having a different way that is outside of the hip hop culture's machismo was not masculine (Focus group interview, January 25, 2013).

At least according to the several OGs in this group, homosexuality is considered abnormal and is representative of everything that black masculinity is not. Pointing to hip hop emcee Lil Wayne publicly kissing a male colleague in the mouth, Easy E contracting AIDS, Snoop Dogg wearing manicured nails and the phenomenon of sagging pants, the OG research participants speak of a disdain for homosexuality. Lon and Sam both capture the general sentiments of several in the group. While Lon unapologetically expresses an anti-gay sentiment, Sam suggests that segments of the hip hop community may be becoming more accepting of black male homosexuality:

Lon: We don't embrace black male homosexuality. We have enough issues as black men already. To have that homosexuality demon...we got enough issues already. I don't want that to be another problem I gotta discuss with my kids. If you are gay, I would have to step away from you. You represent what I'm not (Focus group interview, January 25, 2013).

Sam: We are not ready for black male homosexuality. Frank Ocean is part of the hip hop community, and they have already accepted him. He is part of the black gay male revolution. Hip hop is the last frontier (Focus group interview, January 25, 2013). 
In the article, "'Out' in the Club: The Down Low, Hip-Hop, and the Architexture of Black Masculinity," Jeffrey McCune (2008) speaks to the challenges encountered by black males in hip hop culture - supporting some of the research participants' assertions that black gay males are considered cultural outliers. In McCune's article, because of the marginalization black gay males feel, they carve out spaces to "negotiate their masculine ideals and queer desire" (2008, p. 298). That is, gay black males find agency even in a world where they are marginalized by heterosexual black men. His essay explores the happenings at a hip hop club in Chicago called The Gate - a space where black gay males can engage with hip hop culture while asserting their sexuality in a nonjudgmental environment.

The OG research participants contend that hip hop culture narrowly defines black masculinity, and because primarily black men are imposing limiting cultural norms on other black men, the norms are self-oppressive. Putting black men into normative behavioral straitjackets denies black men the opportunity for self-actualization. This phenomenon of the oppressed turning inward on themselves is not new, as it is described in nuanced ways by Freire (1970) and Fanon (1967). Freire describes this phenomenon of internalized oppression as follows: "Chafing under the restrictions of this order, they manifest a type of horizontal violence, striking out their own comrades for the pettiest reasons. (1970, p. 62).

In addition to being self-oppressive, our conversations suggest that hip hop culture also sends a troubling narrative that informs the actions of many youth and also informs black folks' imaging all over the world. The group contends that, while hip hop 
culture promoted more balanced representations of black people in its Golden Era, the same is not true today.

From the perspective of a number of the OGs, the Golden Era of hip hop culture had a larger number of mainstream hip hop icons taking both antiracist, pro-black stances. Today, the OGs suggest, hip hop is dominated by images of black men as violent, misogynistic and excessive drug and alcohol-using. The statements below from Sam and LT illustrate the perspectives of the OGs most vividly:

Sam: When you say balance in life, I mean understanding the culture. We don't have balance anymore. When we grew up, we had NWA, but we had PE. We had DJ Quick, but we had Poor Righteous Teachers. One of the problems with hip hop is radio. They play the same 10 shits all day long. We used to search out hip hop. I don't know if kids are searching out hip hop. They are just digesting this crap. Even hip hop deejays are part of the problem, but they are getting paid thousands of dollars to play that crap. They are playing what's popular. A lot of them hate it more than we do, but it's what they get paid to do (Focus group interview, January 25, 2013).

LT: My point is that it was the balance that made me effective. I knew what was going on in the street. I saw people get beat up, stabbed and shot at, but I understood that if you don't achieve and stretch yourself to be what we know you can be, then there is gonna be a problem. Balance is important. That may have been a challenge with the kids in school now. The point is that hip hop should be understood, not followed (Focus group interview, January 25, 2013). 


\section{Hip hop culture transmits a troubling narrative that is mass consumed. In}

terms of the message hip hop culture is transmitting both nationally and across the globe, Lon is very critical. While others in the cypher spoke of hip hop's damaging dominant narrative, Lon captures the general argument in his comments. He says, The bad thing about hip hop is the messages we are sending about who we are. White people are mimicking our fucked up behavior. We have to take control of our ideas and what they are saying to our children....it carried the messages from the previous generations. It carried that message. It made sure that message got not just in the 'hood, but all across the world. I don't think that was good (Focus group interview, January 25, 2013).

In a recent interview posted on the Rap Basement website, hip hop cultural icon Scarface takes a position regarding mainstream culture that aligns with positions taken by Sam, Les and Lon in the previous paragraphs. Scarface, too, suggests that mainstream culture is narrowly defined, limiting and damaging to a generation of youth. He also articulates a conspiracy theory, similar to emcee Wise Intellect (cited in a previous paragraph). Scarface states,

There's no fucking way that you can tell me that it's not a conspiracy against the blacks in hip hop. You put out fucking records that make us look stupid. You make us look dumb. You brainwash a generation of hip hoppers with this fucking crud (as cited on www.rapbasement.com, 2013).

\section{Hip hop culture tells truth but does not necessary compel to action. In}

addition to creating a culture that can be self-oppressive and that transmits a troubling master narrative around black males, another critique of hip hop culture is that the culture 
tells stories and versions of "truth" but does not compel the generation towards liberatory action. Ty describes the phenomenon as "selling stories vs. telling stories" (Ty, Focus group interview, January 25, 2013). He argues:

If hip hop tells a certain truth from someone's perspective, the question is, "So now what?" It's like saying to me, "this is where we are, and this is what I went through, and this is why I went through that. I went through that because my daddy wasn't shit. I went through that because there were no people who look like me in the text I read. Now you got my attention, now you got me listening...and providing no solutions. You stop it at the juncture before saying, "this is what we can do" (Focus group interview, January 25, 2013).

Tupac: I must admit, that last point is pretty interesting, Ty. I say that because T.D. Jakes makes a similar point in Michael Eric Dyson's book on...well...me (as cited in Dyson, 2001). Interestingly, though, hip hop culture enthusiast and spoken word artist M.K. Asante disagrees with Ty, saying in the documentary How Hip-Hop Changed the World (cited in Bridger, 2011), “We've all grown up with hip hop. It's been telling us what to do for about three decades."

Anyway, to summarize, what I will report to my clique of OGs is that hip hop culture narrowly defines black male masculinity, sends troubling narratives about blackness across the globe, and tells stories but does not move people in the same way the Civil Rights Movement did - even though it has the potential to be transformative. You talked about how hip hop culture limits black masculinity, but I want to hear more about that. What is the archetype of black masculinity in hip hop culture? That is, specifically, what does it mean to be a black male in hip hop culture? Also, you keep 
referring to your group as OGs. What makes you an OG, and how is that definition different or like the more popular, narrow definitions of black manhood?

\section{Further Exploration of Hip Hop Culture and Masculinity: The OG}

Ben: From our discussion on these subjects, several major themes emerged. First, many of us have embraced many aspects of hip hop culture's narrow definition of manhood. Especially in our pre-teen and teen years, hip hop culture provided a manhood lesson for us. At the same time, the impact of other family and community members also shaped our definition and provided us with boundaries that helped to define us as black males. Different from our younger counterparts, we had a broader definition of what it means to be a black man. As a result, what an OG means to us may deviate from the dominant narratives around black male masculinity.

\section{Mainstream hip hop culture produces an archetype of manhood. Several of}

the OGs talked about hip hop culture provided a recipe for manhood. As Ben states that manhood in popular hip hop culture means,

I'm a thug. I'm a gangster is the hip hop definition of manhood. As a kid, hip hop made us think we needed to hustle and sell drugs. Hip hop had a great influence on defining manhood. It promoted materialism, violence and having hos (Focus group interview, January 25, 2013).

Don and Lon, who both have multiple female siblings, talk very specifically about men in hip hop culture serving in a big brother role, providing a role model for behavior. Don states,

I didn't have any brothers, so hip hop played a role in helping me develop my masculinity and reaffirm my identity as a male. It gave me some of those images I 
wanted...my dad taught me how to work hard and be responsible, but he couldn't teach me how to navigate the hood. As an athlete and a good kid, I had to make sure I wasn't a victim in the hood...I can use the images I hear in hip hop music and use those as I go into the John Deshields and John Robinsons, and I can feel comfortable...Hip hop said to us, 'In this neighborhood, this is what you gotta look like' (Focus group interview, January 25, 2013).

Lon's perspective is similar to Don's. He says, "I had four sisters, so hip hop did that for me. I saw these guys and I said, 'that's the dude I wanna be. Hip hop was that thing" (Focus group interview, January 25, 2013).

Ogbar (2007) provides a description of the persona that the research participants loosely described. He describes the archetype as real nigga. He makes the point that, Subsequent rappers like Tupac and Jay- $Z$ have celebrated the thug life while underscoring their real nigga status. Within this framework, rappers who extol ghettoized pathology (drug selling, gang banging, violence, pimping, etc.) affirm their realness. All other groups become peripheral and must conform to the standard established by this group. So lyrically and stylistically all artists place themselves within this contextual framework and to varying degrees appropriate [apparent] young African American males and markers (p. 43).

In summary, while hip hop culture helped to define some of the OGs' personas during their pre-teen and teen years, other influences helped to further define their masculinity. For the researchers, to be an OG is to be the embodiment of a fuller, broadened definition black masculinity. To be an OG is to be one archetype of black 
maleness. When the group discussed the definition of an OG, or an exemplar black man, a number of points emerged.

\section{OG status is not something easily attained and is granted, not self-}

appointed. While one criteria of membership is a connection to hip hop culture, being connected to, inspired by or informed by hip hop's cultural momentum does not necessarily equate to membership in the OG cohort. As LT states in the focus group interview, "I didn't recognize I was an OG until several young guys started calling me an OG” (Focus group interview, January 25, 2013).

\section{OG status is partially based on one's ability to build relationships and}

navigate in diverse environments. While there is sometimes internal conflict that black men feel as a result of having to navigate in multiple environments, an OG manages multiple sociocultural realities regularly and with ease. Several of the members spoke about being able to exist in two separate worlds of conflict. The first type of conflict they expressed is the street to suite conflict. That is, black men have to successfully navigate in urban, predominantly black and under-resourced communities and also maneuver seamlessly through the challenges of the white male-dominated, sometimes discriminatory realities of the dominant culture - the hegemonic definition of the real world. This position speaks to the duality that DuBois (1994) spoke most vividly about. As Ab states, he can communicate "to the street corners and to the Fortune 500 companies" (Focus group interview, January 25, 2013). Ben says he can "hang out in the South End and meet with a millionaire entrepreneur in the same day" (Focus group interview, January 25, 2013). Similarly, LT spoke of having the opportunity to golf on 
Pebble Beach, but he also reminisced about being a high school football player singing the most popular rap songs of the day on his way to football practice.

Second, an OG answers the challenge of successfully existing in multiple black sociocultural realities as well. For example, the social norms, communication styles and knowledge required for George to navigate the college experience at a historically black university may be different that those required to be comfortable in a hyper-competitive pickup basketball game in his low income housing project during his summer break. This multiple faces of blackness conflict, was highlighted in our discussion by several OGs. As an example, George, valedictorian of his all-black high school graduating class, spoke of his involvement in a gang during his high school years:

I existed in two worlds. My commission came out of the Greens in Chicago. Gangster Disciple was a forced issue for me... I was slated to be the next King...Tennessee told me real gangsters don't go to jail. It set my sights towards a different direction (Focus group interview, January 25, 2013).

\section{An OG is one who is responsible and prioritizes family and}

community. During our conversation, LT (Focus group interview, January 25, 2013)

alludes to these traits when he says, "I'm an OG because I handle my business. Raising a family and understanding that life is bigger than me and I have a responsibility for those who look like me. Ben adds to this notion by talking about how he has raised his daughter to strive for academic excellence and obtain full scholarships in both undergraduate and graduate schools.

\section{An OG has a wealth of experiences that can inform younger}

generation. As alluded to previously, the status of OG is not granted without a having 
specific skill sets and experiences. As Ab suggests, life teaches OGs lessons that younger Gs can learn from. An OG can be an effective counsel to younger counterparts. Ab states, Also, because of my life experiences, there aren't situations that young people are dealing with that I haven't dealt with. Whether it's women, money...I believe my life experiences have taught me enough where I can put the young Gs on the right path... and I got hos (Focus group interview, January 25, 2013).

One point that $\mathrm{Ab}$ makes illustrates one of the pain points evident in some sub-genres of hip hop culture. The marginalization of women - misogyny - is a pillar of gangsta rap culture, along with hypermasculinity and homophobia (Oware, 2010).

\section{Hip Hop Culture's Capital Summarized}

Tupac: Okay, I got it. The way you guys describe it, an OG is an earned designation that takes years to acquire. The people you consider OGs are responsible, family and community-oriented individuals who can thrive in multiple environments of challenge. One more things...well, two more things. First, what's good about hip hop culture... and what's up with you OGs using the word hos? It's the second time I've heard it.

Ben: First, I want to acknowledge that we took considerable time discussing critiques of hip hop culture, but we believe that a healthy, comprehensive critique of institutions is a crucial step to transforming the troubling aspects of them. We also know how important hip hop culture is to the lives of young black males. Next, I would like to talk to you about our discussion related to the strengths, or cultural capital threaded through hip hop culture. Similar to grass roots organizations such as the Black Panthers, Nation of Islam, Growth and Development (also known as the Black Gangster Disciples 
or GDs), and the Hip Hop Action Network, we lay out a platform of our beliefs with regard to hip hop culture.

\section{Hip hop culture provides a means for the marginalized to share their}

voices and their truths. Hip hop culture can be a sociopolitical narrator of the truths of people in disaffected communities. This point was not only made by the OGs, but Chuck D, a hip hop edutainer (educator/entertainer) and social activist, made a similar point when he compared hip hop's informational import to the CNN network (Ridenour and Steiner, 2000). Also, with regard to the role of the hip hop emcee, Banks compares the function of the emcee to the role of the African griot, saying, "Like these oral artists, the emcee also tells of his community's issues, its values, its ancestors, its heroes and heroines, its triumphs, and its struggles" (Banks, 2011, p. 240).

With regard to hip hop culture giving voice, a research participant stated, "NWA and Tupac were roving reporters in the hood. They were bringing attention to the lives and struggles of young people" (Don, Focus group interview, January 25, 2013). Even if the truths and knowledge contribute to troubling narratives, hip hop culture is the voice of numbers of disaffected youth, both nationally and internationally. In this research study, Sam talked more personally about how hip hop culture was helpful for him because it helped to express his angers and frustrations during his undergraduate years. Research study participant Don spoke more broadly, talking at length about hip hop culture being the international voice of social protest. He made several points in this regard:

They were bringing attention to the lives of struggling people. In so many ways it gives voice to young people. It's raw and undiluted. Even Trinidad [representative of Neo-Sambo archetype]. It's truth...somebody's truth...Hip hop is international 
now. Hip hop artists across the world have identified with the struggle of blacks and now use the medium to express their realities... While hip hop may have gotten more commercialized in the US, it still is reflective of the experiences of marginalized groups... Old school gangster music has the potential to bring attention to the lives of marginalized people (Don, Focus group interview, January 25, 2013).

\section{Hip hop culture is a counterstory of resistance, persistence and}

resiliency. According the $\mathrm{Ab}$, "The spirit of hip hop is a tale of going from nothing to something" (Focus group interview, January 25, 2013), and this theme is seconded throughout the Something from Nothing documentary, narrated by actor, emcee and entrepreneur Ice T (As cited in Toogood et al, 2012). Ab also suggested that hip hop says one can"... make it despite the odds" (Ab, Focus group interview, January 25, 2013). Several of the OG contingent cited Jay $\mathrm{Z}$ as the embodiment of this rose growing from the concrete ethos. When LT was asked if Jay $\mathrm{Z}$ had redefined the narrative around black males in the hip hop generation, he responded,

Yes, from my perspective, but even from my 14 year old son's perspective, he feels the same way when I ask him who does he look up to in the hip hop world. For him, Jay $\mathrm{Z}$ is the person he aspires to be if he were in that game (Focus group interview, January 25, 2013).

Ty (Focus group interview, January 25, 2013) added to LT's comments, saying: Another positive about Jay Z... When I listen to Jay Z speak and I watch him, I realize that a broader range of black males or African American males can say, "I can be like him, and it's ok." Whether you are middle class or in poverty...even if 
you can't relate to some of the stories he tells, there is enough about him where there is so much positivity to emulate. Wow, when he speaks, people listen. Wow, he knows how to put on a suit and dress in hip hop clothes. He is just that broad. He is more iconic than more people recognize.

With regard to Jay-Z, if book sales of Jay Z's biography/memoir Decoded are an indication, his rags to riches story does not only resonate with black males, but it is engaging to a broader, more mainstream audience as well. The book sold more than 50,000 copies and peaked in the top 20 on the USA Today's Best-Selling Book Lists (Rose, 2010).

\section{Hip hop culture demonstrates the genius of people of color. The OGs}

talked about the creativity of those who created the five elements that would eventually define hip hop culture. Sam talked specifically about how hip hop music is now respected as an original American genre of music. Don made the following statement regarding the genius embedded in hip hop culture:

The 5 essential elements of hip hop. This is some creative, deep shit. These cats started a whole new art form with a turntable and a couple of speakers. And created this creative rhythmic form of music...straight up freestyle. I mean, who can do that (Focus group interview, January 25, 2013)?

In addition to the conversation around the five elements of hip hop culture, the group also spoke about the genius embedded in hip hop culture that revolutionized the fashion industry.

Look at how hip hop changed the fashion industry. It single handedly took Tommy Hilfiger out of bankruptcy. Polo...look at the emergence of Sean John, 
Rock A Wear, and we revolutionized how jeans look. Timberland, FUBU, Adidas

It made FUBU a 2 million dollar company. It put Brown Shoe Company out of business (Don, Focus group interview, January 25, 2013).

4. Hip hop culture has the potential to be a transformational force. Hip

hop music, in particular is a part of a continuum of black music that has complemented and inspired social change movements. Hip hop culture has the potential to play a more active role in activating the critical consciousness of marginalized communities. Several of the OGs refer to the Golden Age of hip hop culture, where hip hop culture's icons promoted critical consciousness. As George stated, in the Golden Era, "hip hop enlightened a few folks" (Focus group interview, January 25, 2013). The group identified X Klan, KRS-1 and Public Enemy as representations of the critical consciousness that defined the Golden Age.

From a critical perspective, mainstream hip hop culture is providing troubling, limited caricatures of black masculinity. While the research participants concurred that hip hop culture has always contained images and promoted actions and worldviews that support troubling narratives about black men, they insist that the current, most dominant images of black men in hip hop culture are 21st century versions of stereotypereinforcing minstrel men and Sambos. The dominant archetype in hip hop culture is defined by hypersexuality, gangstaism and anti-intellectualism. Interestingly, while OGs critiqued the narrow definition of masculinity in hip hop culture, many of them admitted to being at least partially defined by limiting archetypes. Ab talked about "having hos" as an aspect of his manhood (Focus group interview, January 25, 2013) and both Don and Lon spoke of mimicking the gangsta persona in order to successfully navigate the hood. 


\section{The Schooling Experiences of the OGs}

Tupac: Now, I think I have a fuller, more balanced picture of hip hop culture, at least from the perspective of a group of college-educated OGs. Speaking of school, let's spend some time talking about school. First, I respect you brothers for sticking it out and graduating from college. You know, I was in the gifted program in school? The college thing wasn't for me, though. I dropped out of high school. I think I had what it took to graduate from college, but the streets got me.

What about you OGs. How was college?

College readiness. Ben: Great question, Pac. We broke our discussion of schooling into four parts. First, we discuss our college readiness. Next, we talk about our college experiences in the context of challenges, turning points and lessons learned. Then we talk about the five characteristics that would make an empowering educator for future OGs like us. Last, we do some further reflection and provide some recommendations to future OGs.

Ineffective preparation for academic rigor of college. During the conversation around schooling experiences, underpreparedness was a common theme. In fact, this is a common theme for black males across the country, as 35 percent of black male enrollees graduated within six years from selective and highly selected colleges in 1996, compared with 59 percent of white males, 46 percent of Hispanic men, 41 percent of American Indian males and 45 percent of the black women who entered the same year (Alexander, 2004). With specific regard to college preparedness, first, members of the cohort discussed how they had an inflated, false sense of readiness for the academic rigor of college; however, quickly after entering a college campus, reality settled in. Both Ben 
and Ty talk about the realization in similar terms. Ben says Focus group interview, January 25, 2013),

I was underprepared in the sense that I didn't have the academic muscle it took to succeed in college. At the same time, I had the confidence and nurturing (even if it was a false sense of confidence) to believe that I could persist through anything... and that was given to me by my educators... and my parents. Edward Swinney gave me the mantra of 'not the best, but the very best.' That's what drove me.

So, coming out of Lincoln, I thought I was the man, but I really wasn't shit. In terms of confidence and belief...I had this mindset that, 'I'm the man and can't nothing stop me.'

... calculus wasn't offered during my high school regular day, and I had to get to school an hour early if I wanted to take calculus. Well, I didn't have transportation to get to school early, so I didn't take calculus When I got to Mizzou, all of my colleagues had CAD and had physics and had calculus. When I went to the engineering school, I was struggling. I remember one of my professors told me, 'You are from East St. Louis. You should have changed your major.'

Ty's story of unreadiness is similar:

Like I said before, the gifted track we were on was a little different, so we were the shit...then I got to Mizzou and realized I wasn't shit. You have to embrace your failure, and make the most of it, but it's difficult. Then I ended up going to 
Harris-Stowe where my experience was just like my experience at Lincoln (Focus group interview, January 25, 2013).

Like Ty and Ben, Todd realized he had been academically shortchanged when he got to college. Admittedly, both Todd and Lon did not study much in K-12. Todd also contends that his K-12 schools "just pushed you through" (Focus group interview, January 25, 2013). Unlike the Ty and Ben, however, Todd talks about the limited number of career options provided to him in his pre-college experience. One of the downsides of his pre-college experience centers around his guidance counselors' inability or unwillingness to provide a more comprehensive exposure to career options (Todd, Focus group interview, January 25, 2013).

\section{Satisfactory preparation for academic rigor of college - not for social}

challenges. While Ty and Ben both suggest that they were underprepared for the academic rigor of college, George offers that he was well prepared for the rigors of college. It should be noted that all three of the aforementioned individuals attended the same high school and college. Also, all three received full academic scholarships. In response to the comments from Ty and Ben, George offers,

It's interesting that you all are saying this because I still have horror stories about the way my teachers pushed me. The thing I didn't leave with was a good perception or conception of what Mizzou was gonna be like.

Mr. Coleman would get in your mug and wouldn't let up. I was so prepared academically that I won national math state contests. I really thought I was prepared academically, but I really think it was people in my corner telling me, "No you gone do this." 
At Mizzou, I remember getting a 100 on the calc test and the instructor saying “[George], stand up.” I stood up, and he was like, 'That's a good joke.' When he realized it was actually me, he said, 'No black person has ever gotten a hundred on the math test.' I said, 'I guess it's a first time for everything, and you better believe it won't be the last.' Then he had his TA check over my tests with a fine toothed comb to make sure I would never get another 100.

I think it's teachers' obligation to make sure kids know what they are up against when they go to college. That's the only problem I have (Focus group interview, January 25, 2013).

Tupac: So it sounds like George, was prepared for the academic part of college, but he still highlighted a downside to his preparation, which is that he was not ready to be confronted by the sociocultural realities of college life, specifically life on a predominantly white, more selective college campus. Interestingly, though, both he and Ty transferred to a small historically black college with a less selective admissions profile and graduated with exemplary grades. For the most part during the conversation, all I heard were negatives about your pre-college education. All of you guys graduated from college, so you must have had some great teachers. Can you talk about what these teachers brought to the table?

The traits of excellent teachers. Ben: Absolutely, we talked extensively about positive factors in our pre-college experience that contributed to our graduating from college. Two contributing factors came up several times during our dialogue: confidence and pride. Our pre-college experiences gave several us the toughness and confidence to believe that we could move mountains. Also, even though some of us might not have had 
the best academic rigor, we were not dummies. After all, almost of all of us were smart enough to be selected for highly selective pre-collegiate internship programs and to also get college scholarships.

Several of the value orientations outlined in Dreamkeepers by researcher LadsonBillings are similar to the ones unearthed by the research participants. Specifically, Ladson-Billings (2004) suggests that effective teachers of black students must have a strong belief in the ability of each student, they must affirm students (especially students from diverse/historically marginalized backgrounds) and help those students connect to their multiple identities. Effective teachers of black students are artful in the ways that they mine students' strengths. The next section outlines some the OGs' perspectives around the characteristics and value orientations of an effective teacher, as embodied by teachers on both the K-12 and the higher education levels.

\section{Excellent teachers - affirm genius, expect excellence, show vulnerability and}

care, instill cultural pride. For the group of OGs, it appears that positive affirmations helped to build the confidence the OGs needed. As it relates to positive affirmations that build student confidence, Ben talks about principal Edward Swinney giving him the confidence to believe that he was a top-notch scholar. LT talks about how Mrs. Everett called his class "the number one honors class" (Focus group interview, January 25, 2013). Ty talks about how Mr. Dons "made us feel special and elevated" (Focus group interview, January 25, 2013). Last, in elementary school, Ms. McWorter referred to George as a "genius" (Focus group interview, January 25, 2013).

Pac: It seems to me that, although the academic successes in their pre-college years may not have prevented many of the challenges OGs would encounter as college 
students, their teachers gave them an opportunity to be successful and also gave them a sense of pride and positive self-concept. Can you give me some specific scenarios that speak to the impact of some of the OGs' pre-college educators?

Ben: Of course, Pac. As a researcher, exploring the characteristics of impactive educators is this one of the most important components of my research. I believe that current and future educators can learn a lot from old school educators. When I consider all of the stories the OGs tell about educators who profoundly impacted their life trajectories, three Sam characteristics emerge. First, the educators have extremely high expectations around academic achievement. Complementing the high expectations was a strong push and, for a few of the educators, their challenge was almost confrontational. Second, there was a humanity and vulnerability to the educators. Finally, several of the educators placed a premium value on black culture. They gave us pride in being black.

The three stories below provide examples of what you're looking for, Pac. First, there is George's scenario where he talks specifically about how his teachers affirmed his greatness and set high expectations.

Elementary school was Ms. McWorter. I had one boy who kept picking on me...Brian Washington and we fought every day. Ms. McWorter was like, "Why does a genius have to get his ass kicked every day?"

When I went to King Jr. High, Ms. Myrtle Harris was just phenomenal. When we took our first writing sample, she looked at me and called me Dr. [George] from then on. She told me, "You're gonna be a doctor one day." Then, I hit Lincoln. You had Ms. Farmer who wouldn't let up. You had Mr. Coleman and the Shaws. And especially my Spanish teacher, Ms. Jones. She 
didn't play. When I went to Mizzou, I was actually proud because, when I ran into Hispanic people and I could actually communicate with them in Spanish. Ms. Jones did not allow you to cut corners (Focus group interview, January 25, 2013). Second, we have Ty's recollection of Mr. Dons, a teacher who demonstrated high expectations but also showed vulnerability when tailoring his care to a unique students' needs:

Ronald Dons was remarkable to me because he showed you all sides of him. As a track coach, he would get in your ass. As a teacher, and as a male, his focus was on how articulate we had to be. You could not speak in incomplete sentences, without subject verb agreement, and when you read something in math... He was the only man who could wear the nut hugging shorts and not get talked about. $\mathrm{He}$ was that cool.

The way he taught us made us feel elevated and special because we were on the gifted track and we were all teachers' kids. But on the track team, there was John, who was burned pretty severely and had self-esteem issues. John smoked cigarettes and we knew that when Mr. Dons found out that he was gonna be mad and put him off the track team...but when we saw how he responded to John... he responded to his needs as a person, and we were able to sit back and watch him try to figure out what was missing in John's life and do what he needed to do to help john move forward. He taught me this whole thing about acceptance and being human. So it didn't matter who you were, you had value and he found it and used it to push you to the next level (Focus group interview, January 25, 2013). 
Last is Ben's description of an empowering educator:

The one who I tried to be most like was Edward Swinney at Davis Elementary School. He was my principal. I really tried as a principal to emulate him. He was like East St. Louis' MLK to me. I never dressed down...not that dressing is important, but it sends...but it sends a message. He understood the importance of celebrating black history and black culture. He was so ahead of the game that he wouldn't even let his boys go across the street to the store and eat all that sugar that the rest of us were eating. He was anti-sugar and pro-health. This was like in the 70s. He created this climate of achievement and this motto, 'Not the best, but the very best.' You know, they used to call Davis Davis University, and anybody from East St. Louis knows you got all of these other schools, then you have this perception (not that perception is the reality), that Davis is the best institution. So then, when I became a principal, I always wanted to be, not a principal, but an institution in the community, so when I came to Pine Lawn, I felt like, "Okay, this is my opportunity to be Mr. Swinney. Any of my students that have had me know, "Not the best... they know to chime in - the very best"' And so, that's what's what Mr. Swinney meant to me (Focus group interview, January 25, 2013).

Identity conflict and college experience. Pac: Wow, that's pretty heavy. I know our time is short, but I have just a few more questions. I want to learn more about your college experiences. Then, to finish out, I'd like for you to share some advice with the young and then also with OGs like myself, who are lifelong learners. Can you tell me about some of the challenges you guys had in college? 
Before that, though, I want to focus on getting a clearer understanding of the identity issues you guys had in high school.

Identity issues. Besides Ty speaking about how being sheltered from his nongifted peers in his K-12 experienced caused him dissonance between himself and his more worldly urban peers, two other OGs allude to identify conflict as well. Don states, “I didn’t know who I was. My identity has always been an issue” (Focus group interview, January 25, 2013). Don also says that his high school was a "celebration of whiteness" and that he didn't get steeped in black culture until he went to college (Focus group interview, January 25, 2013). Sam identifies a similar identity conflict. He suggests that, because he was one of two black students during most of his elementary and middle school years, he experienced identity confusion. Also, he says, "As a black man going through elementary, junior high and high school, I only had one black teacher. It was hard because I didn't have anyone that looked like me" (Sam, Focus group interview, January 25, 2013).

For Sam, his identity confusion was brought to a head when he was confronted by a black male teacher in an African American history in class in college. He recalls almost being brought to tears because of his lack of knowledge of the history of African and African-American people. For him, immersing himself in the study of black history and hip hop music helped him to resolve the conflict and anger he felt.

College experiences: Challenges, wake up calls and turning points. While the group shared a number of challenging college experiences, a number of the experiences center around racial conflict. Sam speaks of a law school experience: 
As bad as Mizzou was, for a number of different reasons - I had the frat at Mizzou so that helped out. Also some other good black people at Mizzou. But when I got to SLU, it was another level. It was like, 'We didn't want you niggas to have an undergrad degree, and we definitely don't want you to have this shit.'

So I had this professor...they worshipped this professor. I'd say he had to be at SLU a good 50, 60 years. He just recently passed at 90 something. Vincent Emmil, they just named a wing after him or something. Anyway, in my law school class, there were 8 of us. This was the biggest black class SLU ever had and this was 1996, so that wasn't that long ago. So the first semester you take Contracts. So we start the class, and he's talking to these white people like 'Yeah, 'I went to school with your father. I know your brother.'

Fast forward. At the end of the semester, they give you a problem, a legal problem to solve. It starts off like, 'Company ABC got sued by company DEF,' you know. So I sit down. This is my first law school exam, and the problem says, 'Company KKK..."

I'm looking...I'm thinking...I'm still on the clock because you only have an hour to solve this problem, right.... You got the whole semester in your brain, and the first thing you see is company KKK. It took me 15 minutes, you know, because of all of the letters in the alphabet, this motherfucker chooses the letters KKK ... and so it took me about 15 minutes because I had to tell myself, 'I been here before. I know what he is trying to do. I can't let him fuck me.' 
It did fuck with me. It affected my grade. I ended up getting a $\mathrm{C}$ or a $\mathrm{B}$, but it doesn't even matter. The other two black women in the class, we go to the dean. We are like, 'This is unacceptable. What are you gonna do to this professor?' Well, this dude just got his job. Do you think he's gonna challenge Emmet? Hell no. so he tell us basically, 'We're not gonna do anything. I'm sure it was a mistake.'

You knew they didn't want you to have a professional degree. I'd say on top of Mizzou, SLU was even worse, man (Focus group interview, January 25, 2013). Being confronted by racially prejudice actions took an emotional and academic toll on Don as well. In our conversation, he shares two incidents that reek of racial animosity. In the first scenario, also shares a story of white peers in his college dormitory spreading feces on his door and calling him "nigger boy" and "fuckin' monkey" (Don, Focus group interview, January 25, 2013). In frustration, he says, That freshman year, that did it for me. I was pissed off at white people for a long time. ...just having that feeling that you gotta deal with some extra bullshit. I can't just study for my political science final. I gotta come out and see fuckin' cowshit on my door? But just think about all the time we had to check white boys. I fought more at Mizzou than I did in Cahokia High...And you just got tired of that (Don, Focus group interview, January 25, 2013).

Last, Ben's experience with racism in college, though less direct and blatant than the confrontations experienced by Don and Sam, is no less concerning, as it speaks of internalized inferiority. As Ben (Focus group interview, January 25, 2013) states, 
The struggle for me was not to buy into the fact that I was actually not inferior to white people. It was this whole internal struggle that made me say, "Maybe they are smarter than me. Maybe they are naturally better than me. Maybe they are naturally smarter than me."

Because of the challenges I had academically. I got to the point where...it was because I had the buffering from E. St.... because after you start to get so many Fs, that shit starts to get in your head. I'm used to being the man... so it go to my psyche so much where I would study so much. So the rule in engineering was that you would study 3 hours for every credit hour you had. So typically I would study for about 45 hours a week. Well there are times where I would put 40 hours into studying for one class and because they got into psyche so bad I would go into a test and blank out. Because they actually did it to my psyche I understand how our people can buy into the inferiority thing because when you have an experience it starts to seep into your brain.

Pac: Thanks for sharing those stories with me. Despite the challenges, you guys showed resilience, as evidenced by the fact that you all graduated from college. So, you know I read a lot, right? There's this article by Smith, Yosso and Solorzano (2007) that explores a theme I hear coming out in your stories. They trio call the theme misandry, which they define as, "an exaggerated pathological aversion toward Black men created and reinforced in societal, institutional, and individual ideologies, practices, and behaviors" (Smith et al, 2007, p. 559). Their research, which is presented in the form of a counterstory, explores how misandric beliefs and actions impact black males' college experiences on a predominantly white college campus. Again, it is very similar to yours. I 
would say that getting feces spread across one's door, having to read Company KKK on a law school exam and having a professor not believe in a student's ability to score high on an exam are all examples of misandric actions.

Another point I want to make is that the identify conflict the OGs talk about makes it seem like DuBois' Souls of Black Folks was written just yesterday. He seems to describe your reality pretty well.

Okay, OGs, we should move to the next topic. The museum will close shortly. Based on your experiences, if you could time travel backwards, what advice would you give to your eighth grade self? Asked more broadly, what are some keys to a young black male reaching his fullest potential, despite challenging circumstances? Then, I want you guys to share with the older males in the hip hop generation. What books would you recommend to OGs like myself, lifelong learners?

Counsel based on schooling experience. Ben: In terms of the advice the OGs would give to our eight grade selves, the list below synthesizes the advice. It is straightforward and uncomplicated.

1. Be a leader and ignore urges to blindly follow trends because they are popular. Lead and others will follow. Most importantly, lead with integrity.

\section{Have a vision and set high, almost unreachable expectations. Hold high} expectations for yourself and for others. In fact, push beyond your own expectations. High expectations lead to maximizing one's fullest potential.

3. Take education seriously. Understand that education is the key to self-empowerment and expanded life opportunities

4. Make no excuses for yourself. Obstacles will come, but stay resilient and never quit. 
5. Welcome and confront challenge. Do not run from difficulties - annihilate them.

6. Read. Consume a variety of texts. Literacy is a key to empowerment.

Pac. Speaking of reading, we are now at the end of this conversation and this museum visit and I want to make sure I get a recommended book list from you before you leave. This conversation has helped me better understand the voice of a group of OGs from the Midwest, and I will make sure I share this conversation and the learnings with others who visit this museum... and the OGs who are with me on the other side. My conversations with visitors and my clique will center around three major themes you shared with me:

1. Aspirations for hip hop culture

2. A critical analysis of hip hop culture - exploring its role in creating both cultural capital and also supporting troubling narratives

3. Schooling experiences - especially focused on traits of empowering teachers, race-gender informed schooling experiences, identity and empowerment.

I think that's about it. Now, I'll take the book list.

Recommended readings. Ben. Absolutely. Check out the chart below. We will leave it with you. By the way, it has been a pleasure to meet you...

As I stood up to shake his hand, Tupac vaporized into thin air. The image that appeared to be Tupac was really the newest version of the 3D, artificially intelligent hologram of Tupac. The OGs were duped by technology. The image was remarkably lifelike. After the research participants and I gazed at each other in shock for a minute or so, we left the Cipher Room and slowly walked out of the Hip Hop Music of Culture and History. Before leaving, I left the book list. See the table below. 


\begin{tabular}{|c|c|c|}
\hline \multicolumn{3}{|c|}{$\begin{array}{l}\text { Table } 8 \\
\text { Books from the Literacy Lineage of the OGs }\end{array}$} \\
\hline Book (Date Published) & Author & $\begin{array}{l}\text { Rationale, Themes, General } \\
\text { Comments }\end{array}$ \\
\hline $\begin{array}{l}\text { Chains and Images of } \\
\text { Psychological Slavery (1984) }\end{array}$ & N. Akbar & $\begin{array}{l}\text { Describes the negative } \\
\text { impact of slavery on the } \\
\text { collective psyche of } \\
\text { Africans and African- } \\
\text { Americans }\end{array}$ \\
\hline $\begin{array}{l}\text { From "Superman” to Man } \\
\text { (1968) }\end{array}$ & J.A. Rogers & $\begin{array}{l}\text { - Debunks myths and } \\
\text { stereotypes about people of } \\
\text { color }\end{array}$ \\
\hline The Moors in Spain (1988) & $\begin{array}{l}\text { S. Lane-Poole and A. } \\
\text { Gilman }\end{array}$ & $\begin{array}{l}\text { - Says blacks are a resilient of } \\
\text { a people and can resist } \\
\text { oppression } \\
\text { - Underscores the importance } \\
\text { of establish one's self as a } \\
\text { leader }\end{array}$ \\
\hline Think and Grow Rich (1966) & N. Hill & $\begin{array}{ll}\text { - } & \text { Confront with failure } \\
\text { - } & \text { Set goals } \\
\text { - } & \text { Training your subconscious } \\
\text { - } & \text { Self-affirmation is } \\
\text { important } \\
\text { - } \\
\text { Self-esteem-building must } \\
\text { be internally driven }\end{array}$ \\
\hline $\begin{array}{l}\text { Teaching Reading to Black } \\
\text { Adolescent Males: Closing } \\
\text { the Achievement Gap (2005) }\end{array}$ & A. Tatum & $\begin{array}{l}\text { - Literacy of black boys is a } \\
\text { collective responsibility } \\
\text { - We must pay attention to } \\
\text { the need or suffer the } \\
\text { consequences }\end{array}$ \\
\hline $\begin{array}{l}\text { Jesus and the Disinherited } \\
\text { (1949) }\end{array}$ & H. Thurman & $\begin{array}{l}\text { - Activism is a lifelong walk } \\
\text { and evidence of one's } \\
\text { philosophy } \\
\text { - Education brings about a } \\
\text { divine responsibility to } \\
\text { serve }\end{array}$ \\
\hline $\begin{array}{l}\text { Before the Mayflower: A } \\
\text { History of Black America } \\
\text { (1969) }\end{array}$ & L. Bennett & $\begin{array}{l}\text { Comprehensive survey of a } \\
\text { broad time span of black } \\
\text { history } \\
\text { - Seminal piece, as the story } \\
\text { is black people is told by a } \\
\text { black scholar }\end{array}$ \\
\hline Souls of Black Folk (1994) & W.E.B. DuBois & $\begin{array}{l}\text { Describes black males' } \\
\text { inner conflict and turmoil }\end{array}$ \\
\hline
\end{tabular}




\begin{tabular}{|c|c|c|}
\hline & & $\begin{array}{l}\text { Had to read as part of } \\
\text { college experience }\end{array}$ \\
\hline $\begin{array}{l}\text { Black Awakening in } \\
\text { Capitalist America (1969) }\end{array}$ & R. L. Allen & $\begin{array}{l}\text { Laid out conspiracy theory } \\
\text { around black disaffected } \\
\text { being purposefully diverted } \\
\text { from seeking self- } \\
\text { determination through the } \\
\text { Civil Rights and Black } \\
\text { Power movements to } \\
\text { seeking personal financial } \\
\text { success. } \\
\text { - Changed career path }\end{array}$ \\
\hline Cool Pose (1992) & $\begin{array}{l}\text { R. Majors and J.M. } \\
\text { Billson }\end{array}$ & $\begin{array}{l}\text { Describes the persona of } \\
\text { black men in the hip hop } \\
\text { generation - and } \\
\text { generations before. } \\
\text { Describes a hypermasculine } \\
\text { pose that limits black } \\
\text { masculinity }\end{array}$ \\
\hline $\begin{array}{l}\text { Pedagogy of the Oppressed } \\
\text { (1993), to be followed } \\
\text { immediately by The Pruitt- } \\
\text { Igoe Myth (2012) }\end{array}$ & $\begin{array}{l}\text { P. Freire } \\
\text { C. Freidrichs et al }\end{array}$ & $\begin{array}{l}\text { Pruitt Igoe helps us to } \\
\text { understand the engineering } \\
\text { of the separation of black } \\
\text { families } \\
\text { - Noted writer in STL talked } \\
\text { about the conflict his } \\
\text { mother had as a moral } \\
\text { woman being righteously } \\
\text { dishonest } \\
\text { Can help students put life in } \\
\text { context - then, now, next }\end{array}$ \\
\hline $\begin{array}{l}\text { Autobiography of Malcolm X } \\
\text { (1992) }\end{array}$ & $\begin{array}{l}\text { M. X } \\
\text { A. Haley }\end{array}$ & $\begin{array}{l}\text { - Showed how a black man } \\
\text { could transform and impact } \\
\text { the world } \\
\text { - Popular archetype of } \\
\text { masculinity }\end{array}$ \\
\hline $\begin{array}{l}\text { Miseducation of the Negro } \\
\text { (1990) }\end{array}$ & C.G. Donson & $\begin{array}{l}\text { - Sociocultural analysis is } \\
\text { still relevant today, even } \\
\text { though it was written many } \\
\text { years ago. }\end{array}$ \\
\hline
\end{tabular}

\section{CONCLUSION}

Instead of discussing emergent themes in the more traditional research analysis

formats, this research discusses them in a fictional conversation between the research 
participants and the late Tupac Shakur - in the fictional Museum of Hip Hop Culture. Led by Tupac, the research participants take a tour through the Museum of Hip Hop Culture as first-hand observers. In a research study that also explored the higher education schooling experiences of black males, Smith et al (2007) explored ways that misandric beliefs and actions impacted the college environment for a focus group of black males on a predominantly-white campus. This research, through a CRT lens, explored the intersection of hip hop culture, black males and their schooling experiences. Our findings center around three major themes that have been embedded in the counterstory:

1. The OGs' aspirations for hip hop culture

2. A critical analysis of hip hop culture - exploring its role in creating both cultural capital and also supporting troubling narratives The OGs' schooling experiences - especially focused on traits of empowering teachers, race-gender informed schooling experiences, identity and empowerment 


\section{CHAPTER 5}

\section{DISCUSSION}

This chapter begins with a summary of the study. Following the summary of the study, this chapter further explores the connections between the research findings and major themes outlined in the literature review. Next, this chapter discusses the possible implications of the research and makes recommendations for future study/research, within the context of existing literature and research. Next, limitations of the study are discussed. Finally, this chapter offers a conclusion which is grounded in a conversation around the four guiding research questions.

\section{Summary of the Study}

Using a critical lens, the overarching purpose of this narrative study is to contribute to the discussion around education reform and leadership by privileging the voices, schooling experiences and cultural capital of a marginalized group: the OGs of the hip hop generation. More specifically, the purpose of this study was threefold. First, this study aimed to unpack the schooling experiences of a cohort of black men who selfidentify as being part of the hip hop generation. This study also explored the ways that the participants align with and/or challenge dominant narratives around black men in the hip hop generation. Third, this research explored the ways that hip hop culture has influence, inspired, informed and inhibited the research study participants. After exploring the existing literature around the intersections of black male narratives/discourses, black males' schooling experiences and hip hop culture, the study outlined the findings of the focus group engagement. Findings were highlighted using the 
counterstory methodology. While Chapter 4 explored the connections between the research findings and the literature/research in a broader sense, the next section of Chapter 5 will specifically connect those research findings to the existing literature and research around the intersections of three broad themes: Critical Race Theory, hip hop culture and schooling.

\section{Further Connections: The Literature and the Findings}

Critical Race Theory (CRT) has five broad components: 1) The centrality of race/racism, 2) challenge to dominant ideology, white privilege and color blindness, 3) commitment to social justice, 4) privileging the import of cultural capital and lived experiences and 5) interdisciplinary scholarship (Yosso, 2005). This section will explore the extent to which the research findings align with components of the CRT framework, including the counterstory, which is a form of cultural capital.

First, in terms of findings that speak to the centrality of race, a sect of participants, when discussing their college experiences, spoke specifically about experiencing aggressions and microaggressions that they attribute to race. Don (Focus group interview, January 25, 2013) shared that feces was spread on his college room door, allegedly by white dorm residents, and Sam (Focus group interview, January 25, 2013) discussed a scenario in which his law school professor used the name of a white supremacist organization in a final exam item. Along with these examples of racial prejudice toward blacks, the research findings speak to some the troubling impacts and outcomes of racism: identity conflict, internalized oppression, feelings of no agency and hegemonic narratives. 
Like DuBois spoke of in Souls, the participants spoke of the identity conflict he described as a "world which yields him no true self-consciousness" (p.2). For some participants, the identity conflict was due to the lack of male role models in predominantly white environments (Don, Sam, Focus group interview, January 25, 2013). For another participant, the alienation and identity conflict came about because he felt that his scholarship and life experiences put him on the margins of hip hop culture (Ty, Focus group interview, January 25, 2013). For another it was the conflict of managing both gang life and high academic expectations (George, Focus group interview, January 25, 2013).

Also from a CRT lens, an outcome of racial oppression is an inferiority complex among the oppressed people. As Fanon (1967) states, the phenomenon of internalized inferiority is common among "...every colonized people - in other words, every people in whose soul an inferiority complex has been created by the death and burial of its local cultural originality...” (p. 18). Ben spoke at length about how his failure in his college courses caused him to struggle with feelings of inferiority because of his race (Focus group interview, January 25, 2013).

As mentioned previously in the research, internalized oppression is an outgrowth of racism as well (Freire, 1970). From the CRT perspective, racism's force causes internalized oppression, and cultural deficit models do not explain racial asymmetries. Also, from a CRT perspective, those who exhibit internally oppressive actions and mindsets may impede the agency of self and others in one's racial group. During the focus group, there were examples where sentiments aligned with dominant, troubling narratives around hip hop culture and black males. Sentiments of homophobia, misogyny 
and hypermasculinity, were present among the participants. Two exemplars adequately illustrate the sentiments. During the focus group, Lon referred to gay males and "demons" (Focus group interview, January 25, 2013), and Don talked about look in the mirror to develop the hypermasculine pose commonly assumed by tough guys in his community (Focus group interview, January, 2013).

As another example of using a CRT lens to further explore internalized oppression's role in defining black masculinity, I refer to the Introduction of this research study. In it, I described one of my personal archetypes of masculinity growing up, Louis Farrakhan, and highlighted his fair complexion and wavy hair. From a CRT perspective, the fact that I chose to highlight may speak to Fanon's concept of epidermalization (or deeply internalizing inferiority) and Freire's notion of the oppressed using the oppressor's yardstick. During the conversation with the OGs, there was much more animus towards whiteness than an expressed desire to emulate or embrace whiteness. That is, the notion that black men want to be white men, as argued by Fanon (1970), was not supported in the focus group, but it could be implicit in my description of Louis Farrakhan.

Explored in the previous section, the import of racism is just one aspect of CRT that is connected to the research study. In addition, this research aligns with the CRT orientation because it challenges dominant ideologies and white privilege. First, with regard to hip hop culture, both the literature review and the research participants submit that hip hop culture is an exemplar of the genius of poor people of color. This assertion lies in contrast to the dominant discourse around black males and hip hop culture. Stated differently, nationwide achievement data, prison population statistics, and mainstream 
media provide a narrative of black males in hip hop culture that does not frequently highlight evidences of black male achievement. As alluded to by Don, hip hop culture, created by poor black and brown youth, provides a multilayered evidence of the undervalued genius of the disenfranchised in the culture.

Also, as it relates to challenging dominant narratives, this research privileges the knowledges and narratives of natives of historically low income communities. Specifically, this research privileges the narratives of natives of E. St. Louis, Illinois, an under resourced, low income community. It challenges narratives promoted by the Savage Inequalities author and Saturday Night Live executives. As one research participant contended, one of the current archetypes of black masculinity in hip hop culture is the neo-Sambo (Don, Focus group interview, January 25, 2013). The fact that the research participants all have college degrees challenges the anti-intellectual black male narrative.

Another component of the CRT framework is the social justice orientation. From some of the research participants' perspectives, the social justice orientation is missing from hip hop culture. When Bambaataa laid the ontological foundation for hip hop culture, he sought “...power, education in truth, freedom, justice, equality, work for the people, and the up-liftment of the people." He also said, "There are so many of the Human race who are blind, deaf, and dumb to the knowledge of self and others, and we feel the ones who know should teach" (Universal Zulu Nation, 2013). The research participants spoke of the impact more critically conscious hip hop artists had on raising their sense of self awareness and "enlightening a few folks" (George, Focus group interview, January, 2013). 
Finally, privileging cultural capital and knowledges is a component of the CRT framework that is evident is this study. The research participants spoke of the cultural capital embedded within hip hop culture, critiqued hip hop culture, defined an archetype of black masculinity, outlined characteristics of transformative teachers, provided a list of recommended readings, provided a set of best practices for young males. The cultural capital and knowledges are shared in the form of research findings, using the counterstorytelling method.

The research literature and the research findings both support the position that hip hop culture itself is a counterstory, as defined from the CRT lens. A counterstory upends dominant notions around marginalized racial groups and is a liberatory effort toward self and group agency. In the literature, the ways that hip hop culture has embraced, encouraged and initiated racial solidarity and social justice efforts was discussed. From Bambaataa to Chuck D, and from the Zulu Nation to the Hip Hop Summit Action Network, hip hop culture has been grounded in principles of social justice and has galvanized, motivated and strengthened at times. Like counterstories do, hip hop culture provides a voice that has challenged dominant knowledges, especially through politically -consciousness tracks like NWA's “F \&^k the Police”. Also, like counterstories do, hip hop culture creates new realities and possibilities. Caz, the hip hop godfather states, "Hip hop didn't create anything, but it recreated everything" (as cited in Toogood et al, 2012).

The research findings also support the notion tha that hip hop culture represents a counterstory. Several of the OGs talked about the Golden Age of hip hop culture providing critical perspectives, strength and motivation during challenging times. Also, 
the bonds that the researchers have with each other are supported by memories where hip hop culture plays a major role. For the participants, Jay $\mathrm{Z}$ was the manifestation of hip hop's counterstory. A self-described, ex drug dealer, womanizer, Jay Z has emerged from a crime ridden community to gain the respect of hip hop heads and the head of the United States of America. For the OGs, Jay Z is the counterstory of hip hop.

\section{Implications of the Research Study}

Before presenting the implications of the research study, it is important to note that this research is not designed to be racially essentialist or deterministic in nature. That is, this study is not to imply that black males in the hip hop culture are monolithic. Indeed, we do not all have the same beliefs, mindsets, opinions and experiences. We do recognize that a variety of factors play into worldviews, experiences and behaviors. At the same time, we recognize that hip hop culture has been a constant in the lives of urban youth for over 30 years.

Also, it should be noted that the extensive literature review process did not yield any studies that implicitly or explicitly suggested that successful execution of culturally responsive, antiracist actions are contingent upon racial membership. Stated differently, an educator's racial identity does not necessarily contribute to or detract from an educator's ability to implement culturally responsive pedagogies. While this study supports the assertion that one's race might influence both school experiences and educational approaches, it rejects the notion that race determines efficacy.

The possible implications of this study are separated into three broad categories. One implication is that this research contributes to the scholarship around culturally responsive pedagogies. It does this by synthesizing a set of frameworks that promote 
empowering educational outcomes that challenge the status quo. These frameworks have both transferability and adaptability. That is, these set of best practices can be used in a number of educational environments, and they also can be adapted across lines of difference and for a variety of educational outcomes. Along with synthesizing a set of best practices, the black males in this research study identify a set of teacher characteristics that closely align with characteristics of effective teachers - as outlined by Gloria Ladson-Billings and others.

Another implication of this study is that it supports and contributes to the research around the import of literacy as an empowerment tool for black males. Specifically, this qualitative study supports the work of literacy experts Alfred Tatum and William Brozo, who provide strategies to engage males through text. This research study addresses four major themes discussed by Tatum and Brazo: enabling texts, building resilience through text, literacy lineages and archetypes of masculinity.

A final implication of this research study is that it expands the conversation around both the strengths and problematic elements of hip hop culture. Hip hop culture is one of the most impactful cultural forces of the last 30 years, and this research - through the creation of a counterstory - teases out some of the cultural capital embedded in hip hop culture as well. As researchers contend, counterstories can "jar dysconscious racism" (Ladson-Billings \& Tate, 1995, p. 58). While parts of the research findings challenge troubling dominant narratives around black males and the hip hop generation, there are other findings that suggest that the participants contribute to some of the troubling narratives. 


\section{Research Adds to Knowledges around Responsive and Antiracist Pedagogies}

One of the implications of this study is that it synthesizes a value orientation and set of beliefs that that define culturally-responsive, empowering educators. Also, explicitly connecting to students embracing hip hop culture, the research also outlines the characteristics of an educator who represents, or who helps students who embrace hip hop culture move towards critical consciousness - through the prism of race, class and power (Irizarry, 2009). In addition, researcher Geneva Gay (2002) offers five nonnegotiables for creating a culturally responsive learning environment. Also, in connecting critical educational pedagogy with hip hop culture, researchers such as Alim Williams (2009) develop the Critical Hip Hop Pedagogy framework. Together or separately, these value orientations, educator profiles and non-negotiables are designed to lead to the goal of empowering education for students of color.

The focus group findings support the research around culturally responsive education. Just as Ladson- Billings' research yielded a synthesis of characteristics of effective teachers of black students that she summarized in Dreamkeepers, this research outlines a set of characteristics very similar to the ones articulated in Ladson-Billings' work. Not only do these research participants articulate a set of characteristics that define exemplary teachers of black males, but they also provide a set of keys to success for middle school age black males. Like the educators in Ladson-Billings' research, the educators the OGs discussed had extremely high expectations around academic achievement. In addition, they built confidence in students by stretching them both academically, socially and emotionally. At the same time, the educators showed an unexpected vulnerability and sensitivity to students on the margins. Finally, a number of 
the teachers explicitly or implicitly expressed the importance of learning about the experiences of blacks in the United States and abroad. Several of the educators mentioned helped to instill a sense of black pride in the researchers.

In Crossing Over to Canan: The Journey of New Teachers in Diverse Classroom (2001), Ladson-Billings moves in a more radical direction, proposing that culturally responsive teachers need to help students develop a sociopolitical consciousness. Three of the research participants spoke of a Sundiata, a college professor, who challenged them and elevated their sociopolitical consciousness. Don talked about how the professor challenged his academic apathy and subsequently inspired him to become a lifelong reader of conscious texts. (Focus group interview, January, 2013).

The concept of teacher representin' was also supported in the research findings as well. Ben highlighted the book, Black Awakening in Capitalist America as one that transformed his consciousness. Professor Sundiata's recommendation of the book was his way of challenging Ben to fight against the status quo of creating a career in corporate America. Instead, this book inspired Ben to choose a career in a community service profession.

While the research highlighted above explored value orientations, educator profiles and educator non-negotiables that may inform the work of aspiring and present educational practitioners and researchers, it lacks the succinctness and coherence of the antiracist educational actions first outlined in Table 4 of this study. For review, they are listed again on the next page. 


\begin{tabular}{|c|c|c|}
\hline \multicolumn{3}{|c|}{$\begin{array}{l}\text { Table } 9 \\
\text { Antiracist Actions in Three Areas of Schooling }\end{array}$} \\
\hline $\begin{array}{l}\text { School/Community and } \\
\text { Interpersonal Relationships }\end{array}$ & \begin{tabular}{|l} 
Curriculum \\
\end{tabular} & Institutional Change \\
\hline $\begin{array}{l}\text { 1. Communicating high } \\
\text { expectations to students } \\
\text { of color } \\
\text { 2. Educating white } \\
\text { colleagues and parents } \\
\text { 3. Further educating self } \\
\text { 4. Outreach to parents of } \\
\text { color } \\
\text { 5. Advocating for students } \\
\text { of color }\end{array}$ & $\begin{array}{ll}\text { 1. } & \text { Including multicultural } \\
\text { literature and themes } \\
\text { 2. } & \text { Racism and as } \\
\text { curriculum topic } \\
\text { 3. Teaching about racial- } \\
\text { identity development } \\
\text { 4. Teaching about } \\
\text { stereotypes } \\
\text { 5. Including perspectives } \\
\text { of people of color in } \\
\text { social studies }\end{array}$ & $\begin{array}{l}\text { 1. Question assessments } \\
\text { for special education } \\
\text { 2. Challenging racist } \\
\text { behaviors among } \\
\text { current or prospective } \\
\text { staff } \\
\text { 3. Changing grouping or } \\
\text { testing practices } \\
\text { 4. Providing support } \\
\text { programs for students of } \\
\text { color }\end{array}$ \\
\hline
\end{tabular}

This research suggests a set of best practices and frameworks that are culturallyresponsive and radical-leaning practices, and can be used adapted for use in a variety of educational settings. The antiracist actions listed in the table above, segmented into three major areas, may drive mindsets, behaviors, and actions in a broad range of academic settings (i.e., P-12, higher education, after school activities, etc.). The actions listed above have both adaptability and transferability across lines of difference. Paulo Freire's problem-posing framework, representin' and the various culturally-relevant mindsets, belief systems, and orientations all have adaptability and transferability as well. Also, the frameworks all address issues of power, privilege and identity in a way prioritizes the importance of dismantling racist structures and provides means for students of color to self-actualize. 
While the antiracist and critically responsive frameworks are general and adaptable, Critical Hip Hop Pedagogy (CHHP) is a more specific framework, as it promotes the infusion of hip hop culture and schooling in ways that explicitly challenge the status quo. It should be noted that $\mathrm{CCHP}$ is a radical sociocultural framework that essentially adds hip hop culture's socioculture to the Freire problem-posing framework.

\section{Research Contributes to Conversations Around Black Males and Literacy.}

Another implication of this research is that it contributes to the research around the importance of literacy instruction, Alfred Tatum (2009) suggests,

The long tradition of failing to provide effective reading instruction for students who continue to underperform...is deeply rooted in cultural, economic, linguistic, historical, sociological, and psychological factors that many well-meaning teachers are not prepared to address...As a result, many of the nation's children who can benefit from their teachers having a more comprehensive understanding of their literacy needs remain vulnerable to failure...thus increasing their chances of unfavorable life outcomes (pp. 2-3).

In alignment with Tatum's position, the OGs explicitly and implicitly suggested literacy as a key to empowerment and self-actualization. Ty even cited the book by Tatum, Teaching Reading to Adolescent Boys: Closing the Gap as a book that he would recommend to others. Other participants in the focus group also spoke very passionately about texts that empowered, informed, motivated and explained them. That is, the group talked about texts that were enabling. The OGs' conversations specific to the impact of literacy support and, perhaps, add to the work of literacy experts such as Drs. Alfred Tatum and William Brozo. 
As Alfred Tatum states in his book, Reading for their Life: (Re)Building the Textual Lineages of African American Adolescent Males (2009, p. 55),

We need to (re)connect African American adolescent males with texts in order to begin shaping a positive life trajectory for them. Unless powerful texts anchor literacy reform-texts that are models of rich language-these young men will continue to be underserved in schools.

In the Tatum text to which Ty refers (Teaching Literacy to Adolescent Black Boys), Alfred Tatum (2005) outlines several keys to changing black boys' life trajectories through literacy. He contends that "literacy development can also be powerful for black males when it acknowledge their current existence while not allowing them to become limited by that experience" (p. 48). Hip hop culture, as argued by the research participants, is valuable because of its reflectivity - it acknowledge and holds a mirror up to the reality of many people's existence. Making the connection between literacy and hip hop culture, several researchers have used hip hop song lyrics as text in an effort to engage black boys (Low, 2010; Rodriguez, 2009; Stovall, 2006). This research around the intersections of hip hop culture, black males and schooling is additive because to previous research because it, too, connects hip hop culture and literacy.

To use literacy as a tool for empowering black males, Alfred Tatum argues that educators must 1) use enabling texts and 2) help students build literacy lineages (Tatum, 2009). In a number of ways, this research with a subsection of hip hop culture's OGs supports Tatum's work, and, perhaps adds to it. Also, the research also dovetails with the work of William Brozo, who talks very specifically about ways to use models of masculinity, which he calls archetypes, to connect black boys with literacy. 
The import of enabling texts. As Alfred Tatum states, in the article "Enabling Texts: Texts that Matter (n.d., p. 2)

These students need exposure to enabling texts. An enabling text is one that moves beyond a sole cognitive focus-such as skill and strategy development-to include an academic, cultural, emotional and social focus that moves students closer to examining issues they find relevant to their lives.

Also, according to Tatum, enabling texts help black males "define self, become resilient, engage others and build capacity" (2009, p.3). When the OGs spoke of texts that resonated with them, several of the participants identified texts that would be considered enabling texts. For example, Don recommended the text Jesus and the Inherited. The major messages in this book are 1) visible activism toward social justice outcomes must be part of one's spiritual foundation and 2) those who are formally educated have an obligation to improve the lives of others (engage others, build capacity). Sam spoke about how Before the Mayflower provided him with a connection to the historical journey of black people (define self). Other recommended texts, such as Chains of Psychological Slavery and From "Superman" to Man, are written with the purpose of helping blacks gain a stronger sense of the 1) the impact of racism on blacks' psyche and behavior and 2) the historical evidence of the genius of the black man. The book Ab recommended, Think and Grow Rich, helped him learn how do manage failure, set goals, think positively, and eliminate negativity in one's daily life (become resilient, build capacity, define self).

Building resilience in black males through literacy. When discussing their schooling experiences, several of the OGs talked about overcoming formidable 
challenges. The challenges typically centered around identity conflict, lack of academic preparation and blatant acts of racial prejudice. All of the OGs in the study showed a level of resiliency, and at least three spoke specifically about being confronted by a racist act. Don, for example, was able to graduate from college in four years, despite being confronted with situations like having feces on his door. Ben was able to graduate with an engineering degree, despite internalized notions of inferiority and despite being woefully underprepared for the rigor of the engineering curriculum. Sam was able to complete his Contracts course in law school, despite being taken aback by the Company KKK scenario. Lon, who served time in jail, admitted to his lack of reading skills but still was able to graduate from college and is currently pursuing a doctorate in education.

Resilience, according to Alfred Tatum's research, is something that educators can integrate into literacy instruction as a way to empower black boys. In the article "Reading and Resilience,” Tatum argues, “...educators can help students develop resilient personal characteristics or provide strategies that help them adjust to their lack of skills (2009, p3)." One way is to "build a relationship between students' background knowledge and experiences and the content included in the text selection (Tatum, 2009, p. 5). Practices such as these engage and empower black males and help to build literacy lineages.

Literacy lineages. A literacy lineage, as described by Alfred Tatum, is a portfolio of texts that have played a role, first, in deepening a black male's interest in reading. Second, a text that is a part of a black male's literacy lineage often inspires and transforms him. Tatum identifies The Autobiography of Malcolm X, as a book in his literacy lineage. The story of a black man who transformed his life from an ex-con and street hustler to a transformational leader who sat at the helm of both the Nation of Islam 
and the Organization of Afro American Unity, Malcolm X's autobiography was a book Sam said he would recommend to high schoolers. In other words, Sam thought the book should be a part of a black male high schooler's literacy lineage. Others recommended books such as Pedagogy of the Oppressed, Miseducation of the Negro, The Souls of Black Folks, and The Moors in Spain as books black males should make part of their literacy lineage. The research participants spoke passionately about how the aforementioned texts impacted their critical consciousness.

Archetypes of masculinity. While one key to deeply engaging black males in the schooling process is providing enabling texts that help the students (a) define themselves, (b) build self-efficacy, (c) empower others and (d) build capacity (Tatum, 2009), there is another related key. Brozo (2002) suggests that many enabling texts have archetypes of masculinity that resonate with the male experience/general interests and facilitate a greater connection between boys and schooling. In Table 10 is a description of the archetypes Brozo (2002) identifies as central to connecting boys to texts.

\section{Table 10}

Archetypes that Connect Boys to Literacy (Brozo, 2002)

\begin{tabular}{|l|l|}
\hline Archetype of Masculinity & Description \\
\hline Healer & Capable of bringing wholeness to those who are suffering \\
\hline King & Embodies greatness and creates greatness in others \\
\hline Lover & Caring, compassionate and sensitive \\
\hline Magician & Clever, intuitive \\
\hline Patriarch & Father and mentor \\
\hline Pilgrim & Filled with hope and faith \\
\hline Prophet & Driven by a cause, ethically unwavering \\
\hline Trickster & Satirical and fun \\
\hline Warrior & Brave, moral, honorable \\
\hline Wildman & Lusty, unpredictable \\
\hline
\end{tabular}


In this study, we see evidence of some of the above archetypes of masculinity resonating with the research participants. It would stand to reason, then (in support of Brazo's research), that texts featuring the above masculine archetypes would resonate with black males students who have experiences and backgrounds similar to the OGs. The table below outlines of archetypes of masculinity outlined by Brazo that also resonated with the research participants:

\begin{tabular}{|l|l|} 
Table 11 \\
Congruence Between Brozo and the OGs \\
\hline Archetype of Masculinity & Examples from Research Study \\
\hline Healer & Malcolm X - revolutionary human rights advocate \\
\hline King & $\begin{array}{l}\text { Edward Swinney - principal who empowered students to } \\
\text { reach their full potential }\end{array}$ \\
\hline Lover & $\begin{array}{l}\text { Ron Dons - teacher and coach who showed vulnerability } \\
\text { and concern for marginalized students }\end{array}$ \\
\hline Patriarch & $\begin{array}{l}\text { Brother Aziz - Was a role model and encouraged } \\
\text { participant to reconsider commitment to athletics over } \\
\text { servant leadership }\end{array}$ \\
\hline Pilgrim & $\begin{array}{l}\text { Howard Thurman - Connected faith with social justice } \\
\text { activism }\end{array}$ \\
\hline Prophet & $\begin{array}{l}\text { Louis Farrakhan - Morally unwavering in advocacy for } \\
\text { black empowerment and independence }\end{array}$ \\
\hline Warrior & $\begin{array}{l}\text { Brother Gregory X - Martial arts master who integrated } \\
\text { morals into martial arts instruction }\end{array}$ \\
\hline Wildman & $\begin{array}{l}\text { Ab - Masculinity partially defined by having "hos" (i.e. } \\
\text { women to be used primarily for sexual satisfaction) }\end{array}$ \\
\hline
\end{tabular}

There are other archetypes of masculinity not mentioned by Brozo but that surfaced in the research. As an additive to Brozo's research, this research offers one other archetype of black masculinity that may be used to engage black males through empowering, enabling literacy instruction. The best description for the archetype of masculinity is the outsider. Several of the OGs talked about feelings of being a persona non grata in specific environments. For example, Don (Focus group interview, January 
25,2013 ) explicitly stated that his predominantly white high school - which he described as "a celebration of whiteness" - left him confused about his place in the world as a black male. Sam talked about being one of two blacks in his elementary and middle school years and having only one black male teacher until he got to college. Ty talked very specifically about how his sheltered, more middle-class background and the perception of him being a nerd left him feeling alienated in a community and school environment dominated by hypermasculine, street wise black males. He stated that he "had no place" in hip hop culture (Ty, Focus group interview, January 25, 2013). This sentiment of being alienated by hip hop culture, it should be noted, is present in the research around efforts to integrate hip hop culture into classrooms where black males are present. It makes the case that urban black American males are not a monolithic group and warns us as researchers against making sweeping generalizations.

A subgroup of the outsider contingent is the gay black male. When conversation around black gay males' role in hip hop culture came up in the focus group, several members of the group expressed strong anti-gay sentiments. One of the research participants even referred to "that homosexuality demon" and also stated that, "If you are gay, I step away from you” (Lon, Focus group interview, January 25, 2013). Another research participant, however, pushed back on Lon's statement, suggesting that black gay males are starting to gain more visibility and acceptance in the world of hip hop culture. He identifies Frank Ocean, an openly gay black male and Grammy winning artist, as an exemplar. Nonetheless, despite the presence of a few openly gay black males in popular hip hop culture, at least from the sentiments of the OGs, the group is still an outlier group. This sentiment is also evident in the literature, as a number of writers have 
explored the turmoil and conflict experienced by black males in the hip hop generation (Denizet-Lewis, 2003; McCune, 2008; Venable, 2001. In Denizet-Lewis' research, one gay black male proclaims,

If you're white, you can come out as an openly gay skier or actor or whatever. It might hurt you some, but it's not like if you're black and gay, because it's like you've let down the whole black community, black women, black history, black pride (cited in Denizet-Lewis, 2003, p. 31).

\section{Research Expands Discussion Around Hip Hop Culture's Capital and Challenges}

Toward the goal of providing a deeper understanding of hip hop culture, this research has privileged the voices of black males and has explored hip hop culture by 1) unpacking its cultural capital, 2) identifying ways it contributes to troubling master narratives around black males, 3) and also highlighting its impact on narrowly defining black male masculinity. As shared previously in this research study report, Michael Eric Dyson, author of Holler if You Hear Me, highlights the implication of educators' marginalization of hip hop culture:

Given its universal popularity and troubling effects, hip-hop is vital cultural language that we had all better learn. To ignore its genius, to romanticize its deficits, or to bash it with undiscerning generalities is to risk the opportunity to engage our children about perhaps the most important cultural force in their lives (Dyson, 2001, p. 138).

In an attempt to add a response to Dr. Dyson's insistence that educators learn about hip hop culture, I synthesized the OGs' perspectives around the cultural capital embedded in the world of hip hop. Within the same context, I also summarized thoughts 
about the troubling narratives and shortcomings of hip hop culture-specifically,

mainstream, current expressions of hip hop culture. Since this study provided much detail in a previous section, I will outline the main themes below.

1. Hip hop culture demonstrates the genius of people of color.

2. Hip hop culture provides a means for the disaffected to share their voices and their truths.

3. Hip hop culture provides a counterstory of resistance, persistence and resilience.

4. Hip hop culture has the potential to be a transformational force, but it is not currently meeting its potential.

5. From a critical perspective, mainstream hip hop culture is providing troubling, limited caricatures of black masculinity.

The above section explored and highlighted hip hop culture's assets and challenges - from the vantage point of the OGs in this research study. The assets described above outline aspects of the community cultural capital embedded within hip hop culture. Dominant discourses, typically created by middle and upper class whites, devalue the knowledge and capital of people of color (Yosso, 2005). Tara Yosso (2005), however, argues that marginalized groups possess community cultural capital that must be valued in the education process. This study contributes to the research exploring the cultural capital of one public school's most academically underperforming group: black males - in hope that it might be used to drive antiracist education actions.

\section{Limitations of the Study}

One of the primary limitations of this study is generalizability. Narrative inquiries do not lend themselves to replicability and reliability (Creswell, 2007). Although the 
study participants might have broad intersectionalities (i.e., race, gender, class) that may lend to transferability with others who embrace hip hop culture, there are other aspects that might make them unique as a group. First, all participants have spent the majority of their years in the Midwest. Their counterstories and perspectives may be informed in nuanced ways by the material realities of their regional experiences.

Second, while the counterstories and perspectives might be nuanced along regional lines, they might also across lines of socioeconomic class and schooling experiences. Based on the focus group discussion (along with the researcher's knowledge of the participants), there are pronounced differences in the participants' family economic status when they were in their pre-adult years. For example, Ty's parents were both educators, and he lived a more upper middle class neighborhood, while George grew up in a single parent household in a low income housing complex.

With regard to schooling experiences, there are some differences as well that make generalizability challenging. While Sam, Ab, LT, and Don went to predominantly white high schools, the other research participants graduated from high schools that were predominantly black. Also, while most participants went to majority white colleges, only Todd went to a historically black college, or HBCU. Last, another element that contributes to the challenge of generalizability is post-undergraduate experience. While Ab, Todd and LT do not have advanced degrees, the rest of the participants do. The researcher contends that all of the aforementioned factors - nuances around regional experiences, family income, racial makeup of K-12 schools and college attendance - all contribute to the limitations of this study. 


\section{Recommendations for Further Study}

To extend and deepen research around the intersections of schooling, hip hop culture and people of color, this research study makes the following recommendations:

1. Continue to explore the cultural capital embedded within broader cross-sections of the hip hop community and use the findings to drive culturally responsive pedagogical efforts.

2. Use the current research to inform the further development of antiracist best practices.

3. With regard to culturally responsive pedagogies, this research should specifically be used to inform hip hop based education (HHBE) pedagogies.

4. Use this research to further build upon and extend counter narratives around black males in the hip hop generation.

5. Continue to explore the relationship between hip hop culture and the further marginalization of perceived outlier groups, like gay black males and high academic achievers.

6. Research around ways to engage black boys through enabling text should consider broadening the archetypes of masculinity to include the outlier archetypes.

7. Compare the schooling experiences of heterosexual black males in the hip hop generation to their gay counterparts.

8. Compare the schooling experiences of black males to their female counterparts.

\section{Conclusion}

The research questions guiding this study are as follows:

1. What are some of the schooling experiences of black men in the hip hop generation? 
2. As a cultural force germane to the lives of many students of color, how has hip hop culture influenced the educated cadre of the OGs of the hip hop generation?

3. In what ways do black men in the hip hop generation represent a counter narrative to the dominant narrative of U.S. schooling experiences and outcomes for black men?

4. In what ways do these same men contribute to the master narrative around black male in the hip hop generation - in either mindset or action?

Last, in the context of the study - literature review, presentation of findings and interpretation of findings - the research questions were explored with considerable depth. The intersections of black males discourses, hip hop culture and schooling are themes evident throughout the research findings and subsequent discussion. Also, in alignment with the education-centric iteration of the Critical Race Theory framework (Solorzano \& Yosso, 2002) this study (a) contextualized the experiences and (b) privileged the cultural capital of students of color. In addition, this research challenged cultural deficit narratives by using counterstorytelling, a recommended strategy for sharing the stories of marginalized groups (Solorzano \& Yosso, 2002). Using the composite counterstory methodology, this research creates a narrative by fusing multiple stories and perspectives into a composite counterstory. Counterstories such as this can give marginalized populations (like black males) hope that they can persist through similarly challenging circumstances (Solorzano \& Yosso, 2002). 


\section{REFERENCES}

2 Live Crew. 1989. Move somethin'. Liberty City, FL: Luke Records

Abe, D. (2009). Hip-hop and the academic canon. Education, Citizenship and Social Justice. (4)3, 263-272.

Admin (2013, April 26). Scarface rips current state of hip hop, blames record execs for turning the industry white. Retrieved April 20, 2013, from http://www.rapbasement.com/scarface/042613-scarface-rips-current-state-of-hiphop-blames-record-execs-for-turning-the-industry-white.html.

Akbar, N. (1984). Chains and images of psychological slavery. Jersey City, N.J: New Mind Productions.

Akom, A. A. (2009). Critical hip hop pedagogy as a form of liberatory praxis. Equity \& Excellence in Education, 41(1), 52-66.

Alexander, B. (2004). Number of black men in college dwindle. Race and Ethnicity on NBC.com. Retrieved August 21, 2011, from http://www.msnbc.msn.com/id/3919177/ns/us_news-life/t/number-black-mencollege-dwindle/.

Alim, H.S. (2007). Critical hip hop pedagogies: combat, consciousness, and the cultural politics of communication. Journal of Language, Identity, and Education, 6(2), $161-176$.

Allen, R. L. (1969). Black awakening in capitalist America: An analytic history. Garden City, N.Y.: Doubleday

Allwood, M. (2012). Russell Simmons reports on progress on Hip-Hop Summit. Retrieved July 25, 2012, from: 
http://www.hsan.org/media/PDF/oldPressReleases/R_Simmons.pdf.

Alvesson, M., \& Skoldberg, K. (1999). Reflexive methodology: Interpretation and research. Thousand Oaks, Calif: SAG

Apple, M. W. (1979). Ideology and curriculum. London: Routledge \& K. Paul.

Baber, C. (1987). The artistry and artifice of Black communication. In Expressively Black: Cultural Basis of Ethnic Identity, edited by Geneva Gay and Willie L. Baber, pp. 75-108. New York: Praeger.

Baker, H.A. J. (1993). Black studies: Rap, and the Academy. Chicago: University of Chicago Press.

Banks, D. (2011). Say word!: Voices from hip hop theater: An anthology. Ann Arbor: University of Michigan Press.

Basu, D., \& Lemelle, S. J. (2006). The vinyl ain't final: Hip hop and the globalization of black popular culture. London: Pluto.

Baszile, D.T. (2009). Deal with it we must: education, social justice, and the curriculum of hip hop culture. Equity and Excellence in Education, 42(1), 6-19.

Bell, D., Delgado, R., \& Stefancic, J. (2005). The Derrick Bell reader. New York: New York University Press.

Bennett, L. (1969). Before the Mayflower; a history of black America. Chicago: Johnson Publishing Company

Berkshire, T. (1988, November 30). Most distressed small city in America. St. Louis Post-Dispatch.

Bernal, M. (1987). Black Athena: The Afroasiatic roots of classical civilization. New Brunswick, N.J: Rutgers University Press. 
Bey, Y., Prez, D., and Mikeflo (2012). Made you die. Retrieved on April 7, 2013 from http://www.youtube.com/watch?v=WcmUAG210oM

Bourdieu, P. \& Passeron, J.C. (1977). Reproduction in Education, Society and Culture. Beverly Hills, CA: Sage.

Bragg, M., Shaw, S., \& Horin, R. (n.d.). Voices of rap: Looking for the perfect beat.

Bridger, S. (2011). How hip hop changed the world. London, England: Fresh One Productions.

Brown, K. (2006). Leadership for social justice and equity: Evaluating a transformative framework and andragogy. Educational Administration Quarterly, 42(5), 700-745.

Brown, L.M. and Gilligan, C. (1992). Meeting at the crossroads: women's psychology and girls' development. Cambridge, MA: Harvard University Press.

Brozo, W. G. (2002). To be a boy, to be a reader: engaging teen and preteen boys in active literacy. Newark, Del: International Reading Association.

Chapman, T. K., \& Hobbel, N. (2010). Social justice pedagogy across the curriculum: The practice of freedom. New York: Routledge

Chapman, T. K., \& Hobbel, N. (2006). Routing the pipeline: The structural dilemmas of urban education. Journal of Urban Learning, Teaching, and Research. 3(2),116129.

Children's Defense Fund (2009). The State of America's Children. The Children's Defense Fund Leave No Child Behind. Retrieved August 27, 2011, from http://www.childrensdefense.org/child-research-data-publications

Clandinin, D. J., and Connelly, F. M. (2000). Narrative inquiry: experience and story in qualitative research. San Francisco: Jossey-Bass Publishers. 
Clay, A. (2003). All I need is one mic: Mobilizing youth for social change in the postcivil rights era. Social Justice. 33(2), 105-121.

Cohen, C. J., Celestine-Michener, J., Holmes, C., Merseth, J. L., \& Ralph, L. (2007) The attitudes and behavior of young Black Americans: Research summary. University of Chicago: Ford Foundation.

Hill, C. P. (2006). From Black power to hip hop: Racism, nationalism, and feminism. Philadelphia: Temple University Press.

Creswell, J.W. (2007). Qualitative inquiry and research design: Choosing among five Approaches, Thousand Oaks, CA: Sage Publications

Davis, T. (1994). The artist in society. Keynote address delivered at the NEA Conference, Chicago, April 14, 1994.

Def, M. (1999). Fear not of man. On Black on Black Sides. Raw Records. New York, NY: Rawkus Records.

Delgado, R. (1995). Critical race theory: The cutting edge. Philadelphia, PA: Temple University Press.

Delgado, R. \& Stefancic, J. (2012). Critical Race Theory: An Introduction (2nd ed.). New York: NYU Press.

Denzin, N. K., \& Lincoln, Y. S. (1994). Handbook of qualitative research. Thousand Oaks: Sage Publications.

Denizet-Lewis, B. (2003). Double lives on the down low. New York Times Magazine, pp 8-28. Retrieved on April 7, 2013, from http://search.proquest.com/docview/215479027?accountid=14576

Dimitriadis, G. (2001). Performing identify/performing text: Hip hop as text, pedagogy, 
and lived practice. New York: Peter Lang.

Diplomas Count (2009). Behind high school, before baccalaureate: meaningful alternatives to a four-year degree. Education Week, 30(34). Retrieved August 21, 2011, from http://www.edweek.org/ew/articles/2011/06/09/34analysis.h30.html?intc=ml

DuBois, W.E.B. (1994). The soul of black folks. Mineola, NY: Dover Publications, Inc.

Duncan-Andrade, J., \& Morrell, E. (2000). Using Hip-Hop Culture as a Bridge to Canonical Poetry Texts in an Urban Secondary English Class.

Dyson, M. E. (2001). Holler if you hear me: Searching for Tupac Shakur. New York: Basic Civitas Books.

Fanon, F. (1967). Black skin, white masks. New York: Grove Press.

Farley, C., (1999). Hip hop nation. Time. 153 (5), 5-27.

Films for the Humanities \& Sciences (Firm), Films Media Group., \& Digital Classics (Firm). (2005). Rap: Looking for the perfect beat. New York, N.Y: Films Media Group. Foster, W. P. (2004). The Decline of the Local: A Challenge to Educational Leadership. Educational Administration Quarterly, 40( 2), 176-191.

Freidrichs, C., Woodman, B., Freidrichs, J., Henry, J., Balcom, B., Carver, S., Unicorn Stencil (Firm), ... Missouri History Museum. (2012). The Pruitt-Igoe myth. New York: First Run Features.

Freire, P. (1970). Pedagogy of the oppressed. New York: Continuum.

Gay, G. (2000). Culturally responsive teaching: Theory, research, and practice. New York: Teachers College Press.

George, N. (1998). Hip hop America. New York: Viking. 
Genovese, E. D. (1974). Roll, Jordan, roll: The world the slaves made. New York:

Pantheon Books.

Giroux, H. A. (2001). Theory and resistance in education: Towards a pedagogy for the opposition. Westport, Conn: Bergin \& Garvey.

Grandmaster, F., \& Furious Five (Musical group). (2002). The message. Track 1: Sugar Hill.

Greenburg, Z.O. (2012). The Forbes five: Hip-hop's wealthiest artists in 2012. Forbes. Retrieved July 25, 2012 from: http://www.forbes.com/sites/zackomalleygreenburg/2012/04/17/the-forbes-fivehip-hop-wealthiest-artists-2012/

Hager, S. (1984). Hip-hop: The illustrated history of break dancing, rap music, and graffiti. New York: St. Martin's Press.

Haycock, K. (2001). Helping all students achieve. Educational Leadership, 58(6), 15-35.

Harrison, P.M. \& Beck A.J. (2004). Prisoners in 2004: Bureau of justice statistics bulletin. October 2005.

Herrnstein, R. J., \& Murray, C. A. (1994). The bell curve: Intelligence and class structure in American life. New York: Free Press.

Hill, M.L. (2009). Beats, rhymes, and classroom life: hip-hop pedagogy, and the politics of identity. English Journal, 96(2), 23-27.

Hill, M.L. (2009). Wounded healing: forming a storytelling community in hip-hop lit. The Teachers College Record, 111(293), 1-42.

Hill, N. (1966). Think and grow rich. No. Hollywood, Calif: Melvin Powers, Wilshire Book Co. 
Hollie, S. (2001). Acknowledging the language of African American students: Instructional strategies. The English Journal, 90(4), 54-59.

Horsford, S. D., Grosland, T., \& Gunn, K. M. (2011). Pedagogy of the personal and professional: Toward a framework for culturally relevant leadership. Journal of School Leadership. 21( 4), 582-606.

Intellect, W. (2009). Panel discussion at the Nation of Islam hip hop summit. Intellect,W. Retrieved on October 1, 2012 from http://www.youtube.com/watch?v=jybwj0ai6ZE

Irby, D. J., \& Hall, H. B. (March 01, 2011). Fresh faces, new places: Moving beyond teacher-researcher perspectives in hip-hop-based education research. Urban Education, (46)2, 216-240.

Irby, D.J. (2006). Do the knowledge: A standards-based hip hop learning guide. Philadelphia: Art Sanctuary. Retrieved July 28, 2012, from: http://artsanctuary.org/wp-content/uploads/2011/12/Do-The-Knowledge-AStandards-Based-Hip-Hop-Learning-Guide-Updated-11-06.pdf Irizarry, J.G. (2009). Representin': Drawing from hip-hop culture and urban youth to inform teacher education. Education and Urban Society, 41(4), 489-515.

Jay Z (2010). The hits collection: Volume one. New York, NY: Def Jam/Roc Nation.

King, M. L. (1963). Letter from Birmingham city jail. Philadelphia: American Friends Service Committee.

Kitwana, B. (2002). The hip hop generation: Young blacks and the crisis in African American Culture. New York, NY: Basic Civitas Books.

Kitwana, B. (2005). Why white kids love hip-hop: Wankstas, wiggers, wannabes, and the new reality of race in America. New York, NY: Basic Civitas Books. 
Keyes, C.L (2009). At the crossroads: Rap music and its African nexus.

Ethnomusicology, 40(2), 223-248.

Kobin, C., \& Tyson, E. (January 01, 2006). Thematic analysis of hip-hop music: Can hiphop in therapy facilitate empathic connections when working with clients in urban settings? The Arts in Psychotherapy. 33 (4), 343-356.

Kohlberg, L. (1981). Essays on moral development. San Francisco: Harper \& Row.

Kozol, J. (1991). Savage inequalities: Children in America's schools. New York: Crown Publishers.

Krueger, R. A., \& Casey, M. A. (2000). Focus groups: A practical guide for applied research. Thousand Oaks, Calif: Sage Publications.

Kunjufu, J. (1982). Countering the conspiracy to destroy Black boys. Chicago: Afro-Am Publishing Company.

Ladson-Billings, G.J.(1997). The dreamkeepers: Successful teachers of AfricanAmerican children. San Francisco, CA: Jossey-Bass.

Ladson-Billings, G., \& Tate, W. F. I. V. (1995). Toward a critical race theory of education. Teachers College Record. 97 (1), 47-68.

Ladson-Billings, G. (1998). Preparing teachers for diverse student populations: a critical race theory perspective, Review of Research in Education, 24, 211-247.

Ladson-Billings, G. (2001). Crossing over to Canaan: the journey of new teachers in diverse classrooms. San Francisco: Jossey-Bass.

Lane-Poole, S., \& Gilman, A. (1888). The Moors in Spain. London: T. Fisher Unwin. Lawrence, S. M. and Tatum, B. D. (1997). Teachers in transition: The impact of antiracist 
professional development on classroom Practice. Teachers College Record. 99 (1), 162-78.

Lee, J. (1998). State policy correlates of the achievement gap among racial and social groups. Studies in Educational Evaluation, 24(1), 137-152.

Lee, E. (1985). Letters to Marcia: a teacher's guide to anti-racist education. Toronto, Ont: Cross Cultural Communication Centre.

Lincoln, Y. (1993). I and though: Method, voice, and roles in research with the silenced. In D. McLaughlin \& W. Tierney (Eds.), Naming Silenced Lives. Boston: Routledge Kegan Paul.

Low, B. E. (2010). The tale of the talent night rap: Hip-hop culture in schools and the challenge of interpretation. Urban Education, (45) 2, 194-220

Majors, R., \& Billson, J. M. (1992). The cool pose: The dilemmas of black manhood in America. New York: Lexington Books.

Mason, J. (1996) Qualitative researching. London: Sage.

Matsuda, C. (1991). Voices of America: Accent, antidiscrimination law, and a jurisprudence for the last reconstruction. Yale Law Journal. 100, 1329-1407.

McBride, J., \& Harvey, D. A. (2007). Hip-Hop Planet: Whether you trace it to New York's South Bronx or the villages of West Africa, hip-hop has become the voice of a generation demanding to be heard. National Geographic, (211)4, 100-119.

McCune, J. Q. J. (2008). “Out” in the club: The down low, hip-hop, and the architexture of black Masculinity. Text and Performance Quarterly, (28)3, 298314. 
Melucci, A. (1999). Challenging codes: Collective action in the information age.

Cambridge: Cambridge University Press.

Merriam, S. B., \& Merriam, S. B. (1998). Qualitative research and case study applications in education. San Francisco: Jossey-Bass Publishers.

Mertens, D.M. (2005). Research and evaluation in education and psychology:

Integrating diversity with quantitative, qualitative, and mixed methods. Thousand Oaks, CA: Sage Publications.

Michaels, L. (2012). Mitt Romney campaign cold open. Saturday Night Live. April 7, 2012. New York, NY.

Miles, M. \& Huberman, A. (1994). Qualitative Data Analysis (2 ${ }^{\text {nd }}$ edition). Thousand Oaks, CA: Sage Publications

Mitchell, T. (2001). Global noise: Rap and hip-hop outside the USA. Middletown, Conn: Wesleyan University Press

Montagu, A. (1964). Man's most dangerous myth: The fallacy of race. Cleveland: World Publishing Company

Morrell, E., \& Duncan-Andrade, J. M. R. (2002). Promoting academic literacy with urban youth through engaging hip-hop culture. English Journal, (91) 6, 88-92.

Mos, D. (1999). Black on both sides. New York: Rawkus.

Nas. 1996. It was written. New York, NY: Columbia.

National Center for Educational Studies (2012). Digest of education statistics. Retrieved July 23, 2012, from the National Center for Educational Studies Web site: http://nces.ed.gov/programs/digest/. 
National Center for Education Statistics \& United States Office of Educational Research and Improvement (2009). Grade 12 reading and mathematics 2009 national and pilot state test results. Retrieved on August 21, 2011 from http://nces.ed.gov/nationsreportcard/pdf/main2009/2011455.pdf.

National Hip Hop Summit. (2012). Mission statement. (2012). Retrieved July 25, 2012, from: http://hsan.org/content/main.aspx?pageid=7

National Hip Hop Summit. (2012). What we want. 2012. Retrieved July 25, 2012, from: http://hsan.org/content/main.aspx?pageid=27

Nieto, S. (2010). Language, culture, and teaching: Critical perspectives. New York: Routledge.

$\mathrm{Ni}^{* *}$ as With Attitude (1998). F*ck the police. On Straight Outta Compton [CD]. Los Angeles, CA. Ruthless/Priority/EMI Records.

Nowlan, J. (1989, May 14). No obstetric services. St. Louis Post-Dispatch.

Ogbar, J. O. (2007). Hip-hop revolution: The culture and politics of rap. Lawrence: University Press of Kansas.

Ogbu, J. U. (2008). Minority status, oppositional culture, and schooling. New York: Routledge.

Ogbu, J.U. (1992). Understanding cultural diversity and learning. Educational Researcher. 21(8), 5-37.

Ollerenshaw, J. A., and Creswell, J.W. (2002). Narrative research: A comparison of two restorying data analysis approaches. Qualitative Inquiry. 8 (3): 329-347.

Oware, M. (2009). A “man’s woman”?: Contradictory messages in the songs of female rappers, 1992-2000. Journal of Black Studies, (39), 786-802. 
Petchauer, E. (2009). Framing and reviewing hip-hop educational research. Review Of Educational Research, 79(2), 946-978.

Powell, K. (2001). Hip-hop is the most important youth culture on the planet. Time. Retrieved July 25, 2012 from: http://www.time.com/time/arts/article/0,8599,55624,00.html\#ixzz21fGV13op

Ridenour, C. \& and Steiner, E. (2000). Delivering a message: Chuck D. Retrieved on July 25, 2012 from: http://www.cosmik.com/aa-march00/chuck_d.html.

Rodriguez, L.F. (2009). Dialoguing, cultural capital, and student engagement: toward a hip hop pedagogy in the high school and university classroom. Equity and Excellence in Education, 42(1), 20-35.

Rogers, J. A. (1968). From "superman" to man. New York, N.Y: Helga M. Rogers. Rose, S. (2010). Breaking news: Total sales of Jay Z's Decoded - 54, 983. Retrieved on May 1, 2013 from http://sandrarose.com/2010/12/breaking-news-total-sales-ofjay-zs-decoded-54983/

Rose, T. (1994). Black noise: Rap music and black culture in contemporary America. Hanover, NH: University Press of New England.

Rossi, P. H., Lipsey, M. W., \& Freeman, H. E. (2004). Evaluation: A Systematic Approach ( $\left.7^{\text {th }} e d.\right)$. Thousand Oaks, CA: Sage.

Schott Foundation for Public Education (2010). Yes We Can: The Schott 50 State Report on Public Education and Black Males. Schott Foundation for Public Education. Cambridge, MA. Retrieved August 21, 2011, from www.nyccej.org/wpcontent/uploads/2010/08/bbreport1.pdf 
Scott-Heron, G., \& Jackson, B. (2009). The best of Gil Scott Heron. London: Sony Music.

Shacklock, G., \& Smyth, J. (1998). Being reflexive in critical educational and social research. London: Falmer Press.

Smith, W. A., Yosso, T. J., \& Solorzano, D. G. (2007). Racial primes and black misandry on historically white campuses: Toward critical race accountability in educational administration. Educational Administration Quarterly, 43(5), 559-585.

Shor, I. (1992). Empowering education: Critical teaching for social change. Chicago: University of Chicago Press.

Solórzano, D. (1997). Images and words that wound: critical race theory, racial stereotyping and teacher education. Teacher Education Quarterly, 24, 5-19

Solorzano, D and Yosso, T (2001). Critical race and method: counter-storytelling: Chicana and Chicano graduate school experiences. Teacher Education Quarterly 14(4), 471-495.

Solórzano, D. \& Yosso, T. (2002) Critical race methodology: Counter-storytelling as an analytical framework for education research. Qualitative Inquiry, 69(1/2), 23-44.

State Superintendent \& Chairman of Board - Illinois Board of Education (1898, April 20). State superintendent and board chairman cited. St. Louis Post-Dispatch.

Stinson, D. W. (2008). Negotiating sociocultural discourses: The counter-storytelling of academically (and mathematically) successful African American male students. American Educational Research Journal, 45(4), 975-1010.

Stovall, D. (2006). We can relate: hip-hop culture, critical pedagogy, and the secondary classroom. Urban Education, 41(6), 585-602. 
Tatum, A. W. (2005). Teaching reading to black adolescent males: Closing the achievement gap. Portland, ME: Stenhouse Publishers.

Tatum, A.W. (2009). Reading and resilience. Reading into Practice, 1(1), 1-9.

Tatum, A. W. (n.d.). Enabling texts that matter. Retrieved on April 7, 2013 from http://www.ngsp.net/Portals/0/Downloads/HBNETDownloads/Edge_Mono_Tatm 1.pdf

Tatum, B. (1997). Why Are all the black kids sitting together in the cafeteria?: And other conversations about race. New York, NY: Basic Books.

Thurman, H. (1949). Jesus and the disinherited. New York: Abingdon-Cokesbury Press.

Toogood, P., Ice-T, ., Baybutt, A., Afrika, B., Eminem, ., Nas, ., JolyGoodFilms (Firm), ...Vivendi Entertainment (Firm). (2012). Something from nothing: The art of rap. Universal City, CA: Distributed by Vivendi Entertainment.

Tylier-Ameen, D. (2011). Gil Scott-Heron, poet and musician, has died. NPR Music.

Retrieved on April 7, 2013, from

http://www.npr.org/blogs/therecord/2011/05/27/136731274/gil-scott-heron-poetand-musician-has-died

Unknown. (1989, April 2). Sewage problems, chemicals, lead poisoning, contamination. St. Louis Post-Dispatch.

Unknown. (1988, May 22). Health and hospital statistics, food expenditures, underimmunization, homicide rate. St. Louis Post-Dispatch.

Unknown. (1989, April 28). State superintendent and chairman of state board cited (1989). St. Louis Post-Dispatch.

Unknown. (2013). Beliefs of the Universal Zulu Nation. Retrieved on April 7, 2013, from http://www.zulunation.com/beliefs.html 
Urban Prep Academies (2013). Class of 2012. Retrieved April 7, 2013 from http://www.urbanprep.org/about/100-percent/class-2012

Villegas, A. M., \& Lucas, T. (2002). Educating culturally responsive teachers: A coherent approach. Albany: State University of New York Press.

Watts, R. J., Abdul-Adil, J. K., \& Pratt, T. (2002). Enhancing critical consciousness in young African American men: A psychoeducational approach. Psychology of Men and Masculinity. 3 (1), 41-50.

Wheeler, E. (1991). Most of my heroes don't appear on no stamps: The dialogics of rap music. Journal of Black Music Research. 11(2), 191-226.

Williams, G. (1986). The black disc jockey as a cultural hero. Popular Music and Society. 10(3), 79-90.

Williams, A.D. (2007). The critical cultural cipher: hip-hop's role in engaging students in a discourse of enlightenment. Dissertation Abstracts International, 68(8). (UMI No. 3260489).

Woodson, C. G. (1990). The mis-education of the Negro. Trenton, NJ: Africa World Press.

Woodson, J. (2008). Hip hop under corporate control. The Final Call, Retrieved April 7, 2013 from http://www.finalcall.com/artman/publish/Entertainment_News_5

Yosso, Tara J. (2005). Whose culture has capital? A Critical Race Theory discussion of community cultural wealth. Race Ethnicity and Education, 8(1), 69-91. 


\title{
APPENDIX A. INVITATION TO PARTICIPATE IN THE RESEARCH
}

\author{
Dear Prospective Research Study Participant:
}

As a black male member of the hip hop generation who has persisted through high school and navigated to post-secondary education, your voice and personal stories may be informative to educators as they continue to develop theories and practices that can inform culturally responsive educational leadership. You have persevered through both pre-K through 12 public education and through post -secondary education. This places you in a category with less than $30 \%$ of your adult black male peers in the hip hop generation, especially those growing up in America's urban centers.

I would like to invite you to participate in a research study entitled, "Hip Hop Culture, Education and Black Males: Learning Lessons from Hip Hop's OGs." The purpose of this research is to explore the schooling experiences of black males in the hip hop generation, like yourself. Hip hop culture has been one of the most impactful cultural forces over the last 30 years, and this research will explore ways that the voices of members of the hip hop generation might help educators develop culturally responsive practices that will positively impact the educational and personal growth of black male youth.

Participants in this research study will engage in an approximately 90-minute focus group interview with a small group of black males who also self-identify as being members of the hip hop generation. The discussion would be held at a location and time most convenient for all participants. Should you choose to participate, you will be informed of your rights as a participant and asked to sign a written consent form. The consent form is attached for your review.

If you would be willing to participate in this small focus group, please reply to me, Ian P. Buchanan, at ipb0ed@mail.missouri.edu. Should you have any questions, please contact me at 314.302.6028. I thank you in advance for considering the invitation.

Sincerely,

Ian Buchanan

University of Missouri

Doctoral Student 


\section{APPENDIX B. CONSENT FORM \\ Consent Form \\ Research Study of Men in the Hip-Hop Generation}

You are invited to take part in a study of the experiences of black men in the hip-hop generation. I am conducting this research as part of my doctorate in Educational Leadership from the University of Missouri. I believe that members of the hip-hop generation have stories to tell that would help educators adopt more relevant approaches to teaching young black men. The purpose this research is to explore the schooling experiences of black men in the hip hop generation and how those experiences might inform culturally relevant educational leadership practices.

Participation in this research requires your informed, written consent. Please read the following information very carefully so that you understand the process.

\section{What does participation mean?}

- If you volunteer to participate, you will meet for about three hours with a small group of men who self-identify as being a part of the hip-hop generation. We will meet in a quiet, private location. Responses to the focus group questions will be audio recorded.

- Your name will not appear on any materials I collect. A code or pseudonym will be used to identify the recording and the written transcript of the recording.

- When findings of the focus group are reported, your quotations will not be identifiable. Findings from all focus group participants will be combined into general themes.

- Remember, you do not have to participate; this is strictly voluntary. You do not have to answer a focus group question if you choose not to do so. You can withdraw from participating at any time and all information that you provided will be destroyed.

Note: According to federal guidelines, the researcher must securely maintain copies of all pertinent information from the study, including the audio recordings and copies of this written consent form, for a period of seven (7) years from the date of completion of the study.

If you have any further questions, you can contact my advisor Dr. Peggy Placier (573) 882-9643, placierp@missouri.edu) at the University of Missouri-Columbia.

If you have any concerns about your rights as a research participant, you can call the office at the University of Missouri-Columbia that approved this study: MU Institutional Review Board, (573) 882-9585. 


\section{Consent Form:}

I have read this information and agree to allow Ian Buchanan to perform the procedures referred to above, and to report and publish his findings.

Participant's Signature

Date

Researcher's Signature

Date 


\title{
APPENDIX C. FOCUS GROUP INTERVIEW QUESTION GUIDE
}

\author{
Interview Question Guide \\ Ian P. Buchanan \\ Research Study - University of Missouri
}

\begin{tabular}{|c|c|}
\hline Categories & $\begin{array}{l}\text { General Question } \\
\text { - Follow up questions }\end{array}$ \\
\hline Introduction & 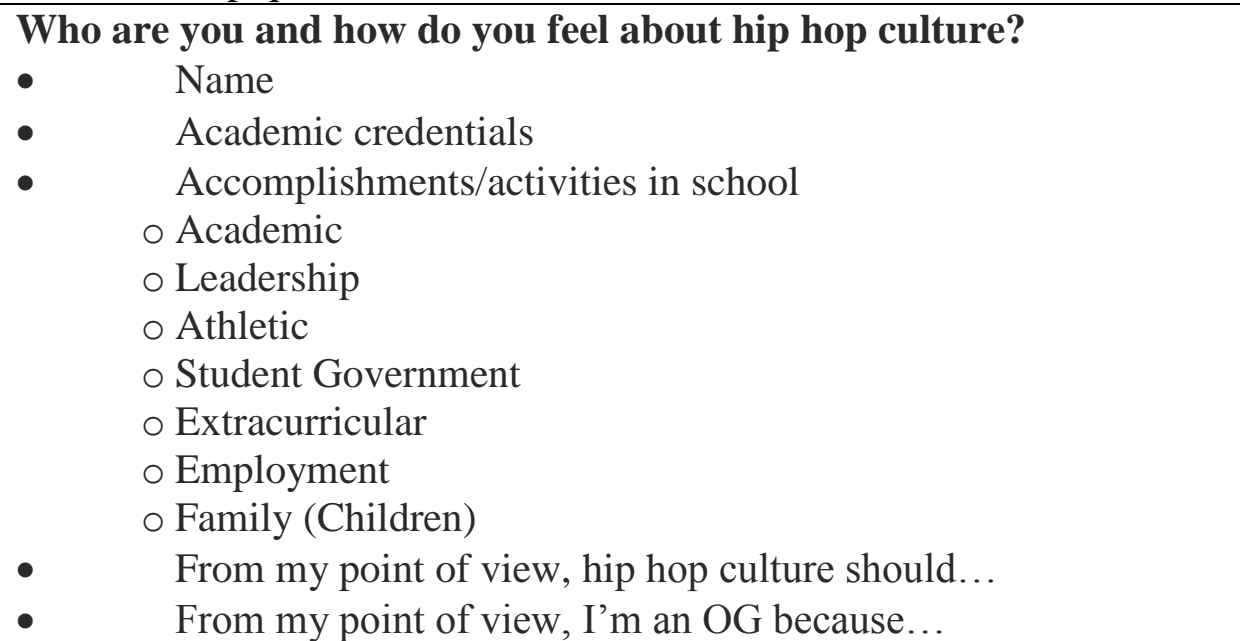 \\
\hline $\begin{array}{l}\text { Positive } \\
\text { Schooling } \\
\text { Experiences }\end{array}$ & $\begin{array}{l}\text { What were your positive schooling experiences? } \\
\text { How did your pre-college educational experiences (K-12, along } \\
\text { with additional supports like INROADS, College Bound, etc.) } \\
\text { prepare (or undeprepare) you for college? What, if anything, was } \\
\text { missing from your experience? } \\
\text { In your entire educational experiences, who were the three } \\
\text { teachers, administrators, and/or schools that most positively impacted } \\
\text { you? Who changed the game for you? Is there a particular experience } \\
\text { or story that exemplifies the impact? } \\
\text { Was there any particular black male educator that influenced } \\
\text { - } \quad \text { Wou? } \quad \text { As a college student? } \\
\text { - } \quad \text { As a post-college adult? } \\
\text { life? } \\
\text { If you could recommend a book for a high schooler or college } \\
\text { - Can you think of a time when an educator helped to build your } \\
\text { - } \quad \text { Itudent to read, what would it be? } \\
\text { confidence? What did they say or do? } \\
\text { How well did your college experience prepare you for what } \\
\text { you are currently doing professionally? } \\
\text { and/or activities that consisted mostly of black males (or blacks in }\end{array}$ \\
\hline
\end{tabular}




\begin{tabular}{|c|c|}
\hline & general)? How was that helpful for you? \\
\hline $\begin{array}{l}\text { Challenging } \\
\text { School } \\
\text { Experiences }\end{array}$ & $\begin{array}{l}\text { What challenges did you experience as you navigated through } \\
\text { school? } \\
\text { - What was one of the major challenges you had to overcome in } \\
\text { - } \quad \text { achool? How did you overcome it? What supports were helpful? } \\
\text { If you were to give an } 8^{\text {th }} \text { grade black male one piece of advice } \\
\text { about being successful (despite the odds) in school, what would you } \\
\text { tell him? } \\
\text { What schooling challenges did you have because you are a } \\
\text { black male? } \\
\text { Can you think of a time in your school experience when you } \\
\text { - } \quad \text { thought you were treated unfairly because you were a black male? } \\
\text { How did being underprepared for college impact you? } \\
\text { Did most of your college peers share your cultural } \\
\text { background? } \\
\text { Was there ever a time when you overstepped some of your } \\
\text { own ethical bounds? What were the circumstances? } \\
\text { Was there ever a time when you "sold out" in order to progress } \\
\text { in school? What were the circumstances? } \\
\text { Did faith play a role in helping you navigate challenges? }\end{array}$ \\
\hline $\begin{array}{l}\text { Hip hop } \\
\text { culture }\end{array}$ & $\begin{array}{l}\text { What are some of the ways hip hop culture has inspired, challenged, } \\
\text { disappointed, embarassed or educated you? Is hip hop culture an } \\
\text { asset or liability to black males' empowerment? } \\
\text { - Who were the most conscious artists/groups of your day? } \\
\text { - } \quad \text { From my point of view as a what is good about } \\
\text { - } \quad \text { hip hop culture is... } \\
\text { From my point of view as a } \\
\text { - } \quad \text { Whcerning, troubling, damaging, negative about hip hop culture is... } \\
\text { What is one of your most memorable hip hop experiences? } \\
\text { If you could have dinner with } 3 \text { of hip hop culture's greatest, } \\
\text { - } \text { who would it be, and why? } \\
\text { What does it mean to be a man in hip hop culture? How do } \\
\text { - } \quad \text { What's up with homosexuality in hip hop culture? } \\
\text { Should hip hop culture play a more prominent role in educating } \\
\text { black boys? If so, explain. }\end{array}$ \\
\hline
\end{tabular}


Ian Pettis Buchanan was born in East St. Louis, Illinois and attended East St. Louis Lincoln High School, East St. Louis, Illinois. In 1987, he entered the University of Missouri-Columbia in Columbia, Missouri. In 1992, Ian graduated from the university with a degree of Bachelor of Science in Industrial Engineering. During the following years, he was employed as an educator, serving students in elementary, middle and high schools. He taught mathematics for five years and served as a principal for more than a decade. He currently works for Teach For America. In June of 2009, he entered the Graduate School at University of Missouri-Columbia 